\title{
31. EARLY CRETACEOUS MAGNETIC POLARITY TIME SCALE AND THE MAGNETOSTRATIGRAPHY OF DEEP SEA DRILLING PROJECT SITES 603 AND 534, WESTERN CENTRAL ATLANTIC ${ }^{1}$
}

\author{
James G. Ogg, Scripps Institution of Oceanography²
}

\begin{abstract}
Drilling at Sites 534 and 603 of the Deep Sea Drilling Project recovered thick sections of Berriasian through Aptian white limestones to dark gray marls, interbedded with claystone and clastic turbidites. Progressive thermal demagnetization removed a normal-polarity overprint carried by goethite and/or pyrrhotite. The resulting characteristic magnetization is carried predominantly by magnetite. Directions and reliability of characteristic magnetization of each sample were computed by using least squares line-fits of magnetization vectors. The corrected true mean inclinations of the sites suggest that the western North Atlantic underwent approximately $6^{\circ}$ of steady southward motion between the Berriasian and Aptian stages. The patterns of magnetic polarity of the two sites, when plotted on stratigraphic columns of the pelagic sediments without turbidite beds, display a fairly consistent magnetostratigraphy through most of the Hauterivian-Barremian interval, using dinoflagellate and nannofossil events and facies changes in pelagic sediment as controls on the correlations. The composite magnetostratigraphy appears to include most of the features of the M-sequence block model of magnetic anomalies from M1 to M10N (Barremian-Hauterivian) and from M16 to M23 (BerriasianTithonian). The Valanginian magnetostratigraphy of the sites does not exhibit reversed polarity intervals corresponding to M11 to M13 of the M-sequence model; this may be the result of poor magnetization, of a major unrecognized hiatus in the early to middle Valanginian in the western North Atlantic, or of an error in the standard block model. Based on these tentative polarity-zone correlations, the Hauterivian/Barremian boundary occurs in or near the reversed-polarity Chron M7 or M5, depending upon whether the dinoflagellate or nannofossil zonation, respectively, is used; the Valanginian/Hauterivian boundary, as defined by the dinoflagellate zonation, is near reversed-polarity Chron M10N.
\end{abstract}

\section{INTRODUCTION}

Site 603 of Deep Sea Drilling Project Leg 93 was drilled on the lower continental rise $\left(35.3^{\circ} \mathrm{N}, 290.0^{\circ} \mathrm{E}\left[70^{\circ} 01 \mathrm{~W}\right]\right)$, $435 \mathrm{~km}$ east of Cape Hatteras, North Carolina (Fig. 1). Site 534 of DSDP Leg 76 was drilled in the Blake-Bahama Basin $\left(28.3^{\circ} \mathrm{N}, 284.6^{\circ} \mathrm{E}\left[75^{\circ} 23 \mathrm{~W}\right]\right), 870 \mathrm{~km}$ northnortheast of the Bahamas. Thick $(\sim 400 \mathrm{~m})$ sections of Lower Cretaceous pelagic carbonates were continuously cored at each site with good recovery.

Pilot studies performed at Site 534 indicated that the Lower Cretaceous sedimentary rocks would yield weakintensity, stable, characteristic magnetic directions upon thermal demagnetization (Ogg, 1983). These results, and the continuity of the stratigraphic record as indicated by sedimentological and biostratigraphic studies, justified an extensive paleomagnetic sampling of both sites.

The objectives of this project were fourfold: (1) to determine the magnetostratigraphy of each site, (2) to use the magnetostratigraphies to obtain precise correlation of sediment facies between sites, (3) to correlate the magnetostratigraphies to the M-sequence model of marine magnetic anomalies, making it possible to assign biostratigraphic ages to these anomalies, and (4) to obtain stage-by-stage paleolatitudes for each site in order to determine the rate of latitudinal drift of the western North Atlantic from the Tithonian through Aptian.

\footnotetext{
${ }^{1}$ van Hinte, J. E., Wise, S. W., Jr., et al., Init. Repts, DSDP, 93:Washington (U.S. Govt, Printing Office).

2 Present address: Department of Earth and Atmospheric Sciences, Purdue University, West Lafayette, Indiana 47907.
}

\section{PREVIOUS INVESTIGATIONS OF EARLY CRETACEOUS MAGNETOSTRATIGRAPHY}

\section{M-sequence of Marine Magnetic Anomalies}

Patterns of marine magnetic anomalies are generally mathematically modelled by geophysicists as a series of normal and reversely magnetized blocks of oceanic crust. These theoretical block models have been shown to be remarkably similar to the actual polarity patterns obtained through magnetostratigraphy. The numbered magnetic anomalies provide a system of nomenclature for intervals of time ("chrons") represented by corresponding polarity "zones" of magnetostratigraphy of the Late Jurassic through Cenozoic (e.g., notation proposed by Harland et al., 1982, or by LaBrecque et al., 1983; the terminology of magnetic polarity units used here follows the guidelines of IUGS, 1979).

For the Late Jurassic and Early Cretaceous, the current standard scale is the "M-sequence" block model (Fig. 2), which is based on the Hawaiian magnetic lineations created at the ancient spreading center between the Pacific and Farallon plates (summarized in Larson and Hilde, 1975). There are a few nomenclatural inconsistencies resulting from the evolution of the model; for example, M2 and M4 are the only numbered normal-polarity anomalies, and $\mathrm{M} 10 \mathrm{~N}$ is a reversed-polarity anomaly (named for F. Naugler) inserted between M10 and M11. Portions of this block model have been correlated to the magnetic anomalies of other spreading centers in the Pacific; however, only the Hawaiian lineations exhibit the complete sequence from M0 to M25 (or even M1 through M17) on a single strip of ocean crust bound 


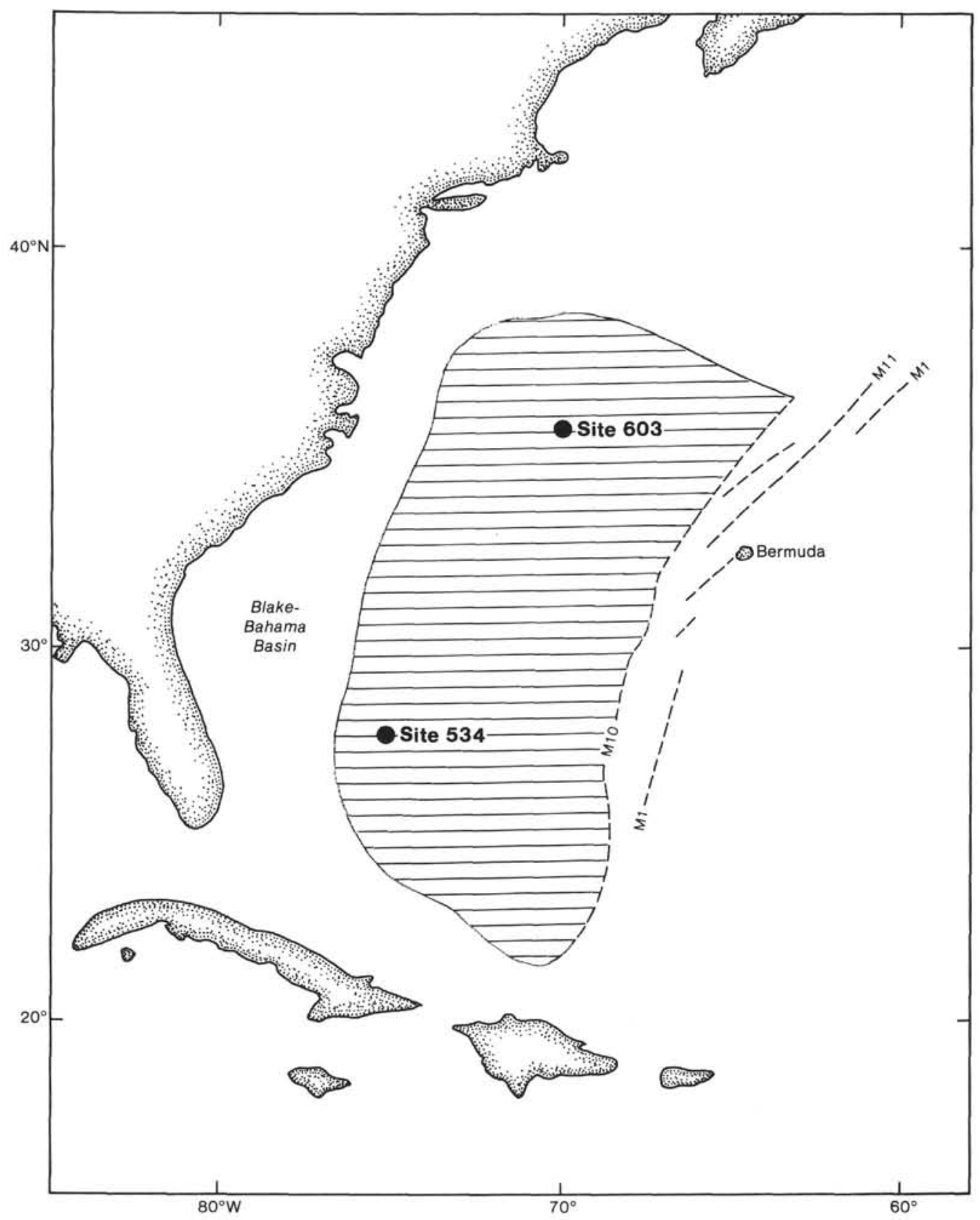

Figure 1. Location of Site 534 and Site 603 in the western central Atlantic. Horizontal shading indicates regional extent of seismic reflector $\beta$ (from Jansa et al., 1979), generally interpreted as the top of the Lower Cretaceous Blake-Bahama Formation. (Modified after Robertson and Bliefnick, 1983.) Dashed lines show magnetic anomalies.

by fracture zones. The M-sequence model has the implicit assumption that there were no ridge jumps, changes in spreading rate, or other complications for the approximately 40 m.y. represented by the set of Hawaiian magnetic lineations.

An independently derived magnetic anomaly pattern in the western North Atlantic, the "Keathley sequence" (Vogt et al., 1971), has less detail owing to the relatively slower spreading rate. The Hawaiian M-sequence adequately models the pre-M15 and post-M5 portions of this pattern (Larson and Pitman, 1972; Larson and Hilde, 1975; Vogt and Einwich, 1979). The inability to corre- late M5 through M14 to the Atlantic pattern led Vogt and Einwich (1979) to suggest that Hawaiian anomalies M5 through M10N could not be resolved as individual features in the Atlantic and that M13 and M14 could barely be resolved. Based on later detailed complications of the magnetic anomalies, Schouten and Klitgord (1977, 1982; Klitgord and Schouten, in press) proposed that M10 through M5 are absent in the North Atlantic because spreading ceased for that 5-6-m.y. interval.

These difficulties in correlating the Hawaiian magnetic lineations to the Atlantic magnetic anomaly pattern suggest that perhaps the M-sequence block model 


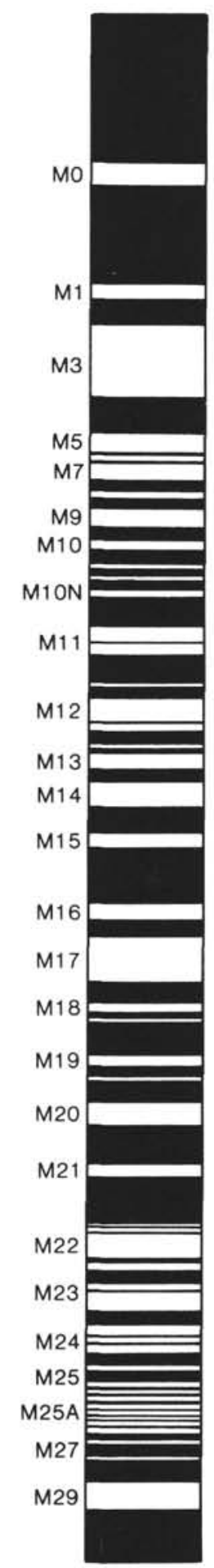

Figure 2. M-sequence block model of the Hawaiian magnetic anomaly lineations. Reversed-polarity blocks are indicated in white; the numbered major blocks of reversed polarity constitute the standard for nomenclature of polarity chrons. (Modified from Harland et al., 1982.)

is not perfect; it may possibly incorporate the duplication of some anomalies caused by minor spreading-ridge jumps, especially in the interval between M15 and M5.

Age estimates for a few of the M-sequence magnetic anomalies have been obtained from DSDP sites (Table
1). These age estimates are based on nannofossil or foraminifer assemblages in the basal sediments overlying basalt, and may have a greater uncertainty in zonal assignment than reported. The DSDP sites enabled direct dating of the M-sequence magnetic anomalies and provided the first framework of the magnetic polarity time scale (e.g., Larson and Hilde, 1975; van Hinte, 1976a,b).

\section{Early Cretaceous Magnetostratigraphy}

Magnetostratigraphy of pelagic sediments in DSDP cores or exposed on land has made possible the assignment of biostratigraphic ages to corresponding polarity zones. Recent studies have correlated approximately half of the M-sequence polarity zones to various faunal and floral zonations; the results of the main studies on the Early Cretaceous (M0 through M19) are presented in Table 2 . This data set has provided the main framework for recent compilations of the M-sequence magnetic polarity time scale (e.g., Kent and Gradstein, 1985; Lowrie and Ogg, 1986), although the precision of these ages has not been examined.

\section{Standard Biostratigraphic Zones}

The main limitations and sources of apparent discrepancy between these studies are the use of different faunal and floral groups, of different zonations within these groups, and different assignments of these zones to standard geologic stages. Only in a few cases are the actual correlations to the M-sequence questionable (e.g., an alternative interpretation of the data of Cirilli et al., 1984 , is possible). In Table 2, the biostratigraphic zone and inferred geologic stage as originally published in the studies are followed by a "standard" zonation for that faunal/floral group and its "standard" correlation to geologic stages. In this manner, some degree of uniformity is established, at least within a faunal/floral group (nannofossils, calpionellids, etc.).

For nannofossil zonations, the arbitrarily selected "standard" scale is the "NC" zonation, which has been used for Cretaceous sediments recovered at several Atlantic DSDP sites. The conversion of other nannofossil zonations to the NC system is according to Roth (1978, his fig. 2), and the corresponding geologic stage assign-

Table 1. Basal sediment ages, DSDP sites drilled on magnetic anomalies.

\begin{tabular}{|c|c|c|c|c|}
\hline Anomaly $^{\mathrm{a}}$ & Ocean & Age & Site & References \\
\hline M0 & Atlantic & $\begin{array}{c}\text { early to late } \\
\text { Aptian }\end{array}$ & 417,418 & Donnelly et al., 1980 \\
\hline "J" & Atlantic & late Barremian & 384 & Tucholke et al., 1979 \\
\hline M4 & Pacific & Prob. Hauterivian & 303 & Larson et al., 1975 \\
\hline M8n & Pacific & $\begin{array}{l}\text { late Hauterivian- } \\
\text { early Aptian }\end{array}$ & 166 & Winterer et al., 1973 \\
\hline M9 & Pacific & Prob. Hauterivian & 304 & Larson et al., 1975 \\
\hline M16n & Atlantic & $\begin{array}{l}\text { early Valanginian- } \\
\text { late Berriasian }\end{array}$ & 387 & $\begin{array}{l}\text { Tucholke et al., } 1979 \\
\text { Okada and } \\
\text { Thierstein, } 1979\end{array}$ \\
\hline $\begin{array}{l}\text { between } \\
\text { M25-M24 }\end{array}$ & Atlantic & Oxfordian & 105 & $\begin{array}{l}\text { Hollister et al., } 1972 \\
\text { Larson and } \\
\text { Hilde, } 1975\end{array}$ \\
\hline
\end{tabular}
$\mathrm{a}_{\mathrm{n}}=$ the normal-polarity anomaly younger than the numbered reversed-polarity
anomaly. 
Table 2. Early Cretaceous magnetostratigraphy: previous studies with polarity-zone correlations to M-sequence.

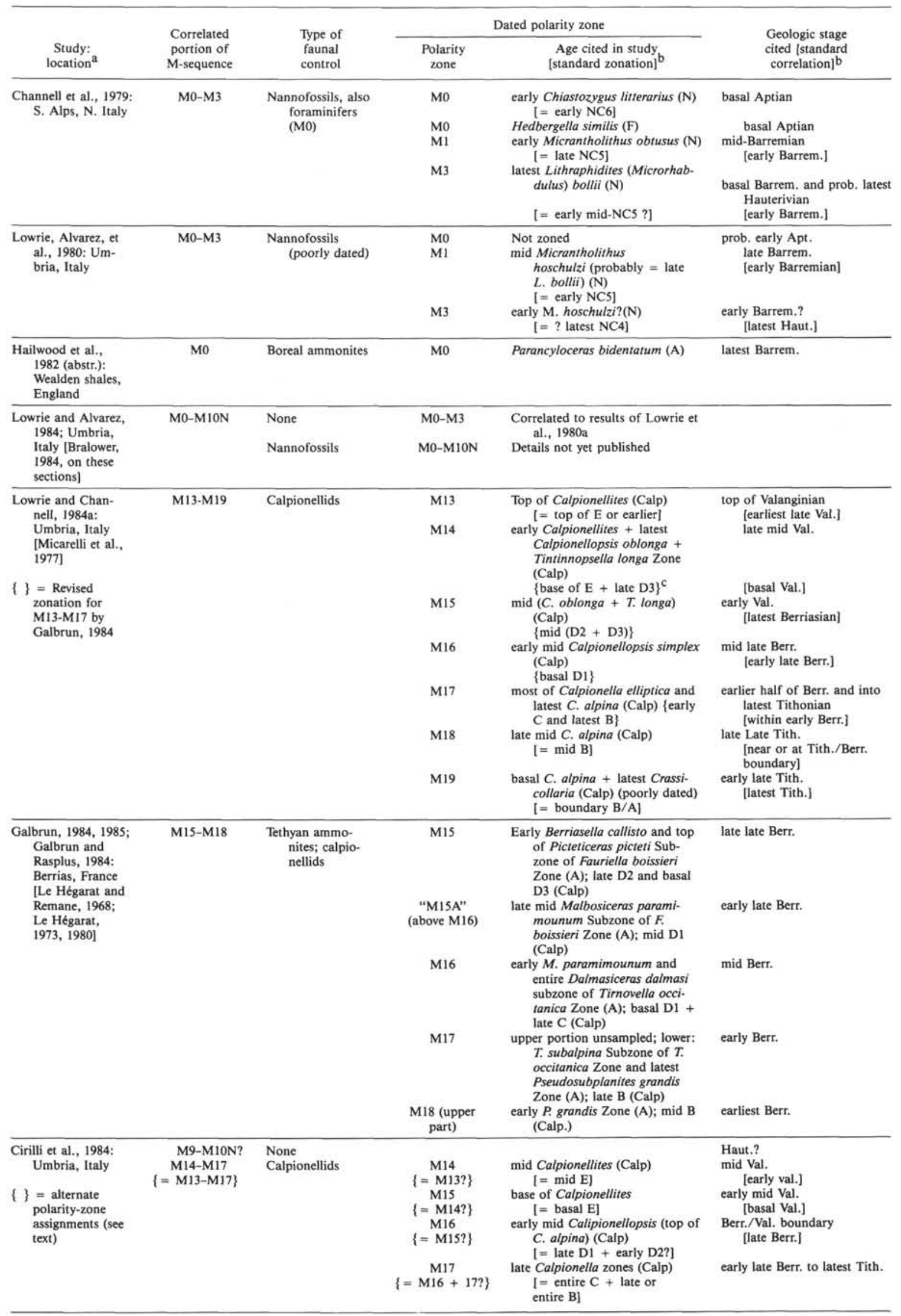


Table 2 (continued).

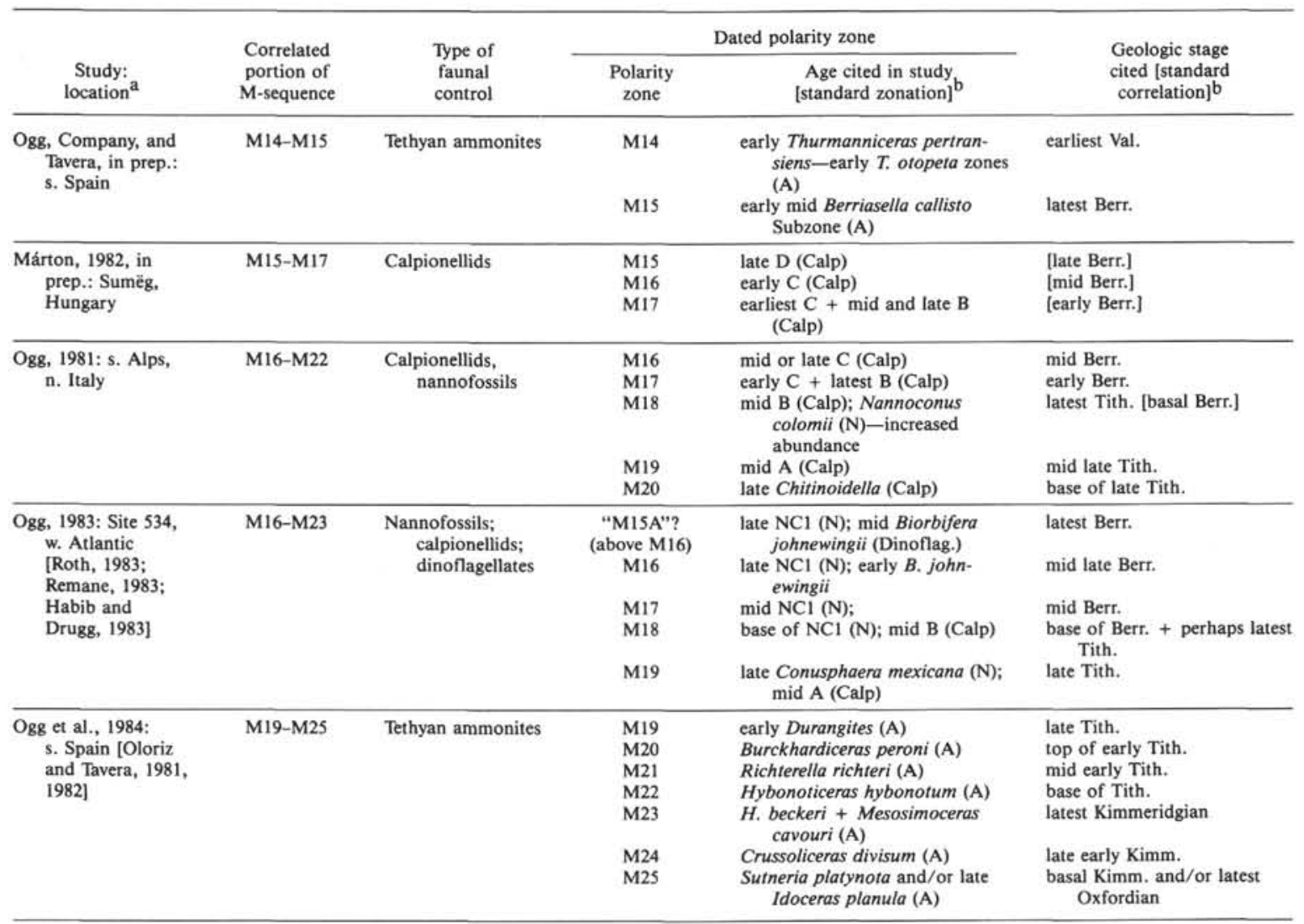

a Paleontology reference in square brackets.

b Standard zones and geologic stage correlations are: Nannofossils $(\mathrm{N})$ : NC notation and zonal correlations after Roth, 1978. Geologic stage correlations after Roth, 1983. Calpionellids (Calp): A, B, C, D, E notation and zonal correlations after Allemann et al., 1971, and Remane, 1978. Geologic stage correlations after Remane, 1978, and Zeiss, 1983. $\mathrm{F}=$ foraminifers. $\mathrm{A}=$ ammonites.

ments are from Roth (1983). For nannofossil biostratigraphy, it would be preferable to put the appearance or extinction datum of key index species in the stratigraphic columns, but unfortunately none of the magnetostratigraphic studies has included such range data.

For calpionellid biostratigraphy, the selected standard scale is the "standard calpionellid zonation" of Allemann et al. $(1971,1975)$ with its A,B,C,D,E subdivision notation by Remane (1978). The corresponding geologic stage assignments follow Remane (1978) and Zeiss (1983).

This standardization within a faunal group does not mean that the converted zones can be blindly compared, however. The assignment of a zone to an assemblage of species is often a subjective interpretation which varies among paleontologists (e.g., how elongate must the calpionellid Calpionella alpina become before it is classified as its descendant $C$. elliptica?) and is dependent upon the preservation of key index species. The assignment of each standard zonation to the Early Cretaceous geologic stages, as defined in stratotype or parastratotype sedimentary outcrops, is an active area of controversy and research. Therefore, the "late Hauterivian" of the current NC nannofossil zonation is probably not entirely coeval with the "late Hauterivian" of the current dinoflagellate zonation.

\section{Ages of Polarity Chrons}

M0 through M3 have been identified in several sections (Channell et al., 1979; Lowrie, Alvarez, et al., 1980; Lowrie, Channell, et al., 1980; Lowrie and Alvarez, 1984). Reversed-polarity Chron M0 is either at or very near the Barremian/Aptian boundary; M1 is in the late Berriasian; and M3 is probably in the early Berriasian.

The pattern of M4 through M10N has been recognized in a study by Lowrie and Alvarez (1984), but the nannofossil biostratigraphy of these sections (Bralower, 1984; pers. comm., 1985) has not yet been published. M11 and M12 have not been identified in any magnetostratigraphic section. M13 is tentatively assigned an age of earliest late Valanginian (latest calpionellid Zone E) based on a magnetostratigraphic section by Lowrie and Channell (1984a), although the sampling detail and magnetic polarity data are poor.

The Berriasian/Valanginian boundary occurs between M14 and M15 (Galbrun, 1984, 1985). An apparent discrepancy between the published ages for M14 through M16 (Galbrun, 1984, 1985; Galbrun and Rasplus, 1984; Lowrie and Channell, 1984a; Ogg, Company, and Tavera, in prep.) is resolved when the different calpionellid zo- 
nations are converted to the standard. The ages of M15 through M18 are tied to ammonite zones and subzones of the Berriasian stratotype (Galbrun, 1984, 1985; Galbrun and Rasplus, 1984).

A standard international definition for the Jurassic/ Cretaceous boundary (= Tithonian/Berriasian boundary) is not yet available; therefore, it has been proposed that the "base of Chron M18" be established as the international definition for this system boundary (Ogg, 1984; Lowrie and Channell, 1984b; Lowrie and Alvarez, 1984; Ogg and Steiner, 1985; Ogg and Lowrie, 1986). M19 through M24 are correlated to ammonite zones in southern Spain (Ogg et al., 1984), and M25 is at or near the Oxfordian/Kimmeridgian boundary.

The main remaining uncertainty in the accurate dating of the M-sequence is the interval from M4 through M12, and improved ages are desired for M1 to M3 and for M13. The results presented here from Sites 534 and 603 enable partial dating of M5 through M10N.

\section{Magnetostratigraphy of Lower Cretaceous DSDP Sediments}

There have been exploratory or preliminary magnetostratigraphic studies at nearly every DSDP site at which Lower Cretaceous sediments have been recovered. Some of the more extensive studies in Atlantic facies are listed in Table 3. None of these studies yielded a detailed, thereby correlatable, magnetic polarity sequence for any preAptian Lower Cretaceous stage. The reasons for the lack of success vary for each site and include sporadic recovery, highly condensed stratigraphy or hiatuses, extremely weak or unstable magnetization, inability of the demagnetization procedures (generally only alternating-field ["AF"] treatment) to remove magnetic overprints, poor biostratigraphic control, and inadequate density of sampling. There are also the problems inherent in using only inclination to define polarity and the general lack of a second, continuous section with similar facies and biostratigraphy to demonstrate that the results are reproducible. In the present study, most of these factors have been eliminated by the fortuitous availability of two sites with extraordinarily good recovery of thick, continuous, well-dated Lower Cretaceous sections, by the dense sampling, by the partial declination control at Site 603 , and by the use of more accurate measurements

Table 3. Magnetostratigraphic studies of Lower Cretaceous DSDP sediments of the Atlantic.

\begin{tabular}{lll}
\hline \multicolumn{1}{c}{ Site } & \multicolumn{1}{c}{ Age span } & \multicolumn{1}{c}{ Reference } \\
\hline 105 & Kimm.-Val. & Steiner, 1977 \\
$361,363,364$ & Apt.-Alb. & Keating and Helsley, 1978a \\
367 & Oxf.-Val. & Kent and Lan, 1978 \\
369 & Apt.-Alb. & Keating and Helsley, 1987b \\
386 & Barrem.-Alb. & Keating and Helsley, 1979 \\
$391 \mathrm{C}$ & Kimm.-Barrem. & Keating and Helsley, 1978c \\
397 & Haut. (NC4) & Hamilton, 1979 \\
398 & Barrem.-Alb. & Morgan, 1979 \\
400,402 & Apt.-Alb. & Hailwood, 1979 \\
417 & Aptian & Kelts and Giovanoli, 1980 \\
$534 \mathrm{~A}$ & Kimm.-Berr. & Ogg, 1983 \\
& (pilot Val.-Apt.) & \\
\hline
\end{tabular}

than in any previous study, coupled with new, computerized analysis procedures for each sample.

\section{LITHOSTRATIGRAPHY AND BIOSTRATIGRAPHY}

\section{Lithostratigraphy and Pelagic Facies}

The Berriasian through Barremian pelagic sediment facies recovered at Sites 534 and 603 consists primarily of white, bioturbated limestone and gray, laminated marl. This facies occurs throughout the western North Atlantic and has been designated the "Tithonian-Neocomian White and Grey Limestones" by Lancelot et al. (1972) or the "Blake-Bahama Formation" by Jansa et al. (1979). The detailed stratigraphic columns of Sites 534 and 603 are presented in the respective site chapters (Sheridan, Gradstein, et al., 1983; Site 603 chapter, this volume), an extensive facies analysis of the Early Cretaceous of Site 534 is given by Robertson and Bliefnick (1983), and corresponding facies summaries of Site 603 are presented in Sarti and von Rad (this volume) and by Ogg et al. (this volume). The sedimentation history at Sites 534 and 603 is briefly summarized here, with an emphasis on the factors important for magnetostratigraphy.

During the latest Tithonian, there was a major increase in the rate of carbonate sedimentation, with consequent rapid burial of organic components. The increase in carbonate content and the establishment of a postdepositional, mildly reducing environment resulted in a gradual change from Tithonian reddish marl to Berriasian white limestone and in a corresponding change in the carrier of characteristic magnetization from hematite to magnetite (Ogg et al., 1983). Pyrite occurs abundantly within the Lower Cretaceous facies as small nodules or laminae, as partial replacements of radiolarian tests, and as dispersed specks.

Two main pelagic lithologies, white, bioturbated limestone and gray, laminated, marly limestone, occur in variable proportions throughout the Valanginian, Hauterivian, and Barremian, and are commonly in a quasicyclic relationship. The upper Berriasian through Aptian pelagic sediment column may be subdivided into 10 or 11 subunits by using the relative proportions of light-colored, bioturbated limestone to darker, laminated marly limestone and by using the types of cycle development (Ogg et al., this volume). Most of these pelagic-sediment subunits are present at both sites; they appear to be coeval within the resolution of dinoflagellate biostratigraphy (Table 4). This lithostratigraphic framework serves as a guide in correlating the magnetic polarity columns of these two sites.

At the end of the Barremian, a transition occurs to the overlying organic-matter-rich claystones of the midCretaceous "black shale" or "Hatteras Formation." At Site 603, this "black claystone" facies includes an interval of varicolored reddish to greenish, bioturbated claystone within the Albian (lithologic Unit IV C) in which hematite reappears as the carrier of characteristic magnetization.

Interspersed within the pelagic sediments are numerous turbidites of two main types: (1) dark gray, organic- 
Table 4. Lithologic subunits of pelagic sediments, Lower Cretaceous, DSDP Sites 603 and 534.

\begin{tabular}{|c|c|c|c|c|}
\hline \multirow[b]{2}{*}{ Subunit } & \multirow[b]{2}{*}{ Description $^{\mathrm{a}}$} & \multicolumn{2}{|c|}{ Interval (cores) } & \multirow[b]{2}{*}{ Age } \\
\hline & & Hole $603 \mathrm{~B}$ & Hole $534 \mathrm{~A}$ & \\
\hline A & $\begin{array}{l}\text { B dominant, with } \mathrm{B} / \mathrm{BL} \\
\text { alternations }\end{array}$ & 82 -mid 80 & $\begin{array}{c}\text { Uncertain if present, } \\
\text { maybe } 83-84\end{array}$ & Latest Berr. \\
\hline B & Primarily L: & & & \\
\hline B1 & L dominant & $\begin{array}{l}\text { Mid 80-lower } \\
78\end{array}$ & $\begin{array}{l}\text { Uppermost } 82 \text {-mid } \\
\quad 78\end{array}$ & Earliest Val. \\
\hline B2 & $\begin{array}{l}\text { B/L cycles (narrow } \\
\text { interval) }\end{array}$ & $\begin{array}{l}\text { Lower 78-top } \\
77\end{array}$ & Mid 78-mid 77 & early Val. \\
\hline B3 & L dominant & $\begin{array}{c}\text { Base } 76 \text {-lower } \\
74\end{array}$ & Mid 77-mid 74 & late Val. \\
\hline c & Cycles: & & & \\
\hline $\mathrm{C} 1$ & $\begin{array}{l}\text { B/L cycles well-devel- } \\
\text { oped }\end{array}$ & $\begin{array}{l}\text { Lower } 74- \\
\text { upper } 62\end{array}$ & Mid 74-mid 64 & $\begin{array}{l}\text { Latest Val.- } \\
\text { e. Haut. }\end{array}$ \\
\hline $\mathrm{C} 2$ & $\begin{array}{l}\text { BL/L cycles, less well- } \\
\text { developed }\end{array}$ & $\begin{array}{l}\text { Upper 62-top } \\
58\end{array}$ & $\begin{aligned} \text { Mid } & 64-58 \text { [Core } 57 \\
& =\text { gap] }\end{aligned}$ & $\begin{array}{c}\text { late Haut., } \\
\text { Maybe } \\
\text { basal } \\
\text { Barrem. }\end{array}$ \\
\hline${ }^{\mathrm{D}} \mathrm{DI}$ & L dominant: & $57-55$ & & \\
\hline D2 & $\begin{array}{l}\text { BL-B-L to highest } \\
\text { well-developed B }\end{array}$ & $54-51-2$ & $53-51 ?$ & $\begin{array}{l}\text { mid and late } \\
\text { Barrem. }\end{array}$ \\
\hline D3 & L. (cycles of light/dark) & $51-2-45 ?$ & $50-48$ & $\begin{array}{l}\text { I. Barrem., } \\
\text { basal } \\
\text { Aptian }\end{array}$ \\
\hline D4 & $\begin{array}{l}\text { L/BL to highest } B \text { or } \\
\text { BL bed }\end{array}$ & ? Missing ? & $\begin{array}{l}47-45-3 ; \text { (minor BL } \\
\text { at } 45-1)\end{array}$ & Aptian \\
\hline DS & Dark L & Basal 44-44-1 & Upper 45 -lower 44 & Aptian \\
\hline
\end{tabular}

a Subunits are distinguished according to the dominant structures: $\mathrm{B}=$ bioturbated light-colored limestone; $\mathrm{L}=$ laminated darker-colored marly limestone; $\mathrm{BL}=$ intermediate (laminated with minor bioturbation); $\mathrm{B} / \mathrm{L}=$ alternations of $\mathrm{B}$ and $\mathrm{L}$ structures; $\mathrm{L} / \mathrm{BL}=$ alternating $\mathrm{L}$ and BL, etc. Ages are according to the dinoflagellate biostratigraphy of the sites.

matter-rich, claystone turbidites occurring from the early Valanginian to Aptian, and (2) an influx of siltstone and sandstone turbidites characterizing the Hauterivian and Barremian. At Site 603, this coarse clastic influx reaches a peak in the Barremian; at Site 534, the influx peaks during the Hauterivian. These turbidite episodes drastically alter the sedimentation rates of the sediment column, hence the magnetostratigraphic patterns.

There are two major hiatuses present in the Lower Cretaceous. At Site 534, an hiatus of uppermost Barremian to basal Valanginian sediments is indicated by a sudden change in facies (approximately Core 534A-82), a prominent regional reflector $\mathrm{C}^{\prime}$, (Sheridan, Gradstein et al., 1983; Sheridan et al., 1983), and the presence of a sharp Berriasian/Valanginian paleontological boundary (Roth, 1983; Habib and Drugg, 1983). No basal Valanginian hiatus was identified at Site 603. Both sites have indications of a basal Aptian hiatus where a major change of facies is the cause of the major regional reflector, $\beta$ (Sheridan et al., 1983; Tucholke, 1981). At Site 534, sampling was not continued above this facies change. At Site 603 , it is possible that most of the upper Barremian and lower Aptian is absent.

\section{Biostratigraphy}

Age control in the Lower Cretaceous sediments is primarily by nannofossil and dinoflagellate biostratigraphies with minor support from other microfossil (foraminifer and calpionellid) assemblages. The foraminifer and calpionellid paleontologies are summarized in the site chapters of both sites (both by M. Moullade) and by Gradstein (1983) and Remane (1983), respectively. The dinoflagellate biostratigraphy has been partially correlated to stratotypes and parastratotypes of European Tethyan stages and was determined for both sites by the same paleontologists (Habib and Drugg, 1983, and this volume).
Being based primarily on the first occurrence of index species, it should be relatively unaffected by redeposition.

The nannofossil biostratigraphy of both sites is based on the first and last occurrences of several index species whose ranges have been partially correlated to European Tethys stratotype and parastratotype sections (Thierstein, 1973; Roth, 1978, 1983; Bralower, 1984, and pers. comm., 1985). The nannofossil events used to correlate Sites 603 and 534 are identified with varying reliability and precision: "In my experience, the base of Tubodiscus verenae (base of zone NC3) and the top of Cruciellipsis cuvillieri (base of NC5) are very reliable; the top of $T$. verenae (base of NC4) and the base and top of Diadorhombus rectus are not too reliable, as the former becomes less typical near the top of its range, and the latter is too susceptible to dissolution; Chiastozygus litterarius (base of NC6) is easily confused with similar species and is also delicate and easily dissolved or recrystallized; and Rucinolithus wisei and Speetonia colligata are rare and thus have spotty apparent ranges" (P. Roth, pers. comm., 1985). The abundant redeposited beds in the upper portion of the Lower Cretaceous at each site may have resulted in an upward displacement of the last occurrences of some of these index species. The nannofossil biostratigraphy was analyzed by different paleontologists for each site - Roth (1983) for Site 534 and Covington and Wise (this volume) for Site 603-which could introduce different observer bias in identifying some of the more fragile or rare species. These difficulties in the current state of nannofossil biostratigraphic correlation for the Atlantic and the associated differences between age assignments by dinoflagellate and by nannofossil zonation are major problems for tying the magnetostratigraphy to the biostratigraphy of the Early Cretaceous.

\section{SAMPLING AND ANALYTICAL METHOD}

On average, three oriented paleomagnetic minicores $(2.5 \mathrm{~cm}$ in diameter, 2.3 to $2.5 \mathrm{~cm}$ long) were drilled perpendicular to the axis of the split core from each $1.5-\mathrm{m}$ section of recovered sedimentary rock. A total of 436 samples were analyzed from the Berriasian through Barremian portion of Hole 534A (Cores 46-92). A total of 442 samples were analyzed from the upper Berriasian through lower Albian portion of Hole 603B (Cores 40-82).

The coring of the Lower Cretaceous strata of Hole 603B deviated significantly from vertical. A $16.4^{\circ}$ average deviation from vertical was determined from 6 measurements by the downhole Kuster instrument and measurements of the "apparent dip" of laminae in the interval of Cores 41-75 $\left(\right.$ standard deviation $=1.1^{\circ} ; 95 \%$ confidence level $=$ $2.0^{\circ}$ ). By recording the relative orientation of the axis of each minicore relative to the "plunge" direction of the apparent dip of the laminae (arbitrarily set to $0^{\circ}$ ), a control on the declination of these samples with respect to the azimuth of hole deviation was obtained (see Fig. 3). Approximately two-thirds of the Lower Cretaceous samples of Hole 603B could be reliably oriented by this method; the precision of each relative azimuth orientation was about $\pm 20^{\circ}$. This procedure made it possible to use both the inclination and the relative declination of characteristic magnetization for determining the magnetic polarity of the samples. A similar procedure was used by Morgan (1979) at Site 398 and by Ogg (1986) at Site 585 to place relative declination control on samples. The computation of the actual azimuth direction of the deviation of Hole 603B and of the resulting "structural correction" to the mean paleomagnetic inclinations will be discussed later.

The measured deviation of Hole 534A from vertical was less than $1^{\circ}$ through the Lower Cretaceous portion.

All paleomagnetic analyses and demagnetizations were made in a steel-shielded room (internal magnetic field less than 1000 nannotesla 


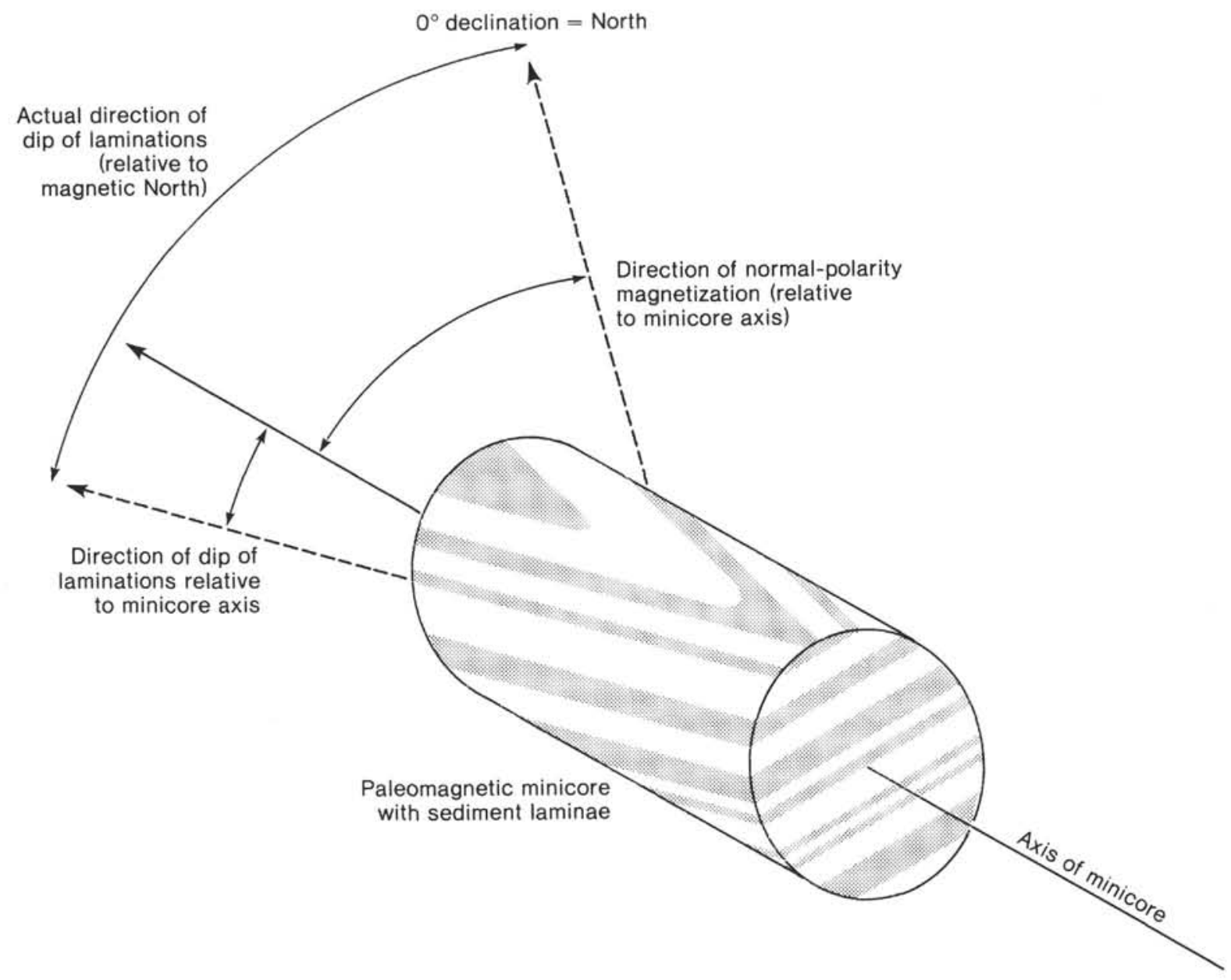

Figure 3. Orientation method for Site 603 minicores using dipping laminae. The azimuth of apparent dip of the laminae relative to the axis of the minicore provides a means to orient each sample with respect to the next. This direction was used as a "field correction" on the sample orientations. The declination of normal-polarity characteristic magnetization in this coordinate system (with respect to the direction of apparent dip) makes it possible to determine the azimuth of the deviation of the DSDP hole from vertical (with respect to paleonorth). This azimuth is then used as a "structural correction" on the direction of characteristic magnetization.

(nT) or $1000 \lambda$ ) at the University of Wyoming. Measurements were made on a computer-linked two-axis ScT cryogenic magnetometer using 8 orientations per sample $\left(90^{\circ}\right.$ rotations about $\mathrm{Z}$-axis in upright and inverted positions). A precision of $5 \times 10^{-12} \mathrm{Am}^{2}\left(5 \times 10^{-9}\right.$ emu) on the total magnetic moment was obtained through the use of 5 one-second-time-averaged measurements at each orientation; this is equivalent to a precision of $5 \times 10^{-7} \mathrm{~A} / \mathrm{m}$ for the typical $10 \mathrm{~cm}^{3}$ minicore $\left(1 \mathrm{~A} / \mathrm{m}=10^{-3} \mathrm{emu} / \mathrm{cm}^{3}\right)$. This highly precise but rather time-consuming procedure was used only for weakly magnetized samples having intensities less than $1 \times 10^{-4} \mathrm{~A} / \mathrm{m}$; more strongly magnetized samples were measured using two 0.1 -second-time-averaged measurements at each orientation. For samples with an intensity of magnetization less than $4 \times 10^{-6} \mathrm{~A} / \mathrm{m}$, the imprecision on the direction of magnetization becomes greater than $25^{\circ}$; such measurements were considered to be an unreliable indicator of the polarity of magnetization.

Except for a dozen pilot samples that were treated by progressive AF demagnetization, all samples were treated by progressive thermal demagnetization in a non-inductively-wound furnace with a separate cooling chamber. Friable samples were enclosed in aluminum foil; I did not attempt to reglue them after each heating step. The thermal demagnetization procedure varied for different lithologies depending upon the results of pilot samples; in general, each sample was measured at a minimum of four demagnetization levels (using $30^{\circ}$ to $50^{\circ} \mathrm{C}$ increments) in addition to the natural remanent magnetization (NRM).

\section{MAGNETIC PROPERTIES}

There are four distinct sample lithologies within the Lower Cretaceous of the two sites, each having different magnetic properties: white limestone (Berriasian), bioturbated white limestone alternating with laminated gray marl to marly limestone (Valanginian-Barremian), clastic turbidite beds (Hauterivian-Barremian), and black to grayish red claystone (Aptian-Albian).

\section{White Limestone (Berriasian)}

Hole 534A, Cores 82-92; not penetrated in Hole 603B.

The magnetic behavior of this lithology (and that of the underlying Tithonian reddish marls) is described in detail in Ogg (1983) and can be summarized as follows. The NRM intensities range from 2 to $7 \times 10^{-4} \mathrm{~A} / \mathrm{m}$; the higher intensities occur toward the base of the unit. NRM directions are dominated by a normal overprint having a mean inclination similar to the present magnetic or dipole field at the site. This normal overprint was easily removed by thermal demagnetization, where- 
as progressive $\mathrm{AF}$ demagnetization had no effect. A comparison between thermal and AF demagnetization on a split sample is shown in Figure 4. The "unblocking" temperature at which this normal overprint was removed changed gradually from about $300^{\circ} \mathrm{C}$ for the lowermost Berriasian to about $200^{\circ} \mathrm{C}$ for the uppermost Berriasian samples. The lower Berriasian samples maintained stable directions from $300^{\circ}$ to $450^{\circ} \mathrm{C}$ (mean intensity $=1$ $\left.\times 10^{-4} \mathrm{~A} / \mathrm{m}\right)$. The upper Berriasian samples had stable directions from $200^{\circ}$ to $300^{\circ} \mathrm{C}$ (mean intensity $=5 \times$ $10^{-5} \mathrm{~A} / \mathrm{m}$ ), and displayed unstable directions and high magnetic viscosity above $350^{\circ}$ or $400^{\circ} \mathrm{C}$. An interpretation of this limited set of magnetic property data is that the secondary overprint is carried by goethite, pyrrhoti- te, and/or oxidized titanomagnetite, and that the primary carrier is magnetite. The high magnetic viscosity and unstable directions obtained at $300^{\circ}-400^{\circ} \mathrm{C}$ are typical of many marine limestones and may be the result either of the dehydration of geothite forming hematite or of the conversion of pyrite to pyrrhotite and magnetite (Lowrie and Heller, 1982).

\section{Bioturbated White Limestone and Laminated Gray Marl (Valanginian-Barremian)}

Hole 534A, Cores 47-81; Hole 603B, Cores 44-82.

This is the dominant pelagic facies of the Lower Cretaceous. The magnetic intensities and demagnetization behavior of both lithologies - bioturbated white lime-
A

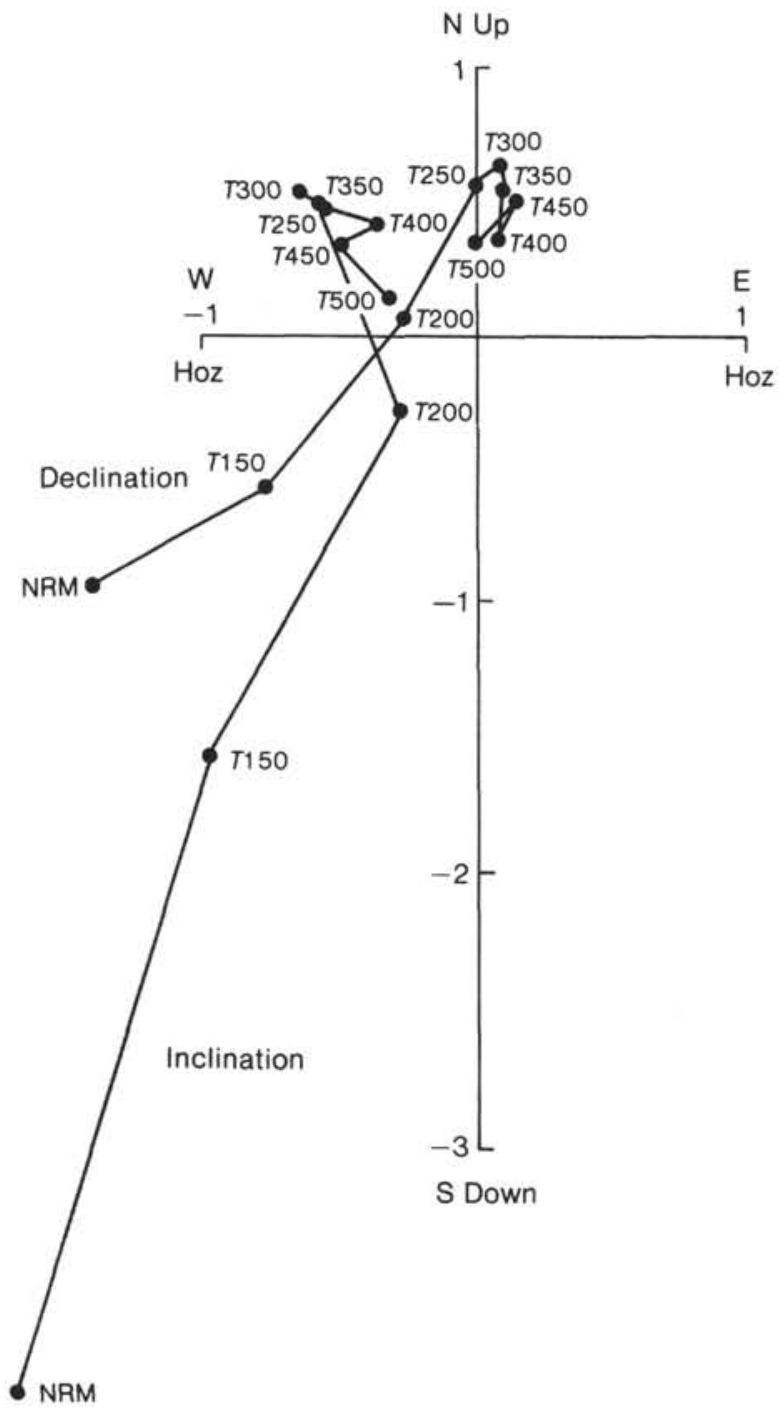

B

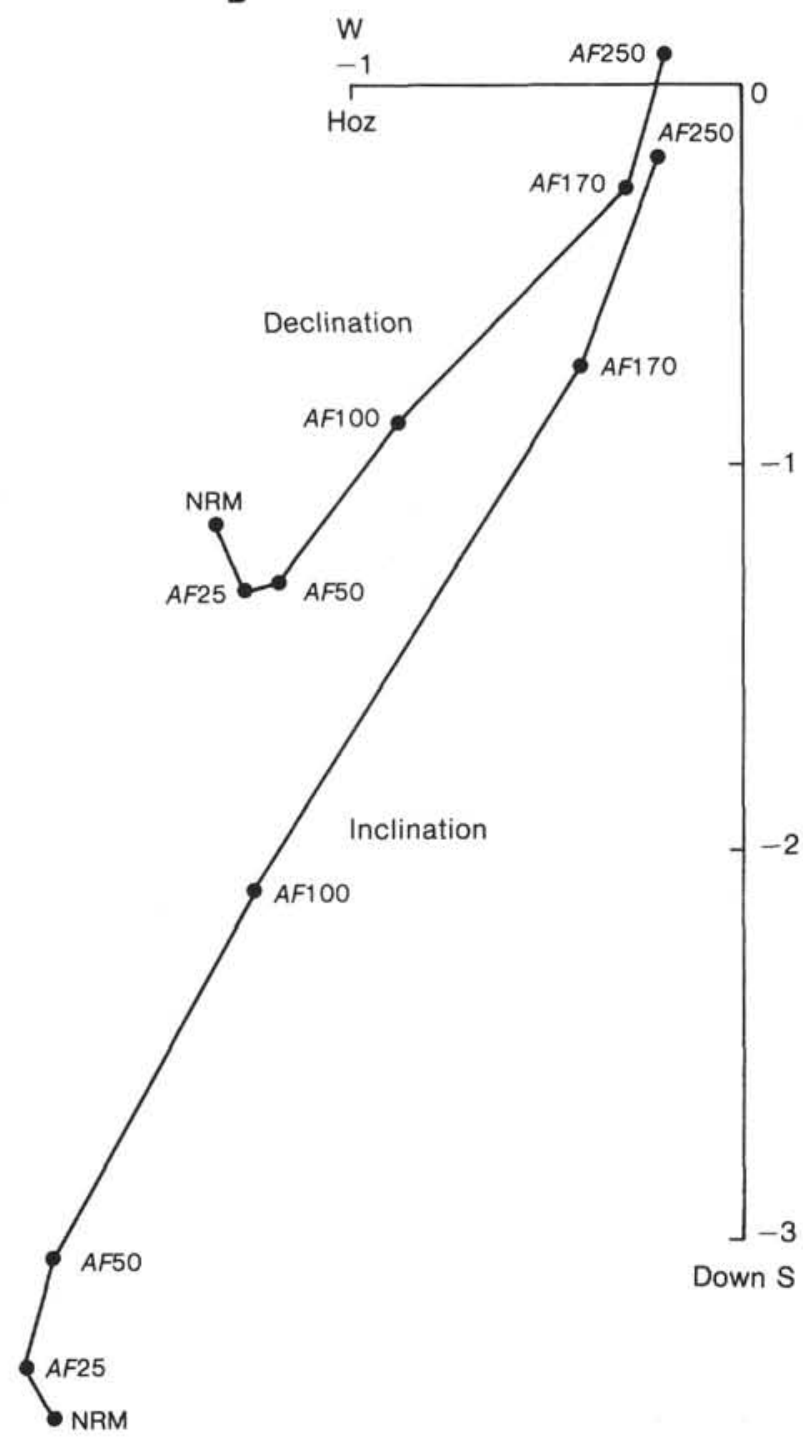

Figure 4. Vector plots of (A) progressive thermal demagnetization and (B) progressive AF demagnetization of a split sample of white limestone from Site 534 (Sample 534A-90-2, $37 \mathrm{~cm}$ ). Thermal treatment above $300^{\circ} \mathrm{C}$ removed a normal-polarity overprint to reveal a reversed-polarity characteristic magnetization which was not apparent with AF treatment. Final polarity interpretation is "REP" = definitely reversed but direction should be given only half-weight in computation of paleolatitudes. Characteristic magnetization is $-40.2^{\circ}$ inclination with a mean intensity of $6.1 \times$ $10^{-5} \mathrm{~A} / \mathrm{m}$.

On the vector plots, inclination (Up, Horizontal [Hoz], Down) is plotted with the total intensity of magnetization at the given demagnetization step. Declination (N,E,S,W) is plotted as the horizontal component of the magnetization vector; for samples from Site 534 the initial (NRM) declination is arbitrary because orientation control is lacking. (1 scale div. $=10^{-4} \mathrm{~A} / \mathrm{m}$ ) 
stone and laminated marl-were essentially identical. NRM intensities were typically between 5 and $15 \times 10^{-5}$ $\mathrm{A} / \mathrm{m}$. Nearly every NRM inclination was within the range of $30^{\circ}$ to $65^{\circ}$. For the oriented samples at Site 603 , the NRM declinations were preferentially clustered northward $\left(0^{\circ} \pm 50^{\circ}\right)$ even for those samples later displaying southward-directed reversed polarity. Progressive AF demagnetization of pilot samples had negligible effects on the directions of magnetization.

Thermal demagnetization resulted in a dramatic removal of this normal overprint, with a reversed direction apparent in some cases upon heating above $120^{\circ} \mathrm{C}$. The magnetic behavior of a suite of pilot samples upon thermal demagnetization is shown in Figure 5. In general, the unblocking temperature was between $120^{\circ}$ and $150^{\circ} \mathrm{C}$, with semistable directions maintained from $180^{\circ}$ to $300^{\circ} \mathrm{C}$. The mean intensity of these stable directions was very weak, generally in the range of 1 to $5 \times 10^{-5}$ $\mathrm{A} / \mathrm{m}$. Many samples had intensities below $4 \times 10^{-6}$ $\mathrm{A} / \mathrm{m}$ upon heating above $200^{\circ} \mathrm{C}$. Further heating above $350^{\circ} \mathrm{C}$ generally resulted in the acquisition of unstable viscous magnetization.

This magnetic behavior is interpreted similarly to that of the underlying white limestones: a secondary overprint carried by goethite and/or pyrrhotite, the primary magnetization carried by magnetite, and the unstable behavior introduced above $300^{\circ} \mathrm{C}$ caused both by the decomposition of geothite and by the transformation of pyrite (finely dispersed throughout these sediments) to other magnetic mineral phases. Other interpretations are possible, and further magnetic property studies are required to identify the magnetic mineralogy at different temperature steps.

The domination of NRM by secondary normal-polarity overprints, which are removed by thermal demagnetization, has been observed in the lithified sediments recovered at other DSDP sites, and it is suspected that such overprints may be the reason for the poor results given by earlier magnetostratigraphic studies of Lower Cretaceous-Upper Jurassic DSDP sediments employing only AF demagnetization. This type of AF-resistent overprint is not often reported in unlithified DSDP sediments, which suggests that it is produced by the formation of new magnetic mineral phases during lithification diagenesis and by long-term moderate heating of the sediments at depths below $1 \mathrm{~km}$ (typical heat flow calculations and measured temperatures during logging of DSDP Site 534 indicate a temperature of $35^{\circ}-40^{\circ} \mathrm{C}$ at a depth of $1 \mathrm{~km}$ and estimates of $50^{\circ}-60^{\circ} \mathrm{C}$ at $1.5 \mathrm{~km}$ (Henderson and Davis, 1983). It is therefore recommended that any deeply buried lithified pelagic sediments recovered at DSDP sites should undergo thermal demagnetization to remove secondary overprints. Pelagic sediments exposed on land generally require thermal demagnetization as well (Lowrie and Heller, 1982).

\section{Clastic Turbidites (Hauterivian-Barremian)}

Hole 534A, especially Cores 56-61; and Hole 603B, especially Cores 44-57.

There are abundant turbidites of siltstone-sandstone and of organic-matter-rich claystone at both sites and of clastic carbonate at Site 534. This turbidite input was not sampled for paleomagnetism, except within those intervals (noted earlier) in which the pelagic carbonate beds were not abundant enough to provide a full sample suite. The magnetic behavior of the different types of turbidites varied greatly. Many of the siltstone-sandstone beds had very strong magnetizations (averaging $1 \times 10^{-3}$ $\mathrm{A} / \mathrm{m}$ ), which were unaffected by thermal demagnetization up to $500^{\circ}$ and were considered to be unreliable indicators of polarity. The magnetic behavior of the claystone turbidites was similar to that of the host pelagic sediments described previously, though with intensities higher by a factor or two to ten.

\section{Black to Grayish Red Claystone (Aptian-Albian)}

\section{Hole 603B, Cores 40-43.}

This lithology had the strongest intensities and the most stable directions of magnetization. Typical NRM intensities were $1 \times 10^{-3} \mathrm{~A} / \mathrm{m}$ for the black claystone and a phenomenal $1 \times 10^{-1} \mathrm{~A} / \mathrm{m}$ for the reddish claystone. Thermal demagnetization removed a steep normal component; stable directions were maintained above $200^{\circ} \mathrm{C}$. Some samples displayed viscous unstable magnetization above $350^{\circ} \mathrm{C}$ when the intensity of magnetization was about $5 \%$ of NRM; other samples had stable directions up to $530^{\circ} \mathrm{C}$. Demagnetization plots of typical samples are displayed in Figure 6, including the single sample which displayed reversed polarity upon heating above $250^{\circ} \mathrm{C}$.

A separate study of the magnetic properties and directions of magnetization of the upper claystone unit of Hole 603B (Cores 38-41) was performed by G. Canninga. His report is attached as Appendix A. All of these samples have normal polarity.

\section{POLARITY INTERPRETATION AND MEAN DIRECTIONS OF SAMPLES}

Polarity was interpretated and the mean direction of characteristic magnetization was computed on each individual sample by an analysis of the magnetic directions during demagnetization and by applying a leastsquares line fit to the region of semistability.

For each sample, a vector plot of the directions of magnetization during progressive thermal demagnetization was examined to assign polarity and to identify the region of linear decay toward the origin in order to compute the characteristic direction of magnetization. Examples of some of these plots with their interpretations are in Figures 4 to 6 . Most samples displayed removal of a normal overprint during the early thermal demagnetization steps, a phenomenon which aided in placing a declination relative to "north" upon the successive magnetic directions.

Polarity interpretation of most samples was therefore very simple. Normal-polarity samples typically had a $10^{\circ}$ to $30^{\circ}$ counterclockwise shift between the declinations of the NRM and of the $150^{\circ}-180^{\circ} \mathrm{C}$ demagnetization step, accompanied by a $20^{\circ}$ to $30^{\circ}$ shallowing of inclination. Reversed-polarity samples typically displayed a rapid $120^{\circ}$ to $180^{\circ}$ shift of declination between NRM and the $150^{\circ}-180^{\circ} \mathrm{C}$ step, accompanied by a change to negative 
inclination. Departures from these ideal behaviors were assigned polarity interpretations of N?, R?, or INT (intermediate or indeterminant) depending upon a subjective evaluation of the magnetic behavior; the final polarity stratigraphy gave very little weight to these samples and their directions were not used in computing paleolatitudes. A conservative approach was adopted in assigning polarity-if the polarity was not immediately obvious from the demagnetization behavior, then the polarity was assigned to an "uncertain" category.

In general, the reversed-polarity samples had slightly lower intensities at a given demagnetization step than adjacent normal-polarity samples, and the reversed-polarity directions had considerably more scatter. The average inclinations of reversed-polarity directions were shallower than the normal-polarity directions. These characteristics suggest that a weak, persistent overprint of normal polarity with steeper inclination (probably present field) was present even at high thermal demagnetization steps. Unfortunately, this persistent overprint generally appears to be removed simultaneously with the primary magnetization: for most samples, the demagnetization vector plots show a linear decay to the origin, rather than to a point offset from the origin, as would be expected from a residual secondary overprint stable at higher temperatures.

The characteristic directions of magnetization and associated variances were computed by applying the threedimensional least-square line fit method of Kirschvink (1980) to the vectors of magnetization within the region of semistability identified for each sample. The mean characteristic direction derived from this least-squares technique is a more accurate and less biased representation of the stable magnetization than selecting a single uniform demagnetization for all samples, or subjectively choosing a "best step" direction for each of the samples. The intensity of characteristic magnetization of each sample is the mean of the intensities of the vectors used in the least-squares computation.

For computing paleolatitudes, these characteristic directions were split into two groups according to their reliability. A characteristic direction was rated "poor" if any of the following criteria applied: (1) the sample polarity interpretation was uncertain, (2) the mean intensity was less than $5 \times 10^{-6} \mathrm{~A} / \mathrm{m},(3)$ the standard deviation of the directions within the region of stability was $10^{\circ}$ or greater, (4) only a single demagnetization step was used, or (5) there had been difficulty in orienting the sample during collection. These less reliable characteristic directions (totaling about one-third of the samples) are denoted in the Appendices to this chapter and on Figures 7 and 8 (in back pocket) by the label "NOP" or "REP" and were given only half-weight in the computation of paleolatitudes. As expected, a greater percentage of the reversed-polarity samples had "poor" directions compared to the normal-polarity samples.

The declinations of characteristic magnetization for the Site 534 samples are entirely random, as would be expected for unoriented vertical drill cores; therefore, the declinations are of no significance. At Hole 603B, however, the declinations of about two-thirds of the mini- cores are oriented relative to the "apparent dip" direction of the sediment laminae; these are plotted in Figure 8 , in the back pocket, and tabulated in Appendix C, and also served as an indication of reversed or intermediate polarity.

The characteristic directions and intensities of magnetization and the polarity interpretations with reliability indices of all samples appear in Appendices B and C.

\section{MAGNETOSTRATIGRAPHY}

\section{Polarity Columns Uncorrected for Turbidite Episodes}

For each site, a stratigraphic plot was prepared of depth, core number, and recovery, lithologic units and subunits, the various biostratigraphic zonations and horizons, the inclination and intensity of characteristic magnetization, and the polarity interpretation of each sample (Figs. 7 and 8 , in back pocket).

Early results for the Kimmeridgian through Berriasian portion of Site 534 had been previously published in Ogg (1983). In the present study, the samples underwent further demagnetization, supplemental new samples were analyzed, and characteristic magnetizations were recomputed using the least-squares method. The Valanginian through Aptian portion of Site 534 had not previously been studied.

For Site 603 , the declinations of characteristic magnetization are included on the stratigraphic plot (Fig. 8, back pocket). It is obvious from the high degree of scatter of the declinations that many samples were unoriented or misoriented during shipboard collection. However, for the majority of samples, the declinations of characteristic magnetization are oriented relative to the direction of "apparent dip" of laminae, thereby aiding in the polarity-zone identification. If deep-sea laminated sediments were deliberately rotary-cored at a moderate angle to vertical, then the declinations relative to the direction of this deviation could enable polarity records and pole positions to be obtained with a reliability comparable to land-based paleomagnetic studies.

The inclinations of characteristic magnetization are plotted on a $-70^{\circ}$ to $+70^{\circ}$ scale; it was unnecessary to use a full $\pm 90^{\circ}$ scale because there were few anomalously steep inclinations. The inclinations at Site 603 appear to be steeper than those of Site 534. This steepening is mainly attributed to the $16.4^{\circ}$ deviation northward of Hole 603B from vertical (as will be discussed later).

The polarity interpretations with the index of reliability (NOR-NOP-N?-INT-R?-REP-REV) were converted to a generalized standard-format polarity column $($ black $=$ normal polarity, white $=$ reversed) by identifying intervals of similar polarity. Samples having N?, R?, or INT polarity interpretations were generally ignored. Of course, there is the possibility that a concentration of samples with uncertain polarity actually indicates a reversed-polarity zone in which secondary overprints were not adequately removed (e.g., the lower part of Core 603B-77); however, the quality of the available data does not justify the use of these samples for 
A

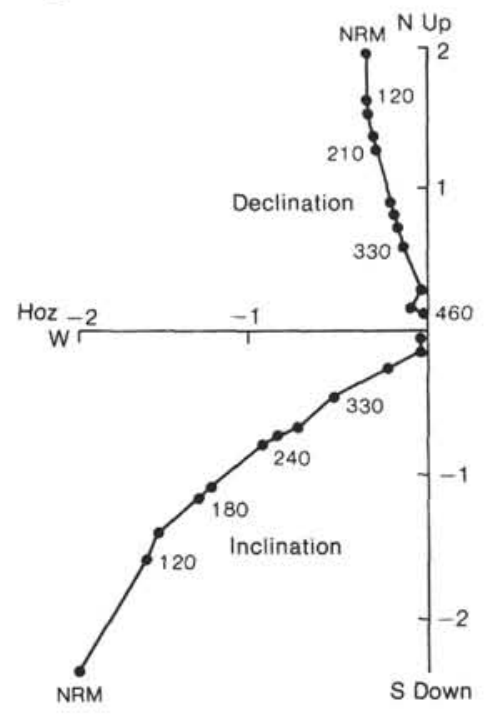

B

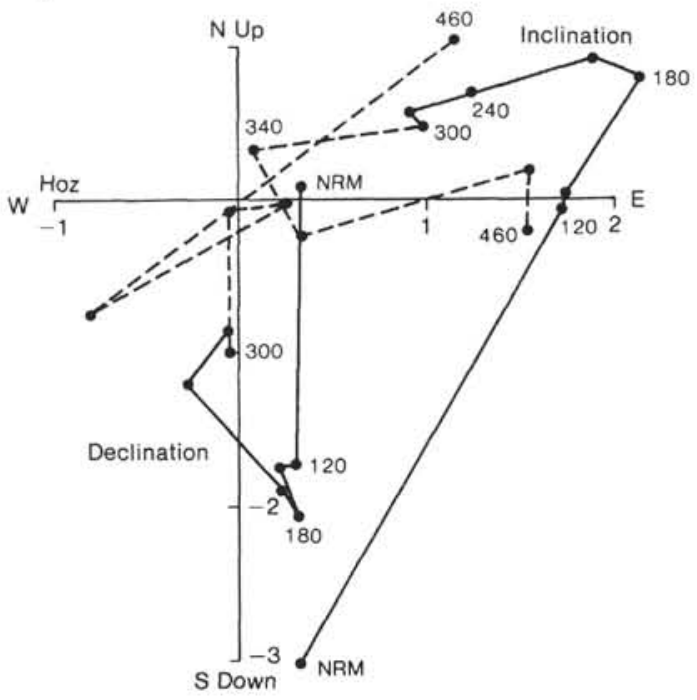

Figure 5. Selected thermal demagnetization pilot samples from Site 603 illustrating typical magnetic behaviors. All samples were oriented with respect to the azimuth of apparent dip of laminae (which was near to the azimuth of paleonorth). Directions are not corrected for deviation of the hole from vertical. Construction of vector plots is explained in Figure 4. Demagnetization steps are in ${ }^{\circ} \mathrm{C}$, and are usually in $30^{\circ}$ increments from $120^{\circ}$ to $330^{\circ}$, then $40-50^{\circ}$ increments to higher temperatures. Hoz $=$ horizontal. A. Sample $603 \mathrm{~B}-58-4,48 \mathrm{~cm}$, white bioturbated limestone, Barremian. Stable normal polarity after removal of a steeper normal overprint with declination slightly more eastward. Characteristic magnetization $=$ $347.2^{\circ}$ declination, $41.0^{\circ}$ inclination, $1.3 \times 10^{-4} \mathrm{~A} / \mathrm{m}$ mean intensity. (1 scale div. $=10^{-4} \mathrm{~A} / \mathrm{m}$.) B. Sample $603 \mathrm{~B}-65-4$, $17 \mathrm{~cm}$, light gray laminated marly limestone, Hauterivian. An overprint of normal polarity was removed by heating at low temperatures to yield a reversed polarity. Upon heating above $340^{\circ} \mathrm{C}$, unstable viscous magnetization was dominant (dashed lines). Characteristic magnetization $=178.2^{\circ}$ declination, $-26.7^{\circ}$ inclination, $1.2 \times 10^{-5} \mathrm{~A} / \mathrm{m}$ mean intensity. (1 scale div. $=10^{-5} \mathrm{~A} / \mathrm{m}$.) C. Sample 603B-66-1,33 cm, mixed bioturbated and laminated marly limestone, Hauterivian. Normal polarity after removal of a steeper normal-polarity overprint with a slightly more eastward declination. Characteristic magnetization $=326.6^{\circ}$ declination, $52.0^{\circ}$ inclination, $4.7 \times 10^{-5} \mathrm{~A} / \mathrm{m}$ mean intensity. $\left(1\right.$ scale div. $=10^{-5} \mathrm{~A} / \mathrm{m}$.) D. Sample 603B-82-1, $70 \mathrm{~cm}$, white limestone, Berriasian. Normal polarity after removal of a steeper normal-polarity overprint. Characteristic direction $=349.4^{\circ}$ declination, $62.2^{\circ}$ inclination, $5.1 \times 10^{-5} \mathrm{~A} / \mathrm{m}$ mean intensity. (1 scale div. $=10^{-5} \mathrm{~A} / \mathrm{m}$.) E. Sample 603B-82-5, $22 \mathrm{~cm}$, mixed laminated and bioturbated limestone, Berriasian. Reversed polarity after removal of a normal-polarity overprint, but the stability of the direction is poor. Viscous magnetization is dominant at $380^{\circ} \mathrm{C}$ and above. Characteristic magnetization $=172.3^{\circ}$ declination, $-26.0^{\circ}$ inclination, $2.4 \times 10^{-5} \mathrm{~A} / \mathrm{m}$ mean intensity. (1 scale div. $=10^{-5} \mathrm{~A} / \mathrm{m}$.)

magnetostratigraphy. In these magnetostratigraphic columns, major gaps in sampling or intervals of poor data are represented by a hachured pattern; single samples having a polarity interpretation opposite the adjacent samples are denoted by a short bar. The uncertainty in drawing the boundaries of polarity zones is inherent in the 50-to-100-cm spacing of samples, plus an unknown portion of the amount of nonrecovery of that core. DSDP convention was followed in representing the percentage of nonrecovery of a core by a void space at the base of that core; obviously, much of this nonrecovery is actually the cause of recognizable breaks within the recovered core section.

The mean intensities of characteristic magnetization for both sites show general trends of (1) an upward decrease in average intensity for the Berriasian white limestone into the Valaginian-Hauterivian cyclic laminated/ bioturbated carbonates, (2) an interval near the Hauterivian/Barremian boundary of high average intensity, in part a reflection of the inclusion of turbidite samples with strong intensities, and (3) an extended interval of low intensity within the Barremian. There is a sudden upward change to the Aptian-Albian strongly magnetized black and reddish claystone of Site 603 .

\section{Polarity Columns with Turbidites Removed}

The relative thicknesses of polarity zones at Sites 534 and 603 are distorted by pulses of turbidite input, which make it difficult directly to compare the magnetostratigraphies between sites. Therefore, synthetic stratigraphic columns of only the pelagic sediments were constructed for each site. The pelagic sediment facies from the Valanginian through Barremian is a monotonous, cyclic alternation of laminated marl and bioturbated limestone, which is considered to be a continous record with no major changes in sedimentation rate. This assumption is probably an oversimplification. No hiatuses are indicated by gaps in the biostratigraphic events, by sudden facies changes, or by reflectors in seismic profiles, though it is possible that there was some erosion of the pelagic sediment when the siltstone-sandstone turbidite beds were emplaced. In particular, Sarti and von Rad (this volume) have suggested that there may be Barremian strata missing at the base of the very thick, coarse-grained turbidite beds at Site 603 .

A detailed lithologic coding of every bed at each site for the Valanginian, Hauterivian, and Barremian in both sites was made from visual observation of the cores by 
C

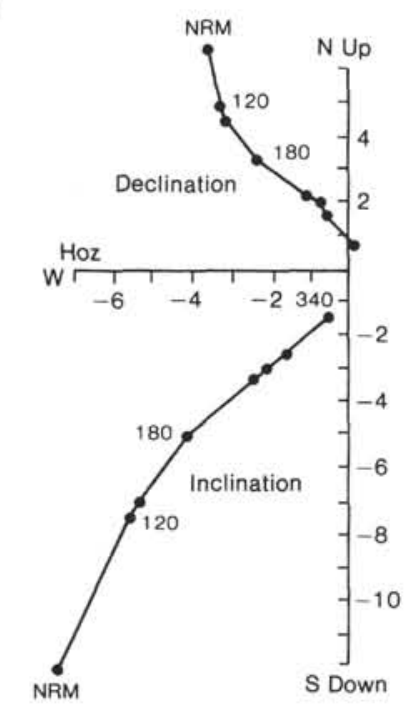

D

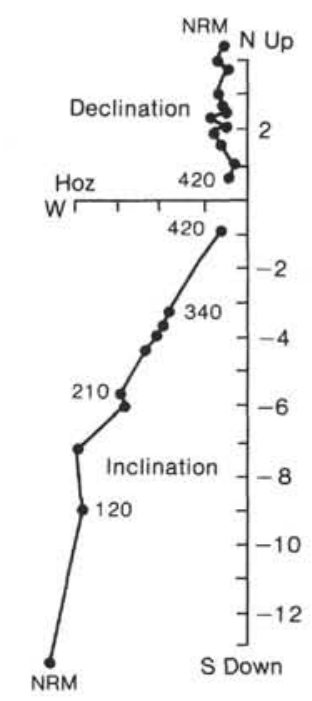

E

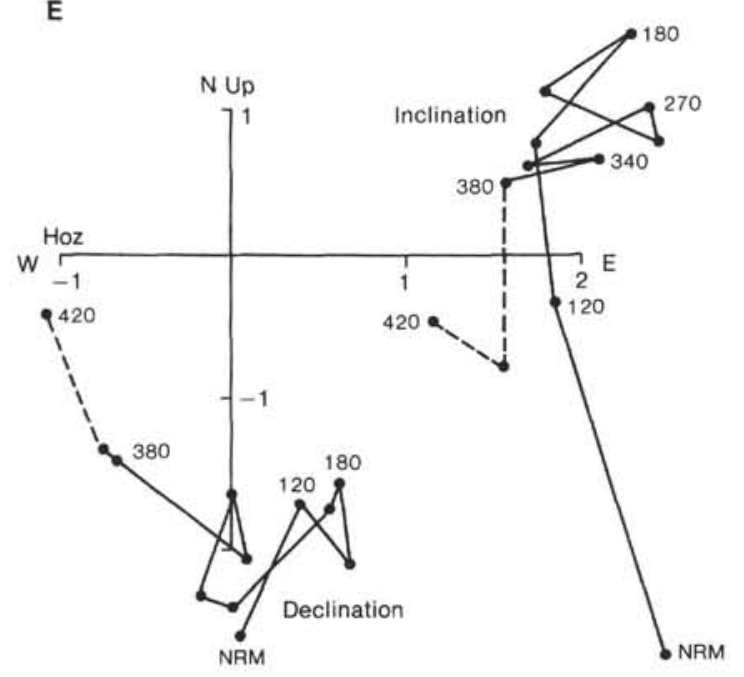

Figure 5 (continued).

the shipboard sedimentologists, or from examination of the cores at the DSDP East Coast Repository at Lamont-Doherty. These descriptions consist of about 3200 entries for Hole 603B and about 4400 entries for Hole $534 \mathrm{~A}$, and are effectively a centimeter-by-centimeter coding of the sedimentary column. All major and minor breaks in recovery and "void" spaces in the cores were included in these computer data files.

Pelagic sediment columns were constructed by the following procedure: (1) An estimate of the ratio of turbidite to pelagic sediments missing in the "voids" of nonrecovery for each core was derived by assuming that the proportion was the same as for a 20 -m window centered on that void. (2) The thicknesses of all turbidites and the estimated percentages of turbidites represented by the voids were subtracted from the sediment column. (3) The remaining pelagic stratigraphic columns were constructed using an arbitrary initial meter level $(1000 \mathrm{~m}$ for the top of Core 45 of Hole 534A; $1200 \mathrm{~m}$ for the top of Core 49 of Hole 603B). The pelagic portions of Cores
40-48 of Hole 603B lacked a computerized database of lithologies, so the percentage of the pelagic component in each core was computed from the detailed stratigraphic columns by Sarti and von Rad (this volume) and from the shipboard section-by-section visual descriptions. The statistics for the pelagic column of each site are given in Table 5.

The pelagic sediment column for each site, showing the computed thickness and recovery of each core and the placement of lithologic formation boundaries and biostratigraphic events, is summarized in Figure 9, back pocket. The polarity columns were constructed by scaling the core-by-core polarity patterns of back pocket Figures 7 and 8 to the new core thicknesses. The effects of removing the distortion introduced by turbidites are most dramatic for Cores 52-62 of Hole 534A and Cores 44-60 and 70-73 of Hole 603B; in these intervals, turbidites comprise over half of the recovered sediments. With the removal of these major distortions, the polarity columns can be compared more easily. 

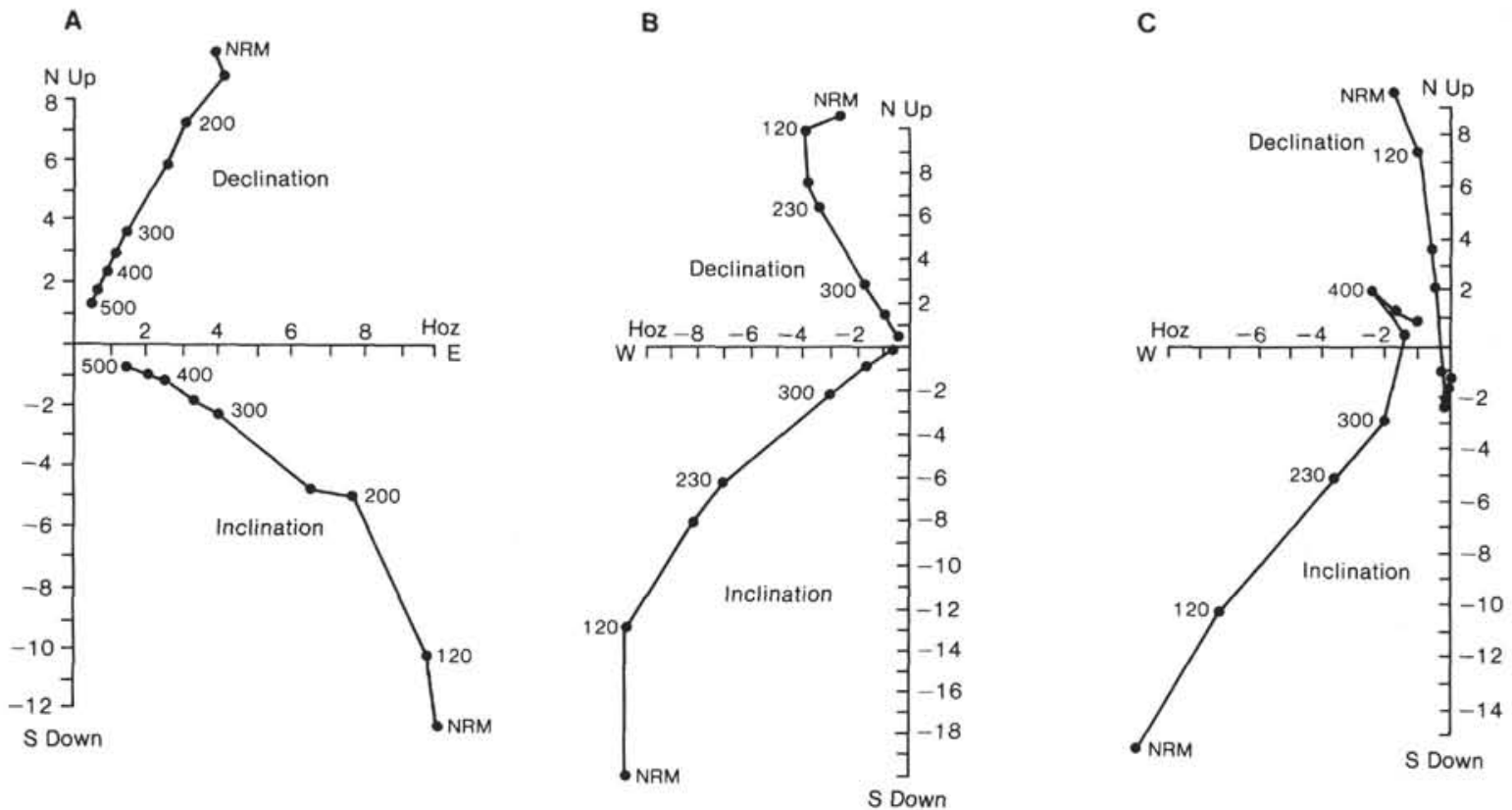

Figure 6. Thermal demagnetization of brick red Aptian-Albian claystones, Site 603. All samples were oriented with respect to the azimuth of apparent dip of laminae (which was near to the azimuth of paleonorth). Directions are not corrected for deviation of the hole from vertical. Construction of vector plots is explained in Figure 4 . Hoz $=$ horizontal. $\left(1 \mathrm{scale}\right.$ div. $=10^{-2} \mathrm{~A} / \mathrm{m}$.) A. Sample $603 \mathrm{~B}-41-1,80 \mathrm{~cm}$, normal polarity. Characteristic magnetization $=21.6^{\circ}$ declination, $28.9^{\circ}$ inclination, $2.8 \times 10^{-2}$ $\mathrm{A} / \mathrm{m}$ mean intensity. B. Sample 603B-41-2, $70 \mathrm{~cm}$, normal polarity. Characteristic magnetization $=332.1^{\circ}$ declination, $42.3^{\circ}$ inclination, $2.7 \times 10^{-2} \mathrm{~A} / \mathrm{m}$ mean intensity. C. Sample $603 \mathrm{~B}-41-3,16 \mathrm{~cm}$, reversed polarity upon heating above $250^{\circ} \mathrm{C}$. Characteristic magnetization $=181.8^{\circ}$ declination, $-41.0^{\circ}$ inclination, $3.2 \times 10^{-2} \mathrm{~A} / \mathrm{m}$ mean intensity.

\section{MAGNETOSTRATIGRAPHIC CORRELATION BETWEEN SITES}

\section{Correlation Criteria and Sources of Uncertainty}

The correlation of the polarity intervals of Sites 534 and 603 is based upon the biostratigraphic event horizons, upon pelagic sediment characteristics, and upon the general features of each polarity column.

In back-pocket Figure 9 are shown the main independent controls on correlating the stratigraphic columns of the two sites: 6 first appearance datums of key species (4 dinoflagellate index species, 2 nannofossil species), 7 last appearance datums ( 2 dinoflagellate, 5 nannofossil), and 10 changes in the general characteristics (subunits) of the pelagic sediments. The reliability and precision of each of these types of correlations vary greatly.

In general, the first occurrences of dinoflagellate index species are considered to be more reliable than first occurrences of nannofossils because the dinoflagellate events were determined by the same paleontologists for both sites (D. Habib and W. Drugg) and do not seem to suffer so much from irregular preservation of rare species or taxonomic difficulties. For the same reasons, the placement of last appearance datums of dinoflagellate index species may be more precise than the determinations of last occurrences of nannofossil species. However, the abundant redeposition by turbidite events, which were also sampled for paleontology, may have significantly displaced upward the last occurrences of some species.

Subdivision of the pelagic sediment column into lithologic subunits was based on the relative proportions of lithologic types and the clarity of development of cycles (Table 4). The boundaries between these subunits are generally gradual transitions, as would be expected from continuous pelagic sedimentation, so the exact placement of most of the boundaries is somewhat arbitrary within an interval of several meters. In addition, there is no $a$ priori reason why changes in the character of the pelagic sediments should be synchronous between sites which are separated by nearly $1000 \mathrm{~km}$.

An examination of back-pocket Figure 9 shows that the facies subunits and first appearance datums imply a fairly constant relative pelagic sedimentation rate between sites (i.e., the scales are linear with respect to each other). The sedimentation rate of Site 534 is about $30 \%$ greater than that of Site 603 , perhaps as a result of a higher carbonate productivity at the more southern latitude of Site 534.

The magnetostratigraphy of any section has inherent uncertainties caused by several factors, including the following:

1. The sediment column may contain brief hiatuses or erosional events beyond the resolution of biostratigraphy and unrecognized by sedimentologists, but able to remove a short magnetic polarity zone.

2. Remanent magnetization carried by detrital grains, such as magnetite, is set during early dewatering of the sediment, not at the sediment-water interface; therefore, the timing of magnetization can lag the actual age of the sediment deposition by tens of thousands of years.

3. A later polarity episode may cause permanent remagnetization of some of the earlier sediment through reorientation of a majority of the magnetite grains. 
Table 5. Sites 534 and 603: stratigraphic scale for pelagic sediments.

\begin{tabular}{|c|c|c|}
\hline $\begin{array}{c}\text { Core } \\
\text { no. }\end{array}$ & $\begin{array}{c}\text { Pelagic } \\
\text { component } \\
\text { (computed \%) }\end{array}$ & $\begin{array}{c}\text { Top of core on } \\
\text { synthetic pelagic } \\
\text { stratigraphic column } \\
(\mathrm{m})\end{array}$ \\
\hline \multicolumn{3}{|l|}{ Hole 534A } \\
\hline 45 & 92 & 1000.00 \\
\hline 46 & 90 & 1008.27 \\
\hline 47 & 94 & 1016.33 \\
\hline 48 & 95 & 1022.05 \\
\hline 49 & 96 & 1030.32 \\
\hline 50 & 82 & 1039.57 \\
\hline 51 & 55 & 1045.91 \\
\hline 52 & 42 & 1050.88 \\
\hline 53 & 77 & 1054.62 \\
\hline 54 & 33 & 1061.56 \\
\hline 55 & 36 & 1064.57 \\
\hline 56 & 28 & 1067.84 \\
\hline 57 & 18 & 1070.36 \\
\hline 58 & 45 & 1072.00 \\
\hline 59 & 47 & 1076.06 \\
\hline 60 & 50 & 1080.32 \\
\hline 61 & 46 & 1084.84 \\
\hline 62 & 51 & 1088.95 \\
\hline 63 & 74 & 1093.52 \\
\hline 64 & 84 & 1100.18 \\
\hline 65 & 87 & 1107.72 \\
\hline 66 & 96 & 1115.57 \\
\hline 67 & 93 & 1124.19 \\
\hline 68 & 93 & 1128.55 \\
\hline 69 & 90 & 1136.74 \\
\hline 70 & 92 & 1144.87 \\
\hline 71 & 85 & 1153.13 \\
\hline 72 & 93 & 1160.79 \\
\hline 73 & 97 & 1169.18 \\
\hline 74 & 95 & 1177.95 \\
\hline 75 & 96 & 1186.46 \\
\hline 76 & 91 & 1195.08 \\
\hline 77 & 90 & 1203.32 \\
\hline 78 & 92 & 1208.20 \\
\hline 79 & 99 & 1215.61 \\
\hline 80 & 100 & 1224.52 \\
\hline 81 & 100 & 1233.52 \\
\hline 82 & 100 & 1242.52 \\
\hline 83 & 100 & 1259.13 \\
\hline 84 & 98 & 1276.87 base of section \\
\hline \multicolumn{3}{|l|}{ Hole 603B } \\
\hline 40 & 100 & 1164.42 \\
\hline 41 & 100 & 1173.42 \\
\hline 42 & 100 & 1179.92 \\
\hline 43 & 85 & 1187.52 \\
\hline 44 & 20 & 1195.68 \\
\hline 45 & 5 & 1197.60 \\
\hline 46 & 5 & 1198.08 \\
\hline 47 & 5 & 1198.56 \\
\hline 48 & 10 & 1199.04 \\
\hline 49 & 22 & 1200.00 \\
\hline 50 & 29 & 1202.12 \\
\hline 51 & 36 & 1204.94 \\
\hline 52 & 36 & 1208.36 \\
\hline 53 & 43 & 1211.80 \\
\hline 54 & 21 & 1215.90 \\
\hline 55 & 14 & 1217.89 \\
\hline 56 & 11 & 1219.19 \\
\hline 57 & 12 & 1220.21 \\
\hline 58 & 27 & 1221.35 \\
\hline 59 & 27 & 1223.95 \\
\hline 60 & 33 & 1226.93 \\
\hline 61 & 56 & 1230.13 \\
\hline 62 & 57 & 1235.48 \\
\hline 63 & 74 & 1240.63 \\
\hline 64 & 61 & 1247.69 \\
\hline 65 & 51 & 1253.14 \\
\hline 66 & 63 & 1257.77 \\
\hline 67 & 42 & 1263.43 \\
\hline 68 & 61 & 1267.18 \\
\hline 69 & 71 & 1272.71 \\
\hline 70 & 40 & 1279.08 \\
\hline 71 & 32 & 1282.71 \\
\hline 72 & 41 & 1285.58 \\
\hline 73 & 35 & 1287.64 \\
\hline 74 & 77 & 1291.04 \\
\hline 75 & 68 & 1298.47 \\
\hline 76 & 98 & 1305.00 \\
\hline 77 & 100 & 1314.38 \\
\hline 78 & 100 & 1324.15 \\
\hline 79 & 100 & 1333.48 \\
\hline 80 & 100 & 1342.75 \\
\hline 81 & 100 & 1351.28 \\
\hline 82 & 100 & $\begin{array}{l}1360.28 \\
1367.31 \text { base of section }\end{array}$ \\
\hline
\end{tabular}

4. Postdepositional changes in the redox potential (Eh) of interstitial waters and diagenetic recrystallization can create secondary magnetic minerals having magnetic directions oriented toward the later ambient field or can result in the dissolution of the primary magnetic minerals.

5. Gaps in sample collection or core recovery may prevent identification of a polarity zone.

6. The assignment of polarity to a sample is a partially subjective process, highly influenced by the success of the demagnetization techniques in removing secondary overprints and by the judgment of the paleomagnetist as to which steps are to be considered the characteristic magnetization.

The cautions just noted must be considered when deriving and correlating magnetostratigraphic columns and assigning polarity zones.

The magnetostratigraphies were correlated using the following criteria:

1. Single-sample polarity events or very narrow polarity zones were generally ignored.

2. Polarity-zone correlations must parallel first appearance datums of key index species of dinoflagellates and nannofossils, although the placement of these datums could easily have an uncertainty of several meters in either direction. In the case of disagreement between adjacent dinoflagellate and nannofossil datums, the dinoflagellate datum was considered to be more reliable.

3. Polarity-zone correlations should parallel the boundaries between recognized lithologic subunits of the pelagic sediments.

4. A fairly continuous pelagic sedimentation rate should be maintained for each site; therefore, all major polarity features should be present in both sites and the correlations must not imply a highly variable sedimentation rate of one site with respect to the other (i.e., the scales should be linear with respect to each other). This rule was not observed for the Barremian/Aptian boundary because major hiatuses are present at one site or the other.

5. The relative thicknesses of polarity intervals should be similar between sites but not necessarily identical, because the timing of setting of magnetization and the success in removing secondary overprints may vary between sites.

\section{Magnetostratigraphic Correlations}

The magnetostratigraphic correlations shown in Figure 9 (back pocket) were made according to the criteria just discussed. The major correlated reversed-polarity zones are numbered from 1 to 7 . Reversed-polarity zone 1 parallels the first appearance of the dinoflagellate Druggidium apicopaucicum and the base of pelagic lithologic subunit B1. This correlation is somewhat uncertain because of a possible hiatus in sedimentation at the Valanginian/Berriasian boundary at Site 534. A possible correlation of the reversed-polarity samples at the base of Hole 603B with the top of polarity zone M16 at Site 534 is tentative. Reversed-polarity zone 2 and zones 4 through 7 parallel adjacent biostratigraphic events (primarily dinoflagellate) and lithologic subunits. The short 
polarity intervals between zones 1 and 2 (i.e., encompassing most of the Valanginian stage) could not be correlated with any certainty; possibly this mismatch is caused by the difficulty of interpreting the weak magnetizations at both sites (note the abundance of uncertain polarity interpretations in Fig. 7 and 8, back pocket). Reversedpolarity zone 3 was made subparallel to the other zones; the difference in the apparent thickness of this reversedpolarity zone ( $7 \mathrm{~m}$ versus $3 \mathrm{~m}$ ) may be the result of brief sedimentation interruptions, of a persistent normal overprint on some adjacent "normal" samples at Site 534, or of improper computation of the amount of pelagic sediment. Zone 4 implies that the uncertain short normal interval recorded in the lower portion of Core 603B63 was not sampled at Site 534. Zone 7 is complicated by hiatuses within the lower Aptian and upper Barremian at Site 603 , which are indicated by the convergence of biostratigraphic datums and of pelagic lithologic subunits, and which apparently condensed most of the reversed polarity interval recorded at Site 534 .

From these magnetostratigraphic correlations, several comparisons can be made of the sedimentation histories of the two sites, in particular the relative timing of major turbidite episodes (discussed in Sarti and von Rad, this volume). For example, an episode of abundant turbidites occurs at each site near reversed-polarity zone 6 (Cores 534A-54 to -57 and Cores 603B-54 to 57; the identical core numbers are a coincidence). On the other hand, the major turbidite episode at Site 603 (Cores 603B-44 to -50 ) is absent at Site 534 , as is the lesser episode near reversed-polarity zone 2 .

\section{CORRELATION TO M-SEQUENCE AND ASSIGNMENT OF POLARITY CHRONS}

The final step is to correlate these magnetostratigraphies to the M-sequence block model of the Hawaiian lineations in order to assign a standard polarity-chron nomenclature to the polarity intervals and to establish better age control on Early Cretaceous magnetic anomalies.

The polarity columns of Sites 534 and 603 are redrawn in Figure 10, placing reversed-polarity zones 3 and 4 on a horizontal level. At first glance, there is no obvious match to the M-sequence block model. The proposed correlations are based on the following criteria and constraints set by known ages of polarity chrons (as previously summarized):

1. Polarity Chron M0 has an age of basal Aptian.

2. Polarity Chron M3 has an age of early Barremian (within nannofossil Zone NC5).

3. The upper Barremian-lower Aptian sediments encompassing reversed-polarity zone 7 of these DSDP sites are condensed (especially in Hole 603B), thereby complicating the identification of M0 through M3.

4. M16 and M17 (and other polarity zones down to M23) of Site 534 have been previously correlated (Ogg, 1983).

5. Between reversed-polarity zone 2 and polarity zone M16 (i.e., the Valanginian stage), no definite assignments are possible owing to the poor reliability of the polarity interpretation.
6. Major features of the magnetostratigraphies from reversed-polarity zones 2 through 6 should have a corresponding polarity chron in the M-sequence block model, but short or closely spaced polarity zones may not be resolvable as distinct magnetic anomalies, and vice versa.

7. The assignments should not imply any sudden changes in sedimentation rate or in spreading rate (i.e., the scales are linear with respect to each other).

Based on these criteria, the following polarity chron assignments are suggested for the major reversed-polarity zones:

Reversed-polarity zone 1 of latest Berriasian age was very tentatively correlated to Chron M15, which has a similar age (Galbrun, 1984). Alternatively, this zone at Site 534 may correspond to a reversed-polarity zone "M15A" located just above M16 in the Berrias section (Galbrun, 1984), but not present in the M-sequence block model. Further studies of upper Berriasian sediments may clarify the actual polarity pattern.

Reversed-polarity zone $2=$ Chron $M 10 N$. This is the last appearance datum (LAD) of the dinoflagellate Scrinodinium dictyotum. In the dinoflagellate biostratigraphy, the Valanginian/Hauterivian stage boundary is placed immediately above the LAD of $S$. dictyotum, but could be higher (D. Habib, pers. comm., 1985). This LAD may have been displaced slightly upward at Site 603 by the abundant turbidite redeposition.

Reversed-polarity zone $3=M 10$. Between zones 2 and 3 are short reversed-polarity zones which may correspond to the brief polarity chrons between $\mathrm{M} 10 \mathrm{~N}$ and M10.

Reversed-polarity zone $4=M 8+M 9$. Resolution of two separate polarity zones is possible at Site 603 , but not at Site 534. The first appearance datum (FAD) of the dinoflagellate Druggidium rhabdoreticulatum is within M8.

Reversed-polarity zone $5=M 7$. This is the FAD of the dinoflagellate Odontochitina operculata (or immediately below the base of the Barremian in dinoflagellate zonation); the LAD of the nannofossil Cruciellipsis cuvillieri is located at the top of M7, and this datum has a possible age of latest Hauterivian (Thierstein, 1973).

Reversed-polarity zone $6=M 5+M 6$. Both polarity chrons may have been resolved at Site 603; however, the pattern is probable distorted at both sites by erosion associated with major turbidite current events. This polarity zone is immediately below the LAD of the nannofossil Speetonia colligata at these sites; an event which Roth (1983) assigns to the Hauterivian/Barremian stage boundary. However, Thierstein (1973) assigns this LAD an age of mid-Hauterivian, hence below the LAD of C. cuvillieri, which is opposite the sequence at these sites. This conflict demonstrates the problems in using these nannofossil LAD's.

Reversed-polarity zone $7=M I+M 3$. The polarity interpretation at the DSDP sites yielded a predominantly, but not constantly, reversed-polarity interval; this is consistent with the short normal-polarity intervals within M3 reported by Channell et al. (1979). The LAD of the dinoflagellate Phoberocysta neocomica is near the top of this interval, but the upper Barremian is very con- 


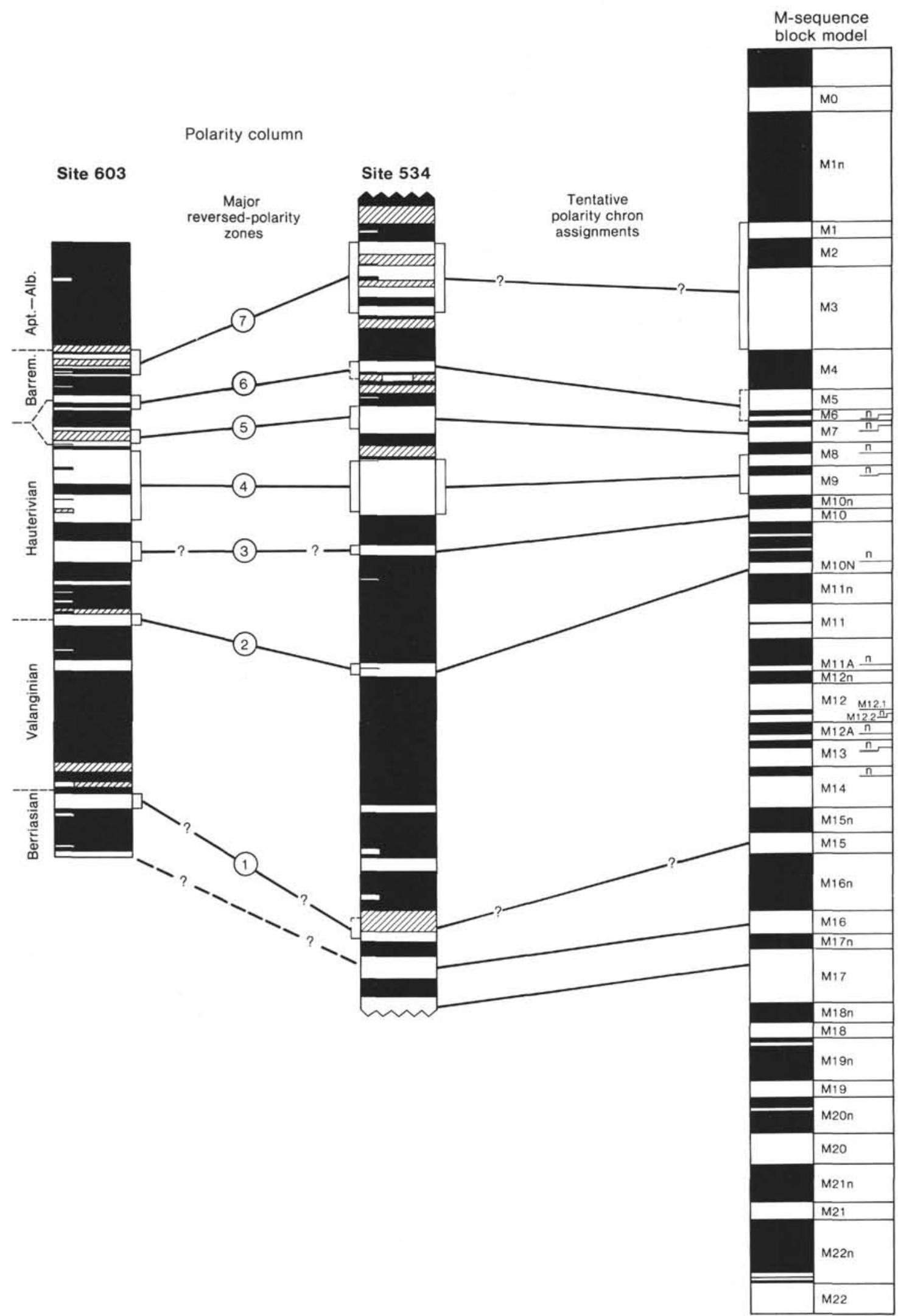

Figure 10. Suggested assignment of polarity chrons (M-sequence) to the reversed-polarity zones correlated in back-pocket Figure 9. Polarity columns have been aligned horizontally at the level or reversed-polarity zones 3 and 4 . Nomenclature of the M-sequence chrons is from Harland et al. (1982). Criteria for the correlations are given in the text. 
densed at Site 603 and possibly has some condensation at Site 534.

M0 (= basal Aptian) was not identified at Site 603, possibly because of an hiatus; paleomagnetic sampling at Site 534 did not extend into the Aptian (nannofossil zonation).

These polarity chron assignments are very tentative and are a "forced" match in some intervals. The main problems are the distortions within the magnetostratigraphic columns and the identification of polarity as discussed previously, although the accuracy of the M-sequence block model from $\mathrm{M} 3$ to $\mathrm{M} 10 \mathrm{~N}$ has yet to be demonstrated. The inability to assign polarity chrons between M10N and M16 is due to a combination of three factors: (1) the difficulty of deciphering the polarity of the weakly magnetized, pyrite-rich sediments of the Valanginian at both sites (there may be more reversed polarity than indicated), (2) a possible major hiatus above polarity zone M16 at Site 534, which may have removed one or more polarity zones, and (3) the possibility that the Hawaiian lineations include unobserved ridge jumps which cause duplication of some magnetic anomalies, hence of polarity chrons in the M-sequence model. This latter possibility will eventually be tested when complete, well-dated, Valanginian-Hauterivian sediment sections yield reliable, reproduceable magnetostratigraphies. These tentative polarity-chron assignments assume that there are no additional major, unidentified hiatuses within the upper Valanginian-Hauterivian-lower Barremian sediments which removed one or more polarity zones at both sites. In general, the polarity-chron assignments satisfy the semiarbitrary assumption that there are linear correspondences between the pelagic sediment columns of the sites and the M-sequence (i.e., sedimentation rate and spreading rates are constant relative to each other).

Based on these assignments, the Hauterivian stage (as defined by dinoflagellate zonation) begins at Chron M10N and ends immediately above Chron M7. Alternatively, the nannofossil-defined Hauterivian at these sites could place its top near Chron M5. Both of these faunal definitions of the top of the Hauterivian are based on last occurrences of key index species, which are rather unreliable owing to possible reworking.

\section{PALEOLATITUDES}

\section{Statistical Method and "Structural" Correction}

True mean inclinations and associated precision parameters were computed following the statistical method developed by Kono $(1980 \mathrm{a}, \mathrm{b})$ for analyzing inclination data from unoriented vertical drill cores. Kono's method was easier to computerize than the procedure developed by McFadden and Reid (1982); either method yields nearly identical results for low-latitude sites. Kono's statistical method is based upon a Fisherian circular distribution of the directions of magnetization (declination and inclination); therefore it is applicable to directions form sediment samples which have an inherent time averaging of secular variation. The method of Cox and Gordon (1984) is based upon a Fisherian distribution of virtual geomagnetic poles; therefore it is more applica- ble to instantaneous directions with high precision (e.g., basalt flows).

The mean inclinations and associated statistical parameters were computed for normal and for reversed polarity of each geologic stage at each site (Table 6). The Valanginian/Hauterivian boundary was set to the middle of M10N and the Tithonian/Berriasian boundary is the base of M18. The computational procedure gave halfweight to inclination data of poor quality (designated NOP or REP in Fig. 7 and 8 and in Appendices B and C), omitted all samples of uncertain polarity, and ignored anomalous inclinations over two standard deviations from the mean. These weighting and selection criteria resulted in larger circular confidence limits than if the total number of samples had been used without weighting. The radii of the $95 \%$ confidence circles $\left(\propto{ }_{95}\right.$ 's) of the true mean inclinations are generally less than $4^{\circ}$, which implies that the standard deviations $\left(\propto_{63}\right)$ of the paleolatitudes are less than $2^{\circ}$.

For Hole 603B, it was necessary to compensate for the $16.4^{\circ}\left( \pm 1.1^{\circ}\right)$ deviation of the hole from vertical before its true mean inclinations could be computed. This correction, which is equivalent to a structural or bedding correction applied to paleomagnetic field data, requires that the azimuth of this deviation, be determined with respect to the direction of magnetization. Samples from Cores $603 \mathrm{~B}-40$ to -43 had been oriented with respect to the apparent dip direction of the laminated sediments, had relatively stable characteristic inclinations, and were known to have a primary normal polarity from their Albian-Aptian age (though one sample did display definite reversed polarity). The mean declination of the characteristic magnetizations of this sample set was $1.8^{\circ}$, but with a high scatter (standard deviation $=7.1^{\circ} ; \mathrm{N}=$ 26). Therefore, the azimuth for the $16.4^{\circ}$ deviation of Hole 603B from vertical is oriented $2^{\circ} \pm 7^{\circ}$ counterclockwise with respect to the mean declination of characteristic magnetization. Based on any of the Mesozoic polar wander paths reported for North America (e.g., Steiner, 1982) this $-2^{\circ}$ azimuth with respect to Cretaceous north translates to about $\mathrm{a}-30^{\circ}$ azimuth with respect to present north. The $-2^{\circ}$ azimuth implies that the required "structural" correction is essentially a subtraction of $16.4^{\circ}$ from the sample inclinations (or a shallowing of the reversed-polarity inclinations by $16.4^{\circ}$ ). Samples with declination farther from the mean, hence at greater angles to the structural correction, would have a lesser shallowing of inclination; to partially compensate for this effect, a uniform correction of $16.0^{\circ}$ was used instead of $16.4^{\circ}$. This structural correction has a $1.1^{\circ}$ standard deviation $\left(\propto_{95}=2.0^{\circ}\right)$. The structural correction and error parameters apply to the set of true mean inclinations of Hole 603B as a group, but not to comparisons within the set. Therefore, the change in apparent paleolatitude will not depend upon the accuracy of the correction for deviation of the hole from vertical.

\section{Computation of Possible Primary True Mean Inclinations}

For nearly every stage, the true mean inclination computed for the reversed-polarity samples is much shallow- 
Table 6. True mean inclinations and paleolatitudes, Sites 603 and 534.

\begin{tabular}{|c|c|c|c|c|c|c|c|c|c|}
\hline Age & Cores & Polarity & $N T / N$ & Incl. $\left({ }^{\circ}\right)$ & $\mathrm{K}$ & $\left(\propto_{95 / 63}\right)$ & $\begin{array}{l}\text { Latitude } \\
\left({ }^{\circ} \mathrm{N}\right)\end{array}$ & $\left(\propto_{95 / 63}\right)$ & $\begin{array}{c}\text { Mean } \\
\text { intensity } \\
(A / m)\end{array}$ \\
\hline \multicolumn{10}{|l|}{ Hole 603B } \\
\hline \multirow{3}{*}{ Aptian } & $40-44$ & $\mathrm{~N}$ & $30 / 29$ & 24.0 & 60 & $(3.4 / 2.0)$ & 12.5 & $(1.9 / 1.1)$ & $1.8 \mathrm{E}-3$ \\
\hline & & $\mathrm{R}$ & 1 & -41.0 & & & 23.5 & & $3.2 \mathrm{E}-2$ \\
\hline & & Vector sub. & 30 & $24.0 ?$ & & & $12.5 ?$ & & \\
\hline \multirow[t]{3}{*}{ Barrem. } & $45-61$ & $\mathrm{~N}$ & $62 / 53$ & 34.1 & 21 & $(4.3 / 2.5)$ & 18.7 & $(2.8 / 1.6)$ & $4.2 \mathrm{E}-5$ \\
\hline & & $\mathbf{R}$ & $26 / 22$ & -16.5 & 25 & $(5.9 / 3.4)$ & 8.4 & $(3.2 / 1.8)$ & $3.1 \mathrm{E}-5$ \\
\hline & & Vector sub. & 75 & 26.5 & & & 14.0 & & $3.6 \mathrm{E}-5$ \\
\hline \multirow[t]{3}{*}{ Haut. } & $62-72$ & $\mathrm{~N}$ & $66 / 61$ & 38.5 & 60 & $(2.3 / 1.3)$ & 21.7 & $(1.6 / 0.9)$ & $4.6 \mathrm{E}-5$ \\
\hline & & R & $59 / 51$ & -16.9 & 21 & $(4.3 / 2.5)$ & 8.6 & $(2.3 / 1.3)$ & $3.4 \mathrm{E}-5$ \\
\hline & & Vector sub. & 112 & 29.3 & & & 15.7 & & 3.9 E-5 \\
\hline \multirow[t]{3}{*}{ Val. } & $73-80$ & $\mathrm{~N}$ & $75 / 62$ & 48.2 & 39 & $(2.9 / 1.7)$ & 29.2 & $(2.5 / 1.4)$ & $1.7 \mathrm{E}-5$ \\
\hline & & R & $16 / 12$ & -14.8 & 14 & (11.5/6.7) & 7.6 & (6.0/3.5) & $1.5 \mathrm{E}-5$ \\
\hline & & Vector sub. & 74 & 32.4 & & & 17.6 & & $1.6 \mathrm{E}-5$ \\
\hline \multirow[t]{3}{*}{ Berr. } & $81-82$ & $\mathrm{~N}$ & $22 / 19$ & 38.9 & 98 & $(3.2 / 1.9)$ & 22.0 & $(2.3 / 1.3)$ & $8.8 \mathrm{E}-5$ \\
\hline & & $\mathrm{R}$ & $5 / 4.5$ & -13.3 & 29 & $(14.2 / 8.2)$ & 6.7 & $(7.4 / 4.3)$ & $1.9 \mathrm{E}-5$ \\
\hline & & Vector sub. & 23.5 & 34.2 & & & 18.8 & & $5.3 \mathrm{E}-5$ \\
\hline \multicolumn{10}{|l|}{ Hole $534 \mathrm{~A}$} \\
\hline \multirow[t]{3}{*}{ Barrem. } & $46-63$ & $\mathrm{~N}$ & $45 / 38$ & 32.4 & 44 & $(3.4 / 2.0)$ & 17.6 & $(2.2 / 1.3)$ & $8.6 \mathrm{E}-5$ \\
\hline & & $\mathrm{R}$ & $22 / 17$ & -25.3 & 24 & $(7.1 / 4.1)$ & 13.3 & $(4.1 / 2.4)$ & $1.5 \mathrm{E}-4$ \\
\hline & & Vector sub. & 55 & 27.9 & & & 14.8 & & $1.2 \mathrm{E}-4$ \\
\hline \multirow{3}{*}{ Haut. } & $64-72-3$ & $\mathrm{~N}$ & $65 / 49$ & 36.8 & 51 & $(2.8 / 1.6)$ & 20.5 & $(1.9 / 1.1)$ & $2.4 \mathrm{E}-5$ \\
\hline & & $\mathrm{R}$ & $21 / 17$ & -27.3 & 29 & $(6.4 / 3.7)$ & 14.5 & $(3.8 / 2.2)$ & $3.8 \mathrm{E}-5$ \\
\hline & & Vector sub. & 63 & 30.9 & & & 16.6 & & $3.1 \mathrm{E}-5$ \\
\hline \multirow[t]{3}{*}{ Val. } & $72-4-82$ & $\mathrm{~N}$ & $83 / 61$ & 35.5 & 46 & $(2.6 / 1.5)$ & 19.6 & $(1.8 / 1.0)$ & $2.2 \mathrm{E}-5$ \\
\hline & & $\mathrm{R}$ & $7 / 4$ & -34.7 & 17 & $(20.4 / 11.9)$ & 19.1 & $(13.5 / 7.8)$ & $1.4 \mathrm{E}-5$ \\
\hline & & Vector sub. & 65 & 35.1 & & & 19.4 & & $1.8 \mathrm{E}-5$ \\
\hline \multirow[t]{3}{*}{ Berr. } & $83-90$ & $\mathrm{~N}$ & $33 / 29$ & 35.9 & 72 & $(3.3 / 1.9)$ & 19.9 & $(2.2 / 1.3)$ & $1.1 \mathrm{E}-4$ \\
\hline & & $R$ & $51 / 44$ & -37.0 & 61 & $(2.9 / 1.7)$ & 20.7 & $(2.0 / 1.2)$ & 7.7 E-5 \\
\hline & & Vector sub. & & 36.3 & & & 20.2 & & $9.3 \mathrm{E}-5$ \\
\hline \multirow[t]{2}{*}{ Tith. } & $91-101$ & $\mathrm{~N}$ & $63 / 52$ & 31.6 & 61 & $(2.5 / 1.4)$ & 17.1 & $(1.6 / 0.9)$ & $5.6 \mathrm{E}-4$ \\
\hline & & $\mathrm{R}$ & $16 / 14$ & -26.0 & 35 & $(6.7 / 3.9)$ & 13.7 & $(3.9 / 2.3)$ & $7.4 \mathrm{E}-4$ \\
\hline \multirow{4}{*}{ Kimm. } & & Vector sub. & 66 & 28.4 & & & 15.1 & & $6.5 \mathrm{E}-4$ \\
\hline & $102-103$ & $\mathrm{~N}$ & $5 / 3.5$ & 17.7 & 82 & $(10.2 / 5.9)$ & 9.0 & $(5.5 / 3.2)$ & $5.2 \mathrm{E}-3$ \\
\hline & & $\mathrm{R}$ & $4 / 2.5$ & -10.9 & 125 & $(12.0 / 7.0)$ & 5.5 & $(6.2 / 3.6)$ & $1.5 \mathrm{E}-3$ \\
\hline & & Vector sub. & 6 & 16.2 & & & 8.3 & & $3.4 \mathrm{E}-3$ \\
\hline
\end{tabular}

Note: $N T / N=$ total number of samples/weighted number of samples (see text.) Incl. = mean true inclination; $\mathrm{K}=$ dispersion parameter; $\left(\propto_{95 / 63}\right)=95 \% \& 63 \%$ confidence limits. Vector sub. = mean inclination computed by subtraction of reversed polarity vector from the normal-polarity vector (see text).

er than that for the normal-polarity samples (Table 6). The average intensity of characteristic magnetization [mean of log (intensity)] for the set of reversed-polarity samples is generally much less than the average intensity for the normal-polarity set. These differences between normal and reversed-polarity results imply that secondary overprints have not been completely removed-the characteristic directions are not the primary directions of magnetization. The persistent overprints generally appear to have a normal polarity with inclinations steeper than the primary magnetization, suggesting the presence of present-day or Holocene magnetic directions or of an overprint by a downhole component induced by the drilling operation (see Ogg, 1986, for a review of the latter phenomenon in DSDP cores).

Such persistent overprints should affect the normaland reversed-polarity samples to the same degree, provided that there is no significant change in lithology and original magnetization between adjacent polarity zones. If the mean vectors of primary magnetization of the normal (N) and the reversed (R) polarity samples are antipodal and equal, in intensity $(\mathbf{N}=-\mathbf{R})$, then any uniform secondary overprint vector (S) can be removed by subtracting the observed mean magnetization vector of the reversed-polarity set (r) from the mean vector of the normal-polarity set (n):

$$
\begin{gathered}
\mathbf{n}=\mathbf{N}+\mathbf{S} ; \mathbf{r}=\mathbf{R}+\mathbf{S} \\
\therefore \mathbf{N}=(\mathbf{n}-\mathbf{r}) / 2
\end{gathered}
$$

When only inclination data are available, one must assume that all vectors are planar. This vector subtraction procedure was applied to the true mean inclination and mean intensity data for each geologic stage (Table 6).

\section{Apparent Paleolatitudes (Tithonian to Aptian)}

The paleolatitude data from the two sites imply that the western North Atlantic underwent a steady southward drift of about $6^{\circ}$ from the Berriasian to Aptian. This apparent southward drift is indicated in the differences between the computed mean paleolatitudes of each succeeding geologic stage at each site. This slow southward drift through the Early Cretaceous followed a rapid northward movement of about $5^{\circ}$ in latitude between the Tithonian and Berriasian stages, and possibly followed an earlier $7^{\circ}$ of northward motion between the Kimmeridgian and Tithonian (although the Kimmeridgian result may not be statistically significant). 
It is not possible to compare these results with the Early Cretaceous poles or polar wander path for North America. Gordon et al. (1984) estimates a 126-Ma pole at $69.9^{\circ} \mathrm{N}, 189.5^{\circ} \mathrm{E}$, but Steiner (1982) illustrates that the available Early Cretaceous paleomagnetic data set is of very poor quality; indeed, there are no reliable paleomagnetic poles for North America from lower Cretaceous rocks of a known standard geologic stage.

However, there are three main problems which bring the validity of these paleolatitudes into question. The first factor is that Site 603 is presently $7.2^{\circ}$ north of Site $534\left(35.5^{\circ} \mathrm{N}\right.$ vs $\left.28.3^{\circ} \mathrm{N}\right)$ or perhaps $4^{\circ}$ to $5^{\circ}$ north of Site 534 during the Cretaceous (computed from the pole of Gordon et al., 1984). This latitude separation is not observed in the two sets of paleolatitudes. Indeed, the Site 603 results are as much as $2^{\circ}$ south of the Site 534 paleolatitudes at each geological stage. This is probably the result of a major error in the measured or computed deviation of Hole 603B from vertical, but such a systematic error will not affect the trend in paleolatitudes. The second problem is the quality of the data. If only normal-polarity data are used, then the amount of northward drift at each site appears to be negligible or within the uncertainty of the data. The apparent northward drift is possibly an artifact of including the poorer-quality data of the reversed-polarity samples. This effect is more significant for the higher latitude of Site 603; it may, therefore, be a major cause of its apparent lack of paleolatitude separation from Site 534. The third problem is the possible shallowing of inclinations during diagenesis, a phenomenon observed in a few cases of clay-rich laminated sediments (King, 1955; Griffiths et al. 1960; Coe et al., in press); this "inclination error" may be a cause of the abnormally low paleolatitude computed for the Aptian-Albian claystones of Site 603. These three discrepancies and sources of uncertainty complicate the analysis of the paleolatitudes of these sites. Therefore, the results of both sites indicate a steady southward drift of the western North Atlantic of about $6^{\circ}$ during the Early Cretaceous, but the validity of this unexpected conclusion is uncertain.

\section{CONCLUSIONS AND SUMMARY}

The Lower Cretaceous white limestone to gray laminated marl of DSDP Sites 534 and 603 yielded a useful magnetostratigraphic record. The NRM's were dominated by a secondary normal-polarity overprint carried by goethite and/or pyrrhotite, which was removed by thermal demagnetization above $150^{\circ} \mathrm{C}$ to yield characteristic magnetizations carried primarily by magnetite. However, reversed-polarity samples generally have weaker characteristic magnetizations and shallower inclinations than normal-polarity samples. This indicates the presence of a persistent normal-polarity overprint which was apparently being removed simultaneously with the primary magnetization during demagnetization.

For each geological stage at each site, true mean inclinations and average intensities of characteristic magnetization were computed for normal-polarity and for reversed-polarity samples. Subtraction of the reversedpolarity vector from the corresponding normal-polarity vector yielded the average magnetic inclination for that stage. The Early Cretaceous paleolatitudes of each site suggest a steady southward drift of the western North Atlantic of about $6^{\circ}$, which followed rapid northward movement between the Kimmeridgian and Berriasian. In general, the sites were located at $15^{\circ}-25^{\circ} \mathrm{N}$ throughout the Early Cretaceous.

The Hauterivian-Barremian magnetostratigraphies of the sites were correlated with each other and tentatively assigned to Chrons M1 though M10N of the M-sequence block model of the Hawaiian magnetic anomaly lineations. The ages derived for the M-sequence are consistent with previous studies and with the few DSDP sites drilled on known magnetic anomalies. The Valanginian portions of Sites 534 and 603 appear to be predominantly of normal polarity, but the reliability of the characteristic magnetizations is poor because intensities are weak and a normal overprint was perhaps inadequately removed. The Valanginian magnetostratigraphies cannot be correlated between sites and do not match the M-sequence block model. The Tithonian and Berriasian magnetostratigraphy of Site 534 is correlated to Chrons M16 through M22 of the M-sequence (Ogg, 1983). The base of Hole 603B appears to be within the upper portion of reversed-polarity Chron M16.

The biostratigraphic ages assigned to reversed-polarity Chrons M0 through M19 are summarized in Table 7. These ages are based on published studies (Table 2) and on the magnetostratigraphic correlations suggested for Sites 534 and 603. A distinction is made between the biostratigraphic age assignments in different faunal zonations and the corresponding assignments to geological stages.

A particular problem at these sites is the consistent difference in the placement of the Hauterivian/Barremian boundary which is assigned according to last appearance datums and may be affected by redeposition. The dinoflagellate assignment (LAD of Druggidium apicopaucicum) places the boundary within or just above reversed-polarity Chron M7. The nannofossil biostratigraphy (LAD of Speetonia colligata according to Roth, 1983) places the boundary near the top of reversed-polarity Chron M5. This difference must be resolved by paleontologists before a standard Hauterivian/Barremian boundary can be assigned to the magnetic polarity time scale. At present, the dinoflagellate placement of the boundary seems more reliable. Magnetostratigraphic studies may eventually resolve this Hauterivian/Barremian boundary placement in the western North Atlantic DSDP sites when complete, ammonite-zoned, parastratotype land sections yield reproduceable, well-defined, magnetic polarity patterns; however, past attempts to obtain the magnetostratigraphy of such sections have been unsuccessful, therefore unpublished, (W. Lowrie, pers. comm., 1982; D. Martin, pers. comm., 1983; L. Rasplus, pers. comm., 1984; J. Vandenberg, pers. comm., 1983; Ogg, unpubl. data).

The main contribution of this study is the proposed correlations of the boundaries of the Hauterivian stage to the magnetic polarity time scale. The base of the Hauterivian, as defined by dinoflagellate biostratigraphy, is 
Table 7. Early Cretaceous magnetic polarity time scale.

\begin{tabular}{|c|c|c|c|c|c|}
\hline \multirow[b]{2}{*}{$\begin{array}{l}\text { Reversed- } \\
\text { polarity } \\
\text { zone }\end{array}$} & \multicolumn{4}{|c|}{ Biostratigraphic age assignments } & \multirow[b]{2}{*}{$\begin{array}{l}\text { Standard } \\
\text { geologic } \\
\text { stage }\end{array}$} \\
\hline & $\begin{array}{l}\text { Ammonite } \\
\text { zone/ } \\
\text { subzone }\end{array}$ & $\begin{array}{l}\text { Nannofossil } \\
\text { zone (NC)/ } \\
\text { event }\end{array}$ & $\begin{array}{l}\text { Dinoflagellate } \\
\text { events }\end{array}$ & $\begin{array}{l}\text { Calpionellid } \\
\text { zone }\end{array}$ & \\
\hline M0 & Parancycloceras bidentatum? & NC6 & & & basal Apt. \\
\hline M1 & & NC5 & & & Barrem. \\
\hline M3 & & NC5 & & & Barrem. \\
\hline M5 & & top Spectonia colligata & & & basal Barrem. \\
\hline M6 & & NC5 & & & Barrem./Haut. \\
\hline \multirow[t]{2}{*}{ M7 } & & top Cruciellipsis cuvillieri & & & \\
\hline & & $\mathrm{NC4}$ & $\begin{array}{c}\text { base Odontochitina } \\
\text { operculata, top } \\
\text { Druggidium } \\
\text { apicopaucicum }\end{array}$ & & top Haut. \\
\hline M8 & & $\mathrm{NC} 4 / 3$ & & & Haut. \\
\hline M9 & & NC3 & $\begin{array}{l}\text { base } D \text {. rhabdoreticu- } \\
\text { latum }\end{array}$ & & Haut. \\
\hline Mi0 & & $\mathrm{NC} 3$ & & & Haut. \\
\hline M10N & & $\mathrm{NC} 3$ & $\begin{array}{l}\text { top Scrinodinium } \\
\text { dictyotum, base } D \text {. } \\
\text { deflandrei }\end{array}$ & & Haut./Val. \\
\hline M11 & & $\{$ No age data for $\mathrm{M} 11$ or $\mathrm{M}$ & & & Val. \\
\hline M12 & & \{No age data for MT or $\mathrm{M}$ & & & Val. \\
\hline M13 & & & & late $\mathrm{E}$ & Val. \\
\hline M14 & $\begin{array}{l}\text { early } \text { Thurmanniceras pertransiens } \\
\text { late } T \text {. otopeta }\end{array}$ & $\mathrm{NC2}$ & base $D$. apicopaucicum & $\mathrm{E} / \mathrm{D}$ & base Val. \\
\hline M15 & early Berriasella callisto + top & $\mathrm{NC} 1$ & Biorbifera johnewingii & & . \\
\hline & Picteticeras picteti & & Zone & D & top Berr. \\
\hline M16 & $\begin{array}{l}\text { early Malbosiceras parami- } \\
\text { mounum }+ \text { Dalmasiceras } \\
\text { dalmasi }\end{array}$ & & & $\mathrm{D} / \mathrm{C}$ & late Berr. \\
\hline M17 & $\begin{array}{l}\text { Tirnovella subalpina }+ \text { late } \\
\text { Pseudosubplanites grandis }\end{array}$ & & & $\mathrm{C} / \mathrm{B}$ & early Berr. \\
\hline M18 & early $P$ grandis & $\mathrm{NCl}$ & & B & basal Berr. \\
\hline M19 & early Durangites & Conusphaera mexicana & & A & late Tith. \\
\hline
\end{tabular}

dated as within or just above reversed-polarity Chron M10N; and its top is dated as either Chron M7 or Chron M5, depending upon whether the dinoflagellate or the nannofossil definition of the Hauterivian/Barremian boundary is used.

\section{ACKNOWLEDGMENTS}

The scientific parties and technical staffs on Deep Sea Drilling Project Leg 76 and Leg 93 and the staff of the Lamont-Doherty East Coast Core Repository, especially Steve Asquith, have tolerated and greatly aided in the extensive sampling and resampling. Maureen Steiner and Peter Shive provided use of the University of Wyoming cryogenic magnetometer facilities. Tedious months of careful measuring was accomplished primarily by Beverly DeVore. Joe Kirschvink provided copies of his data analysis programs and unlimited use of his computers at the California Institute of Technology. Paleontological data, valuable insights on the reliability of different biostratigraphic zonations, and critical reviews of the magneto-biostratigraphic correlations were furnished by Timothy Bralower, Peter Roth, James Covington, Sherwood Wise, Hans Thierstein, Daniel Habib, Michel Moullade, Felix Gradstein, Dean Dunn, and Jurgen Remane. Edward Winterer provided financial, scientific, computer, and other support at the Scripps Institution of Oceanography. The manuscript was greatly improved by additional detailed reviews and critiques of the research by Edward Winterer, Massimo Sarti, James Channell, Willian Lowrie, and an anonymous reviewer. Financial support was partially provided by NSF grants EAR82-06263 for the Early Cretaceous of Leg 76 and OCE83-07771 for Mesozoic paleoceanography.

\section{REFERENCES}

Allemann, F., Catalano, R., Farès, F., and Remane, J., 1971. Standard calpionellid zonation (upper Tithonian-Valanginian) of the western Mediterranean Province In Farinacci, A. (Ed.), Proc. II
Planktonic Conference, Roma, 1970, 2: Rome (Edizioni Tecnoscienza), $1337-1340$.

Allemann, F., Grun, W., and Wiedmann, J., 1975. The Berriasian of Caravaca (Prov. of Murcia) in the subbetic zone of Spain and its importance for defining this stage and the Jurassic-Cretaceous boundary. Colloque Limite Jurassique-Crétacé, Lyon-Neuchâtel 1973. Mem. Bur. Rech. Geol. Min., 86:84-94.

Bralower, T. J., 1984. Biostratigraphic correlation of the Lower Cretaceous M-sequence in the Maiolica Limestone, Italy. Eos, 65:865. [Abstr.]

Channell, J. E. T., Lowrie, W., and Medizza, R., 1979. Middle and Early Cretaceous magnetic stratigraphy from the Cismon section, Northern Italy. Earth Planet. Sci. Lett., 42:153-166.

Cirilli, S., Márton, P., and Vigli, L., 1984. Implications of a combined biostratigraphic and palaeomagnetic study of the Umbrian Maiolica formation. Earth Planet. Sci. Lett., 69:203-214.

Coe, R. S., Globerman, B. R., Plumley, P. W., and Thrupp, G. A., in press. Paleomagnetic results from Alaska and their tectonic implications. In Howell, D. G. (Ed.), Tectonostratigraphic Terranes. Am. Assoc. Pet. Geol. Circum-Pacific Earth Sci. Ser., 1.

Cox, A., and Gordon, R. G., 1984. Paleolatitudes determined from paleomagnetic data from vertical cores. Rev. Geophys. Space Phys., 22:47-72.

Donnelly, T., Francheteau, J., Bryan, W., Robinson, P., Flower, M., Salisbury, M., et al., 1980. Init. Repts. DSDP, 51, 52, 53: Washington (U.S. Govt. Printing Office).

Galbrun, B., 1984. Magnétostratigraphie de la limite Jurassique-Crétacé. Proposition d'une échelle de polarité à partir du stratatotype du Berriasien (Berrias, Ardèche, France) et de la Sierra de Lugar (Province de Murcie, Espagne) [Thèse troisème cycle]. Univ. Pierre et Marie Curie, Paris. (Mém. Sci. Terre, 38). , 1985. Magnetostratigraphy of the Berriasian stratotype section (Berrias, France). Earth Planet Sci. Lett., 74:130-136.

Galbrun, B., and Rasplus, L., 1984. Magnétostratigraphie du stratotype du Berriasien. Premiers résultats. C. R. Acad. Sci. Paris, 298(ser. II):219-222. 
Gordon, R. G., Cox, A., and O'Hare, W. S., 1985. Paleomagnetic euler poles and the apparent polar wander and absolute motion of North America since the Carboniferous. Tectonics, 3:499-537.

Gradstein, F. M., 1983. Paleoecology and stratigraphy of Jurassic abyssal foraminifera in the Blake-Bahama Basin, Deep Sea Drilling Project Site 534. In Sheridan, R. E., Gradstein, F. M., et al., Init. Repts. DSDP, 76: Washington (U.S. Govt. Printing Office), 537-559.

Griffiths, D. H., King, R. F., Rees, A. I., and Wright, A. E., 1960. Remanent magnetism of some recent varved sediments. Proc. $R$. Soc. London, Ser. A, 256:359-383.

Habib, D., and Drugg, W. S., 1983. Dinoflagellate age of Middle Jurassic-Early Cretaceous sediments in the Blake-Bahama Basin. In Sheridan, R. E., Gradstein, F. M., et al., Init. Repts. DSDP, 76: Washington (U.S. Govt. Printing Office), 623-638.

Hailwood, E. A., 1979. Paleomagnetism of Late Mesozoic to Holocene sediments from the Bay of Biscay and Rockall Plateau, drilled on IPOD Leg 48. In Montadert, L., Roberts, D. G., et al., Init. Repts. DSDP, 48: Washington (U.S. Govt. Printing Office), 305-339.

Hailwood, E. A., Brown, C. M., and Walker, M. A., 1982. Magnetic polarity stratigraphy of some U.K. Jurassic and Cretaceous sediments. Eos, 63:1285 [Abstr.]

Hamilton, N., 1979. A paleomagnetic study of sediments from Site 397 , northwest African continental margin. In von Rad, U., Ryan, W. B. F., et al., Init. Repts. DSDP, 47, Pt. 1: Washington (U.S. Govt. Printing Office), 463-477.

Harland, W. B., Cox, A. V., Llewellyn, P. G., Pideton, C. A. G., Smith, A. G., and Walters, R., 1982. A Geologic Time Scale: Cambridge (Cambridge Univ. Press).

Henderson, J., and Davis, E., 1983. An estimate of the heat flow in the western North Atlantic at Deep Sea Drilling Project Site 534 In Sheridan, R. E., Gradstein, F. M., et al., Init. Repts. DSDP, 76: Washington (U.S. Govt. Printing Office), 719-724.

Hinte, J. E., van, 1976a. A Cretaceous time scale. Am. Assoc. Pet. Geol. Bull., 60:269-287.

1976b. A Jurassic time scale. Am. Assoc. Pet. Geol. Bull., 60:289-297.

Hollister, C. D., Ewing, J. I., et al., 1972. Init. Repts. DSDP, 11: Washington (U.S. Govt. Printing Office).

IUGS International Subcommission on Stratigraphic Classification and IUGS/IAGA Subcommission on a Magnetic Polarity Time Scale, 1979. Magnetostratigraphic polarity units-A supplementary chapter of the ISSC International Stratigraphic Guide. Geology, 7: 578-583.

Jansa, L. F., Enos, P., Tucholke, B. E., Gradstein, F. M., and Sheridan, R. E., 1979. Mesozoic-Cenozoic sedimentary formations of the North American Basin; western North Atlantic. In Talwani, M., Hay, W., and Ryan, W. B. F. (Eds.), Deep Drilling Results in the Atlantic Ocean: Continental Margins and Paleoenvironment. Am. Geophys. Un., Maurice Ewing Ser., 3:1-58.

Keating, B. H., and Helsley, C. E., 1978a. Magnetostratigraphy of Cretaceous age sediments from Sites 361, 363, and 364. In Bolli, H. M., Ryan, W. B. F., et at., Init. Repts. DSDP, 40: Washington (U.S. Govt. Printing Office), 459-467.

1978b. Magnetostratigraphic studies of Cretaceous sediments from DSDP Site 369. In Lancelot, Y., Seibold, E., et al., Init. Repts. DSDP, Suppl. to vols. 38, 39, 40, and 41: Washington (U.S. Govt. Printing Office), 983-986.

1978c. Paleomagnetic results from DSDP Hole 391C and the magnetostratigraphy of Cretaceous sediments from the Atlantic Ocean floor. In Benson, W. E., Sheridan, R. E., et al., Init. Repts. DSDP, 44: Washington (U.S. Govt. Printing Office), 523-528.

1979. Magnetostratigraphy of Cretaceous sediments from DSDP Site 386. In Tucholke, B. E., Vogt, P. R., et al., Init. Repts. DSDP, 43: Washington (U.S. Govt. Printing Office), 781-784.

Kelts, K., and Giovanoli, G., 1980. Paleomagnetic directions from Lower Cretaceous interpillow limestones, Deep Sea Drilling Project Leg 51, Hole 417D, Bermuda Rise. In Donnelly, T., Francheteau, J., Bryan, W., Robinson, P., Flower, M., Salisbury, M., et al., Init. Repts. DSDP, 51, 52, 53, Pt. 2: Washington (U.S. Govt. Printing Office), 1429-1430.
Kent, D. V., and Gradstein, F. M., 1985. A Cretaceous and Jurassic geochronology. Geol. Soc. Am. Bull., 96:1419-1427.

Kent, D. V., and Lan, P. T., 1978. Paleomagnetism and rock magnetism of Upper Jurassic limestone and basalt from Site 367. In Lancelot, Y., Seibold, E., et al., Init. Repts. DSDP, Suppl. to Vols. $38,39,40$, and 41 : Washington (U.S. Govt. Printing Office), $995-$ 1002 .

King, R. F., 1955. Remanent magnetism of artificially deposited sediments. Monthly Notices R. Astron. Soc., Geophys. Suppl., 7: 115-134.

Kirschvink, J. L., 1980. The least-squares line and plane and the analysis of palaeomagnetic data. Geophy. J. R. Astron. Soc., 62: 699-718.

Klitgord, K. D., and Schouten, H., in press. Plate kinematics of the Central Atlantic. In Tucholke, B. E., and Vogt, P.R. (Eds.), The Geology of North America: The Western Atlantic Region. Geol. Soc. Am. Decade of North American Geology Ser., 1.

Kono, M., 1980a. Paleomagnetism of DSDP Leg 55 basalts and implications for the tectonics of the Pacific plate. In Jackson, E. D., Koizumi, I., et al., Init. Repts. DSDP, 55:Washington (U.S. Govt. Printing Office), 737-752.

1980b. Statistics of paleomagnetic inclination data. J. Geophys. Res., 85:3878-3882.

LaBrecque, J. L., Hsü, K. J., Carman M. F., Jr., Karpoff, A.-M., McKenzie, J. A., Percival, S. F., Jr., Peterson, N. P., Pisciotto, K. A., Schreiber, E., Tauxe, L., Tucker, P., Weissert, H. J., and Wright, R., 1983. DSDP Leg 73: contributions to Paleogene stratigraphy in nomenclature, chronology and sedimentation rates. Paleogeogr., Paleoclimatol., Paleoecol., 42:91-125.

Lancelot, Y., Hathaway, J. C., and Hollister, C. D., 1972. Lithology of sediments from the western North Atlantic. In Hollister, C. D., Ewing, J. I., et al., Init. Repts. DSDP, 11: Washington (U.S. Govt. Printing Office), 901-949.

Larson, R. L., and Hilde, T. W. C., 1975. A revised time scale of magnetic reversals for the Early Cretaceous and Late Jurassic. J. Geophys. Res., 80:2586-2594.

Larson, R. L., Moberly, R., et al., 1975. Init. Repts. DSDP, 32: Washington (U.S. Govt. Printing Office).

Larson, R. L., and Pitman, W. C., III, 1972. World-wide correlation of Mesozoic magnetic anomalies and its implications. Geol. Soc. Am. Bull., 83:3645-3662.

Le Hégarat, G., 1973. Le Berriasien du Sud-Est de la France. Doc. Lab. Geol. Fac. Sci. Lyon, 43.

, 1980. Le Berriasien. Les Etages Français et Leurs Stratotypes. Mem. Bur. Rech. Geol., 109:96-105.

Le Hégarat, G., and Remane, J., 1968. Tithonique supérieur et Berriasien de la bordure cévenole. Corrélation des ammonites et des calpionelles. Géobios (Fac. Sci. Lyon), 1:7-70.

Lowrie, W., and Alvarez, W., 1984. Lower Cretaceous magnetic stratigraphy in Umbrian pelagic limestone sections. Earth Planet. Sci. Lett., 71:315-328.

Lowrie, W., Alvarez, W., Premoli Silva, I., and Monechi, S., 1980. Lower Cretaceous magnetic stratigraphy in Umbrian pelagic carbonate rocks. Geophys. J. R. Astron. Soc., 60:263-281.

Lowrie, W., and Channell, J. E. T., 1984a. Magnetostratigraphy of the Jurassic-Cretaceous boundary in the Maiolica limestone (Umbria, Italy). Geology, 12:44-47. $1984 \mathrm{~b}$. Reply on "Magnetostratigraphy of the JurassicCretaceous boundary in the Maiolica limestone (Umbria, Italy)." Geology, 12:702.

Lowrie, W., Channell, J. E. T., and Alvarez, W., 1980. A review of magnetic stratigraphy investigations in Cretaceous pelagic carbonate rocks. J. Geophys. Res., 85:3597-3605.

Lowrie, W., and Heller, F., 1982. Magnetic properties of marine limestones. Rev. Geophys. Space Phy., 20:171-192.

Lowrie, W., and Ogg, J. G., 1986. A magnetic polarity time scale for the Early Cretaceous and Late Jurassic. Earth Planet. Sci. Lett., 76:341-349.

McFadden, P. L., and Reid, A. B., 1982. Analysis of palaeomagnetic inclination data. Geophys. J. R. Astron. Soc., 69:307-319.

Márton, E., 1982. Late Jurassic/Early Cretaceous magnetic stratigraphy from the Sumëg section, Hungary. Earth Planet. Sci. Lett., 57:182-190. 
Micarelli, A., Potette, M., and Chiochini, M., 1977. Ricerche microbiostratigrafiche sulla Maiolica della region umbromarchigiana. Stud. Geol. Camerti, 3:57-86.

Morgan, G. E., 1979. Paleomagnetic results from DSDP Site 398. In Sibuet, J. -C., Ryan, W. B. F., et al., Init. Repts. DSDP, 47, Pt. 2: Washington (U.S. Govt. Printing Office), 599-611.

Ogg, J. G., 1981. Sedimentology and paleomagnetism of Jurassic pelagic limestones [Ph.D. dissert.]. Scripps Institution of Oceanography, University of California, San Diego.

1983. Magnetostratigraphy of Upper Jurassic and lowest Cretaceous sediments, Deep Sea Drilling Project Site 534, western North Atlantic. In Sheridan, R. E., Gradstein, F. M., et al., Init. Repts. DSDP, 76: Washington (U.S. Govt. Printing Office), 685697.

1984. Comment on "Magnetostratigraphy of Jurassic-Cretaceous boundary in the Maiolica limestone (Umbria, Italy." Geology, 12:701-702.

1986. Paleolatitudes and magnetostratigraphy of Cretaceous and lower Tertiary sedimentary rocks, Deep Sea Drilling Project Site 585, east Mariana Basin, western Central Pacific. In Moberly, R., Schlanger, S. O., et al., Init. Repts. DSDP, 89: Washington (U.S. Govt. Printing Office), 629-646.

Ogg, J. G., and Lowrie, W., 1986. Magnetostratigraphy of the Jurassic-Cretaceous boundary. Geology., 14:547-550.

Ogg, J. G., Robertson, A. H. F., and Jansa, L. F., 1983. Jurassic sedimentation history of Site 534 (western North Atlantic) and of the Atlantic-Tethys seaway. In Sheridan, R. E., Gradstein, F. M., et al., Init. Repts. DSDP, 76: Washington (U.S. Govt. Printing Office), 829-884

Ogg, J. G., and Steiner, M. B., 1985. Jurassic magnetic polarity time scale: current status and compilation. In Michelson, O., and Zeiss, A. (Eds.) International Symposium on Jurassic Stratigraphy (Vol. 3), Erlangen, Germany, Sept. 1-8, 1984: Copenhagen (Geological Survey of Denmark), 777-794.

Ogg, J. G., Steiner, M. B., Oloriz, F., and Tavera, J. M., 1984. Jurassic magnetostratigraphy: 1. Kimmeridgian-Tithonian of Sierra Gorda and Carcabuey, southern Spain. Earth Planet. Sci. Lett., 71: $147-162$.

Okada, H., and Thierstein, H. R., 1979. Calcareous nannoplanktonLeg 43, Deep Sea Drilling Project. In Tucholke, B. E., Vogt, P. R., et al., Init. Repts. DSDP, 43: Washington (U.S. Govt. Printing Office), 507-573.

Oloriz, F., and Tavera, J. M., 1981. El Tithonico en la Zona Subbetica. Cuad. Geol. Univ. Granada, 10:489-508.

J. M., 1982. Correlation of the Tithonian in the central sector of the Betic Cordilleras (Spain) in the light of recent studies. Bull. Acad. Polon. Sci., Ser. Sci. Terre, 30:145-156.

Remane, J., 1978. Calpionellids. In Haq, B. U., and Boersma, A. (Eds.), Introduction to Marine Micropaleontology: New York (Elsevier), pp. 161-170.

1983. Calpionellids and the Jurassic/Cretaceous boundary at Deep Sea Drilling Project Site 534, western North Atlantic Ocean. In Sheridan, R. E., Gradstein, F. M., et al.,Init. Repts. DSDP, 76: Washington (U.S. Govt. Printing Office), 561-567.

Robertson, A. H. F., and Bliefnick, D. M., 1983. Sedimentology and origin of Lower Cretaceous pelagic carbonates and redeposited clastics, Blake-Bahama Formation, Deep Sea Drilling Project Site 534, western equatorial Atlantic. In Sheridan, R. E., Gradstein, F. M., et al., Init. Repts. DSDP, 76: Washington (U.S. Govt. Printing Office), 795-828.

Roth, P. H., 1978. Cretaceous nannoplankton biostratigraphy and oceanography of the northwestern Atlantic Ocean. In Benson, W. E., Sheridan, R. E., et al., Init. Repts. DSDP, 44: Washington (U.S. Govt. Printing Office), 731-759.

1983. Jurassic and Lower Cretaceous calcareous nannofossils in the western North Atlantic (Site 534): biostratigraphy, preservation, and some observations on biogeography and paleoceanography. In Sheridan, R. E., and Gradstein, F. M., et al., Init. Repts. DSDP, 76: Washington (U.S. Govt. Printing Office), 587621.
Schouten, H., and Klitgord, K. D., 1977. Map showing Mesozoic magnetic anomalies, western North Atlantic. U.S Geol. Surv. Misc. Field Studies Map MF-915.

1982. The memory of the accreting plate boundary and the continuity of fracture zones. Earth Planet. Sci. Lett., 59:255-266.

Sheridan, R. E., Bates, L. G., Shipley, T. H., and Crosby, J. T., 1983. Seismic stratigraphy in the Blake-Bahama Basin and the origin of Horizon D. In Sheridan, R. E., Gradstein, F. M., et al., Init. Repts. DSDP, 76: Washington (U.S. Govt. Printing Office), 667-683.

Sheridan, R. E., Gradstein, F. M.., et al., 1983. Site 534: Blake-Bahama Basin. In Sheridan, R. E., Gradstein, F. M., et al., Init. Repts. DSDP, 76: Washington (U.S. Govt. Printing Office), 141-340.

Steiner, M. B., 1977. Magnetization of Jurassic red deep-sea sediments in the Atlantic (DSDP Site 105). Earth Planet Sci. Lett., 35: 205-214.

1982. Mesozoic plate motions of North America. In Reynolds, M. W., and Dolly, E.D. (Eds.), Mesozoic Paleogeography of the West-Central United States: Denver (Rocky Mountain Section, Soc. Econ. Paleontol. Mineral.), pp. 1-11.

Thierstein, H. R., 1973. Lower Cretaceous calcareous nannoplankton zonation. Abh. Geol. Bundesanst. (Wien), 29:1-52.

Tucholke, B. E., 1981. Geologic significance of seismic reflectors in the deep western North Atlantic Basin. In Warme, J. E., Douglas, R. G., and Winterer, E.L. (Eds.), The Deep Sea Drilling Project: $A$ Decade of Progress. Soc. Econ. Paleontol. Mineral. Spec. Publ., 32:23-37.

Tucholke, B. E., Vogt, P. R., et al., 1979. Init. Repts. DSDP, 43: Washington (U.S. Govt. Printing Office).

Vogt, P. R., Anderson, C. N., and Bracey, D. R., 1971. Mesozoic magnetic anomalies, sea-floor spreading, and geomagnetic reversals in the southwestern North Atlantic. J. Geophys. Res., 76: 4796-4823.

Vogt, P. R., and Einwich, A. M., 1979. Magnetic amomalies and seafloor spreading in the western North Atlantic, and a revised calibration of the Keathley (M) geomagnetic reversal chronology. In Tucholke, B. E., Vogt, P. R., et al., Init. Repts. DSDP, 43: Washington (U.S. Govt. Printing Office), 857-876.

Winterer, E. L., Ewing, J. I., et al., 1973. Init. Repts. DSDP, 17: Washington (U.S. Govt. Printing Office).

Zeiss, A., 1983. Zur Frage der Äquivalenz der Stufen Tithon/Berrias/ Portland in Eurasien und Amerika. Ein Beitrag zur Klärung der weltweiten Korrelation der Jura/Kreide. Grenzschichten im marine Bereich. Zitteliana, 10:427-438.

Date of Initial Receipt: 2 April 1985

Date of Acceptance: 21 January 1986

\section{APPENDIX A \\ Paleomagnetic Study of Nineteen Cretaceous Samples from Hole 603B \\ G. Canninga, Paleomagnetic Laboratory "Fort Hoofddyk"1}

Nineteen samples from Cores $603 \mathrm{~B}-38$ to -41 were progressively demagnetized, using both thermal ( 5 samples) and AF demagnetization treatments. Initial measurements revealing the direction and intensity of NRM are shown in Appendix Table 1, together with the directions of the high-coercivity remanences, which were derived from the demagnetization diagrams (e.g., Appendix Fig. 1).

The samples are oriented up and down only, so only the inclinations from the directions of magnetization could be used to establish the polarity of the samples. The inclinations of the high coercivity remanences all have normal polarity. Shipboard paleontology indicated an Aptian-Albian age for these samples, so they probably fall within the long interval of normal magnetic polarity during the Cretaceous.

\footnotetext{
1 Address: Paleomagnetic Laboratory "Fort Hoofddyk," Budapestlaan 17, $3584 \mathrm{CD}$ Utrecht, The Netherlands.
} 
Table 1. Paleomagnetic results, Cores $603 \mathrm{~B}-38$ to -41 .

\begin{tabular}{|c|c|c|c|c|}
\hline \multirow[b]{2}{*}{$\begin{array}{l}\text { Core-Section } \\
\text { (interval in } \mathrm{cm} \text { ) }\end{array}$} & \multicolumn{2}{|c|}{ NRM } & \multirow[b]{2}{*}{$\begin{array}{l}\text { High-coerciv. rem. } \\
\text { (dec/inc) }\end{array}$} & \multirow[b]{2}{*}{$\begin{array}{l}\text { Position } \\
\text { (m) }\end{array}$} \\
\hline & $\begin{array}{l}\text { Direction } \\
\text { (dec/inc) }\end{array}$ & $\frac{\text { Intensity }}{\left(\mathrm{A} / \mathrm{m} \times 10^{-6}\right)}$ & & \\
\hline $38-1,123$ & $50^{\circ} /+55^{\circ}$ & 1311 & $89^{\circ} /+59^{\circ}$ & 1164.93 \\
\hline $38-2,116$ & $31 /+58$ & 1308 & $97 /+67$ & 1166.16 \\
\hline $38-3,091$ & $100 /+67$ & 5556 & $166 /+38$ & 1167.41 \\
\hline $38-4,007$ & $293 /+48$ & 11244 & $248 /+40$ & 1168.07 \\
\hline $39-1,118$ & $269 /+62$ & 6620 & $209 /+49$ & 1173.68 \\
\hline $39-2,002$ & $280 /+65$ & 5311 & $205 /+35$ & 1174.02 \\
\hline $39-2,129$ & $57 /+64$ & 2161 & $112 /+48$ & 1175.29 \\
\hline $39-3,117$ & $11 /+51$ & 1193 & $359 /+64$ & 1175.67 \\
\hline $39-5,95$ & $127 /+70$ & 1915 & $153 /+59$ & 1179.45 \\
\hline $40-1,109$ & $36 /+55$ & 5768 & $90 /+58$ & 1182.59 \\
\hline $40-2,21$ & $66 /+62$ & 5135 & $131 /+54$ & 1183.21 \\
\hline $40-3,9$ & $127 /+62$ & 1830 & $160 /+36$ & 1184.59 \\
\hline $40-4,29$ & $45 /+60$ & 2332 & $80 /+59$ & 1186.29 \\
\hline $40-5,123$ & $195 /+61$ & 74191 & $187 /+37$ & 1188.73 \\
\hline $40-6,49$ & $316 /+53$ & 172137 & $291 /+46$ & 1189.49 \\
\hline $41-1,131$ & $348 /+50$ & 148792 & $349 /+37$ & 1191.81 \\
\hline $41-2,138$ & $235 /+52$ & 10636 & $217 /+37$ & 1193.38 \\
\hline $41-3,91$ & $45 /+69$ & 16549 & $174 /+35$ & 1194.41 \\
\hline $41-4,82$ & $229 /+67$ & 187781 & $184 /+35$ & 1195.82 \\
\hline
\end{tabular}
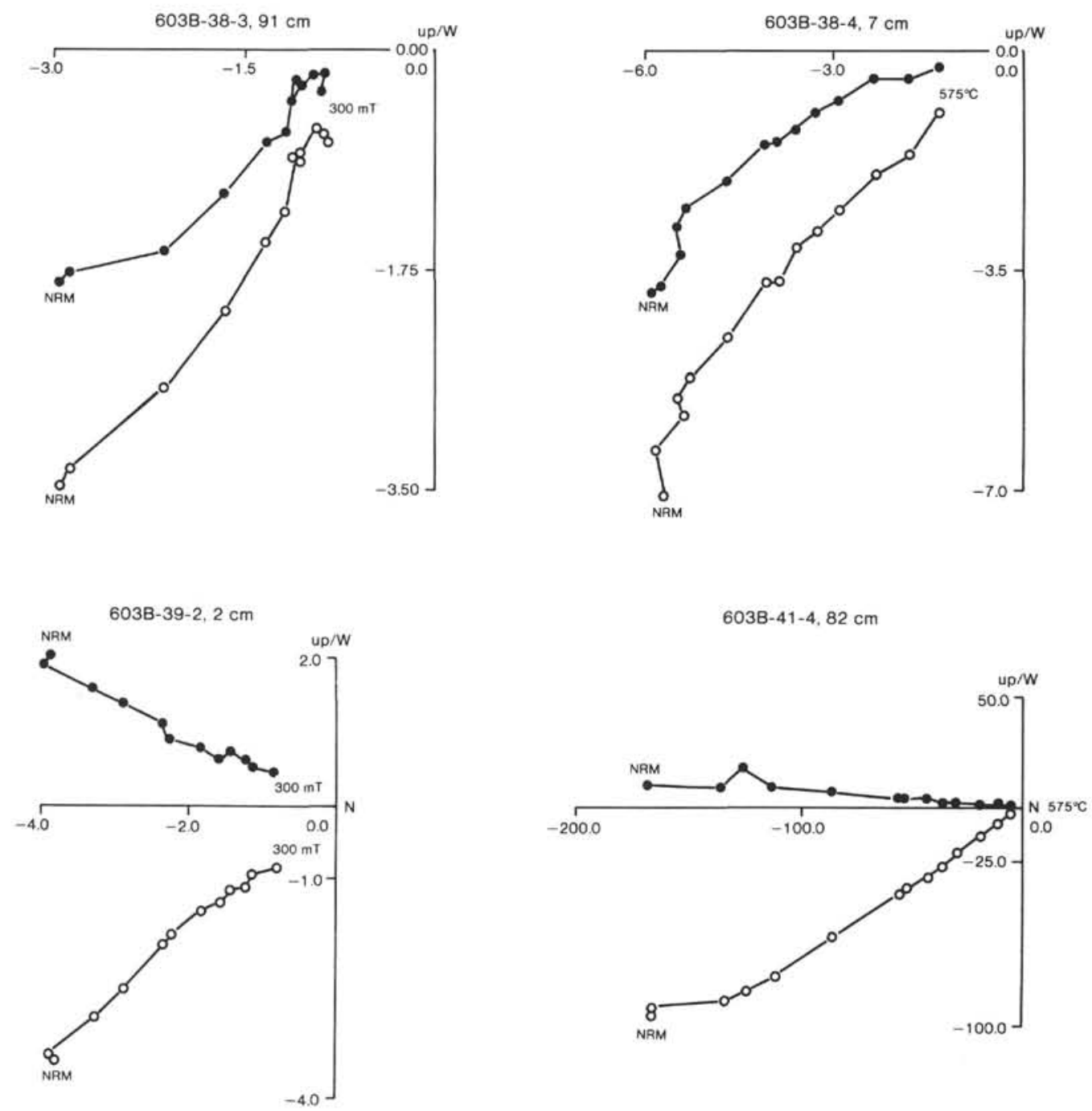

Figure 1. Demagnetization diagrams. Samples 603B-38-3, $91 \mathrm{~cm}$ and 603B-39-2, $2 \mathrm{~cm}$ underwent progressive AF demagnetization $(0,5,15,25,40,60,100,150(2 \times), 200,250$, and $300 \mathrm{mT}$. Samples 603B-38-4, $7 \mathrm{~cm}$ and $603 \mathrm{~B}-41-4,82 \mathrm{~cm}$ were thermally demagnetized $\left(20^{\circ}, 50^{\circ}, 100^{\circ}, 125^{\circ}, 150^{\circ}, 175^{\circ}, 200^{\circ}, 225^{\circ}, 300^{\circ}, 350^{\circ}\right.$, $425^{\circ}, 500^{\circ}$, and $575^{\circ} \mathrm{C}$ ). Each diagram shows vertical (open symbols) and horizontal (closed symbols) projection of vector points which represent the remanent magnetization at different demagnetization steps. Units are in $10^{-3} \mathrm{~A} / \mathrm{m}$. 
APPENDIX B

Directions of Characteristic Magnetization, DSDP Hole 534A: Early Cretaceous-Latest Jurassic

\begin{tabular}{|c|c|c|c|c|c|c|c|c|c|}
\hline $\begin{array}{l}\text { Core-Section } \\
\text { (interval in } \mathrm{cm} \text { ) }\end{array}$ & $\begin{array}{l}\text { Sub-bottom } \\
\text { depth } \\
\text { (m) }\end{array}$ & Mean incl. ${ }^{\mathrm{a}}$ & Pol. int. ${ }^{b}$ & $\begin{array}{c}\text { Mean } \\
\text { intensity } \\
\left(\mathrm{emu} / \mathrm{cm}^{3}\right)\end{array}$ & $\begin{array}{l}\text { Core-Section } \\
\text { (interval in } \mathrm{cm} \text { ) }\end{array}$ & $\begin{array}{l}\text { Sub-bottom } \\
\text { depth } \\
\text { (m) }\end{array}$ & Mean incl. ${ }^{a}$ & Pol. int. ${ }^{b}$ & $\begin{array}{c}\text { Mean } \\
\text { intensity } \\
\left(\mathrm{emu} / \mathrm{cm}^{3}\right)\end{array}$ \\
\hline $46-1,60$ & 941.60 & $20.0^{\circ}$ & NOP & 9.6 E-9 & $59-4,10$ & 1058.10 & -17.1 & REP & $4.6 \mathrm{E}-8$ \\
\hline $46-1,112$ & 942.12 & -54.3 & $\mathrm{R}$ ? & $5.3 \mathrm{E}-9$ & $60-1,34$ & 1062.84 & 1.8 & INT & 4.1 E-8 \\
\hline $47-1,122$ & 951.22 & 35.9 & $\mathrm{~N}$ & 9.1 E-9 & $60-1,127$ & 1063.77 & -65.0 & REP & 7.2 E-8 \\
\hline $47-2,117$ & 952.67 & -21.2 & REP & 8.8 E-9 & $60-2,119$ & 1065.19 & -13.8 & $\mathrm{R}$ & $7.1 \mathrm{E}-7$ \\
\hline $47-3,27$ & 953.27 & 33.8 & $\mathrm{~N}$ & $2.7 \mathrm{E}-8$ & $60-3,12$ & 1065.62 & 6.2 & INT & 7.0 E-7 \\
\hline $47-4,112$ & 955.62 & 35.5 & NOP & 3.1 E-9 & $60-3,28$ & 1065.78 & -37.5 & $\mathrm{R}$ & $2.1 \mathrm{E}-6$ \\
\hline $48-1,46$ & 956.46 & 11.6 & $\mathrm{R}$ ? & 6.9 E-9 & $60-3,109$ & 1066.59 & -20.1 & R & 6.5 E-7 \\
\hline $48-1,127$ & 957.27 & 56.1 & INT & 5.8 E-9 & $60-4,29$ & 1067.29 & -23.2 & R & $3.4 \mathrm{E}-7$ \\
\hline $48-2,35$ & 957.85 & 8.2 & REP & 3.4 E-9 & $60-4,117$ & 1068.17 & -16.1 & $\mathrm{R}$ & 9.4 E-6 \\
\hline $48-3,38$ & 959.38 & 5.0 & $\mathrm{R}$ ? & 4.3 E-9 & $61-1,46$ & 1071.96 & -13.1 & $\mathrm{R}$ & $4.3 \mathrm{E}-7$ \\
\hline $48-4,34$ & 960.84 & 45.5 & INT & 2.5 E-9 & $61-1,123$ & 1072.73 & -44.8 & $\mathrm{R}$ & $5.8 \mathrm{E}-8$ \\
\hline $48-5,26$ & 962.26 & 42.2 & INT & 2.7 E-9 & $61-2,31$ & 1073.31 & 11.7 & $\mathrm{~N}$ & $2.0 \mathrm{E}-7$ \\
\hline $48-6,12$ & 963.62 & 42.6 & NOP & 6.5 E-9 & $61-2,120$ & 1074.20 & 32.9 & $\mathrm{~N}$ & $3.7 \mathrm{E}-7$ \\
\hline $49-1,46$ & 963.96 & 30.1 & $\mathrm{R}$ ? & $1.7 \mathrm{E}-8$ & $61-3,15$ & 1074.65 & 21.0 & $\mathrm{~N}$ & $1.0 \mathrm{E}-5$ \\
\hline $49-2,04$ & 965.04 & -39.4 & REP & 4.5 E-9 & $61-4,68$ & 1076.68 & 22.1 & $\mathrm{~N}$ & 2.1 E-6 \\
\hline $49-2,134$ & 966.34 & 58.2 & $\mathrm{R}$ ? & 3.1 E-9 & $61-5,55$ & 1078.05 & 29.5 & $\mathrm{~N}$ & $5.3 \mathrm{E}-6$ \\
\hline $49-3,11$ & 966.61 & -4.2 & INT & 3.5 E-9 & $62-1,7$ & 1080.57 & 13.0 & $\mathrm{~N}$ & $5.9 \mathrm{E}-7$ \\
\hline $49-4,12$ & 968.12 & 20.8 & NOP & $3.8 \mathrm{E}-9$ & $62-1,60$ & 1081.10 & 28.4 & $\mathrm{~N}$ & $3.3 \mathrm{E}-6$ \\
\hline $49-5,120$ & 970.70 & 4.2 & INT & 2.9 E-9 & $63-1,45$ & 1089.95 & $\begin{array}{l}20.4 \\
18.9\end{array}$ & $\mathrm{~N}$ & 8.7 E-6 \\
\hline $49-6,111$ & 972.11 & -49.8 & REP & 4.8 E-9 & $63-1,117$ & 1090.67 & -28.6 & $\mathrm{R}$ & 2.5 E-6 \\
\hline $49-7,1$ & 972.51 & 66.3 & $\mathrm{R}$ ? & 4.5 E-9 & $63-2,31$ & 1091.31 & 29.4 & $\mathrm{~N}$ & $1.1 \mathrm{E}-7$ \\
\hline $50-1,116$ & 973.66 & -27.7 & REP & 4.4 E-9 & $63-2,71$ & 1091.71 & -16.4 & $\mathrm{R}$ & $1.2 \mathrm{E}-7$ \\
\hline $50-2,91$ & 974.91 & 29.3 & NOP & 3.1 E-9 & $63-3,5$ & 1092.55 & -20.7 & $\mathrm{R}$ & $1.9 \mathrm{E}-7$ \\
\hline $50-3,39$ & 975.89 & 21.2 & NOP & $1.3 \mathrm{E}-8$ & $63-3,58$ & 1093.08 & -5.5 & $\mathrm{R}$ & $2.2 \mathrm{E}-7$ \\
\hline $50-4,65$ & 977.65 & 30.8 & NOP & 5.3 E-9 & $64-1,6$ & 1098.56 & -41.3 & $\mathrm{R}$ & $1.5 \mathrm{E}-7$ \\
\hline $50-5,39$ & 978.89 & -70.1 & $\mathrm{R}$ ? & 7.5 E-9 & $64-1,111$ & 1099.61 & -29.4 & $\mathbf{R}$ & $5.4 \mathrm{E}-8$ \\
\hline $51-1,13$ & 981.65 & 8.9 & $\mathrm{R}$ ? & 5.0 E-9 & $64-2,61$ & 1100.61 & -34.8 & $\mathrm{R}$ & 8.5 E- 8 \\
\hline $51-1,89$ & 982.39 & -36.7 & REP & $1.6 \mathrm{E}-8$ & $64-2,125$ & 1101.25 & -21.3 & $\mathbf{R}$ & $6.0 \mathrm{E}-8$ \\
\hline $51-1,116$ & 982.66 & 48.9 & NOP & 5.5 E-9 & $64-3,67$ & 1102.70 & -27.7 & REP & $1.3 \mathrm{E}-8$ \\
\hline $52-1,48$ & 990.48 & 34.9 & $\mathrm{~N}$ & 7.4 E-8 & $64-4,54$ & 1103.54 & -53.8 & R & $2.3 \mathrm{E}-8$ \\
\hline $52-1,131$ & 991.81 & 45.2 & $\mathrm{~N}$ & 2.8 E- 8 & $64-4,102$ & 1104.02 & -42.5 & $\mathrm{R}$ & 6.1 E-9 \\
\hline $52-2,95$ & 992.95 & 37.0 & $\mathrm{~N}$ & $1.1 \mathrm{E}-7$ & $65-1,72$ & 1108.22 & -6.7 & $\mathrm{R}$ & $1.2 \mathrm{E}-7$ \\
\hline $52-3,32$ & 993.82 & 42.8 & $\mathrm{~N}$ & 5.3 E-8 & $65-1,124$ & 1108.74 & -30.6 & $\mathrm{R}$ & 8.0 E-8 \\
\hline $52-3,142$ & 994.92 & 37.2 & $\mathrm{~N}$ & 2.7 E- 8 & $65-2,81$ & 1109.81 & -20.2 & R & $1.2 \mathrm{E}-7$ \\
\hline $52-4,109$ & 996.09 & 33.6 & $\mathrm{~N}$ & $1.4 \mathrm{E}-8$ & $65-3,129$ & 1111.79 & -21.2 & REP & 2.2 E-8 \\
\hline $52-5,42$ & 996.92 & 35.6 & $\mathrm{~N}$ & 9.5 E-9 & $65-4,93$ & 1112.93 & 23.3 & $\mathrm{~N}$ & 8.0 E-8 \\
\hline $52-5,134$ & 997.84 & 56.1 & $\mathrm{~N}$ & 9.6 E-9 & $65-5,26$ & 1113.76 & 24.5 & $\mathrm{~N}$ & $1.2 \mathrm{E}-7$ \\
\hline $53-1,93$ & 1000.43 & 34.3 & $\mathrm{~N}$ & $1.7 \mathrm{E}-8$ & $65-5,123$ & 1114.73 & 21.3 & NOP & $1.9 \mathrm{E}-8$ \\
\hline $53-2,68$ & 1001.68 & 37.8 & $\mathrm{~N}$ & 7.6 E-9 & $65-6,74$ & 1115.74 & 35.6 & NOP & 4.6 E-8 \\
\hline $53-3,25$ & 1002.75 & 32.2 & $\mathrm{~N}$ & $1.7 \mathrm{E}-8$ & $66-1,29$ & 1116.79 & 30.3 & $\mathrm{~N}$ & $1.0 \mathrm{E}-7$ \\
\hline $53-3,102$ & 1003.52 & 22.7 & $\mathrm{~N}$ & 8.9 E-9 & $66-1,145$ & 1117.95 & 39.8 & $\mathrm{~N}$ & $6.3 \mathrm{E}-8$ \\
\hline $53-4,98$ & 1004.98 & 44.0 & $\mathrm{~N}$ & 6.9 E-9 & $66-2,67$ & 1118.67 & 42.2 & NOP & 3.5 E-8 \\
\hline $53-5,23$ & 1005.73 & 46.6 & $\mathrm{~N}$ & $1.7 \mathrm{E}-8$ & $66-2,142$ & 1119.42 & 33.2 & $\mathrm{~N}$ & $6.0 \mathrm{E}-8$ \\
\hline $54-1,40$ & 1008.90 & -32.1 & REP & 5.0 E-9 & $66-3,39$ & 1119.89 & 28.8 & $\mathrm{~N}$ & $1.5 \mathrm{E}-7$ \\
\hline $54-1,123$ & 1009.73 & 47.8 & INT & 3.2 E-9 & $66-3,95$ & 1120.45 & 47.2 & NOP & $1.0 \mathrm{E}-8$ \\
\hline $54-2,27$ & 1010.27 & 44.8 & INT & 2.6 E-9 & $66-4,44$ & 1121.44 & 43.2 & $\mathrm{~N}$ & $1.5 \mathrm{E}-7$ \\
\hline $54-2,119$ & 1011.19 & -41.3 & $\mathrm{R}$ & $5.5 \mathrm{E}-8$ & $66-4,114$ & 1122.14 & 32.5 & $\mathrm{~N}$ & $1.2 \mathrm{E}-7$ \\
\hline $54-3,57$ & 1012.07 & -26.7 & REP & 3.6 E-9 & $66-5,6$ & 1122.56 & 23.3 & $\mathrm{~N}$ & $3.8 \mathrm{E}-7$ \\
\hline $55-1,75$ & 1018.25 & 14.5 & REP & 7.9 E-9 & $67-1,19$ & 1125.69 & -25.6 & $\mathrm{R}$ & $3.3 \mathrm{E}-8$ \\
\hline $55-1,135$ & 1018.85 & 6.2 & REP & 5.5 E-9 & $67-1,51$ & 1126.01 & -20.4 & REP & $1.4 \mathrm{E}-8$ \\
\hline $55-2,84$ & 1020.57 & 25.2 & $\mathrm{~N}$ & $1.1 \mathrm{E}-8$ & $67-1,123$ & 1126.73 & -37.6 & R & 3.9 E-8 \\
\hline $55-3,7$ & 1020.57 & 25.2 & $\mathrm{~N}$ & 6.1 E-8 & $67-2,3$ & 1127.03 & -10.6 & REP & 8.4 E-9 \\
\hline $55-3,93$ & 1021.43 & 26.4 & NOP & $1.3 \mathrm{E}-8$ & $67-2,57$ & 1127.57 & 54.1 & INT & 6.3 E-9 \\
\hline $55-4,14$ & 1022.14 & 60.2 & $\mathrm{R}$ ? & 7.5 E-9 & $67-2,134$ & 1128.34 & 38.6 & NOP & 2.7 E- 8 \\
\hline $56-1,16$ & 1026.66 & -17.7 & $\mathrm{R}$ ? & 4.6 E-9 & $67-3,33$ & 1128.83 & 37.0 & NOP & 7.3 E-9 \\
\hline $56-1,60$ & 1027.10 & 56.0 & INT & 4.3 E-9 & $67-3,105$ & 1129.55 & 26.8 & $\mathrm{~N}$ & $1.3 \mathrm{E}-8$ \\
\hline $56-2,97$ & 1028.97 & 24.0 & NOP. & $1.2 \mathrm{E}-8$ & $67-4,9$ & 1130.09 & 33.0 & $\mathrm{~N}$ & $1.7 \mathrm{E}-8$ \\
\hline $56-3,29$ & 1029.79 & 37.6 & $\mathrm{~N}$ & 7.1 E-8 & $68-1,17$ & 1130.17 & 30.7 & $\mathrm{~N}$ & $2.0 \mathrm{E}-8$ \\
\hline $56-3,86$ & 1030.39 & 36.3 & $\mathrm{~N}$ & 4.8 E-8 & $68-1,66$ & 1130.66 & 41.3 & NOP & $1.8 \mathrm{E}-8$ \\
\hline $57-4,115$ & 1041.15 & 46.3 & N? & 3.1 E-9 & $68-1,111$ & 1131.11 & 63.7 & $\mathrm{R}$ ? & $1.6 \mathrm{E}-8$ \\
\hline $57-4,128$ & 1041.28 & 18.4 & $\mathrm{~N}$ ? & 7.2 E-9 & $68-2,38$ & 1131.88 & 37.7 & NOP & 9.8 E-9 \\
\hline $58-1,31$ & 1044.80 & 42.3 & $\mathrm{~N}$ & $1.5 \mathrm{E}-6$ & $68-2,99$ & 1132.49 & 39.0 & $\mathrm{~N}$ & 2.4 E- 8 \\
\hline $58-1,47$ & 1044.97 & -12.7 & $\mathrm{R}$ & $3.0 \mathrm{E}-7$ & $68-2,147$ & 1132.97 & 41.5 & $\mathrm{~N}$ & $1.0 \mathrm{E}-8$ \\
\hline $58-2,101$ & 1047.01 & 23.0 & REP & $2.8 \mathrm{E}-7$ & $68-3,16$ & 1133.16 & 10.8 & NOP & 4.6 E-8 \\
\hline $58-3,23$ & 1047.73 & 38.1 & REP & $1.0 \mathrm{E}-7$ & $68-3,95$ & 1133.95 & 44.7 & NOP & $1.8 \mathrm{E}-8$ \\
\hline $58-3,143$ & 1048.93 & 44.5 & $\mathrm{~N}$ & $1.3 \mathrm{E}-6$ & $68-4,14$ & 1134.64 & 26.2 & $\mathrm{~N}$ & 2.5 E-8 \\
\hline $58-4,86$ & 1049.86 & 43.6 & $\mathrm{~N}$ & $1.8 \mathrm{E}-6$ & $68-4,61$ & 1135.11 & 45.1 & $\mathrm{~N}$ & $1.6 \mathrm{E}-8$ \\
\hline $58-4,137$ & 1050.37 & -1.6 & $\mathrm{R}$ ? & 3.1 E-8 & $68-4,140$ & 1135.90 & -17.4 & REP & 9.6 E-9 \\
\hline $58-5,50$ & 1051.00 & 26.8 & $\mathrm{~N}$ & $1.9 \mathrm{E}-7$ & $68-5,5$ & 1136.05 & 35.8 & $\mathrm{~N}$ & 5.5 E-8 \\
\hline $59-1,7$ & 1053.57 & 38.5 & $\mathrm{~N}$ & $5.0 \mathrm{E}-6$ & $68-5,51$ & 1136.51 & 45.0 & $\mathrm{~N}$ & $1.7 \mathrm{E}-8$ \\
\hline $59-1,138$ & 1054.88 & 21.4 & $\mathrm{~N}$ & 4.3 E-8 & $68-5,97$ & 1136.97 & 46.4 & NOP & 6.2 E-9 \\
\hline $59-2,45$ & 1055.45 & 69.5 & INT & $6.5 \mathrm{E}-7$ & $68-6,8$ & 1137.58 & 26.2 & NOP & $5.8 \mathrm{E}-8$ \\
\hline $59-3,16$ & 1056.66 & -20.5 & REP & 6.1 E-8 & $68-6,71$ & 1138.21 & 34.9 & NOP & $1.7 \mathrm{E}-8$ \\
\hline $59-3,92$ & 1057.42 & 19.3 & $\mathrm{R}$ ? & 2.7 E-8 & $69-1,29$ & 1139.29 & 31.9 & NOP & $1.2 \mathrm{E}-7$ \\
\hline $59-3,143$ & 1057.93 & 34.1 & $\mathrm{~N}$ ? & $3.2 \mathrm{E}-8$ & $69-1,75$ & 1139.75 & 37.7 & $\mathrm{~N}$ & $2.6 \mathrm{E}-8$ \\
\hline
\end{tabular}


Appendix B (continued).

\begin{tabular}{|c|c|c|c|c|c|c|c|c|c|}
\hline $\begin{array}{l}\text { Core-Section } \\
\text { (interval in } \mathrm{cm} \text { ) }\end{array}$ & $\begin{array}{l}\text { Sub-bottom } \\
\text { depth } \\
\text { (m) }\end{array}$ & Mean incl. ${ }^{\mathrm{a}}$ & Pol. int. ${ }^{b}$ & $\underset{\text { intensity }}{\text { Mean }}$ & $\begin{array}{l}\text { Core-Section } \\
\text { (interval in } \mathrm{cm} \text { ) }\end{array}$ & $\begin{array}{l}\text { Sub-bottom } \\
\text { depth } \\
\text { (m) }\end{array}$ & Mean incl. ${ }^{a}$ & Pol. int. ${ }^{b}$ & $\begin{array}{c}\text { Mean } \\
\text { intensity } \\
\left(\mathrm{emu} / \mathrm{cm}^{3}\right)\end{array}$ \\
\hline $69-2,41$ & 1140.91 & 66.0 & NOP & 1.4 E-8 & $74-5,35$ & 1190.75 & 42.2 & $\mathrm{~N}$ & $1.8 \mathrm{E}-8$ \\
\hline $69-2,125$ & 1141.75 & 45.6 & NOP & $1.7 \mathrm{E}-8$ & $74-5,73$ & 1190.75 & 28.2 & NOP & $1.7 \mathrm{E}-8$ \\
\hline $69-3,54$ & 1142.54 & 28.7 & NOP & $2.0 \mathrm{E}-8$ & $74-6,14$ & 1191.64 & 53.3 & NOP & $1.0 \mathrm{E}-8$ \\
\hline $69-3,131$ & 1143.31 & 29.7 & $\mathrm{~N}$ & $1.5 \mathrm{E}-8$ & $74-6,78$ & 1192.28 & 36.8 & N? & 8.5 E-9 \\
\hline $69-4,27$ & 1143.77 & 26.9 & NOP & $7.0 \mathrm{E}-9$ & $75-1,31$ & 1193.31 & 9.0 & INT & $1.3 \mathrm{E}-8$ \\
\hline $69-4,127$ & 1144.77 & 44.4 & $N$ & $1.9 \mathrm{E}-8$ & $75-1,91$ & 1193.91 & 56.0 & NOP & $1.3 \mathrm{E}-8$ \\
\hline $69-5,41$ & 1145.41 & 33.9 & NOP & 7.0 E-8 & $75-2,16$ & 1194.66 & 40.9 & $\mathrm{~N}$ & $1.8 \mathrm{E}-8$ \\
\hline $69-5,101$ & 1146.01 & 57.9 & NOP & 2.0 E-8 & $75-2,93$ & 1195.43 & 35.6 & NOP & $1.1 \mathrm{E}-8$ \\
\hline $69-6,8$ & 1146.58 & 42.1 & $\mathrm{~N}$ & $1.9 \mathrm{E}-8$ & $75-2,126$ & 1195.76 & 58.4 & INT & $3.0 \mathrm{E}-9$ \\
\hline $69-6,109$ & 1147.59 & 35.5 & $\mathrm{~N}$ & 4.2 E-8 & $75-3,34$ & 1196.34 & 31.5 & NOP & 6.5 E-9 \\
\hline $69-7,13$ & 1148.00 & 32.6 & $\mathrm{~N}$ & 8.0 E-9 & $75-3,38$ & 1196.38 & 34.6 & NOP & $1.0 \mathrm{E}-8$ \\
\hline $70-1,37$ & 1148.37 & 26.9 & $\mathrm{~N}$ & 3.6 E-8 & $75-3,99$ & 1196.99 & 35.1 & NOP & 9.0 E-9 \\
\hline $70-1,118$ & 1149.18 & 34.7 & $\mathrm{~N}$ & $1.4 \mathrm{E}-8$ & $75-4,24$ & 1197.74 & 27.0 & NOP & 5.0 E-9 \\
\hline $70-2,71$ & 1150.21 & 41.3 & $\mathrm{~N}$ & 8.5 E-9 & $75-4,109$ & 1198.59 & 50.8 & NOP & $1.0 \mathrm{E}-8$ \\
\hline $70-3,5$ & 1151.05 & 49.4 & $\mathrm{~N}$ & $1.1 \mathrm{E}-8$ & $75-5,19$ & 1199.19 & 36.7 & $\mathrm{~N}$ & $1.2 \mathrm{E}-8$ \\
\hline $70-3,75$ & 1151.75 & 57.5 & NOP & $1.4 \mathrm{E}-8$ & $75-5,63$ & 1199.63 & 25.0 & INT & 2.1 E-9 \\
\hline $70-3,121$ & 1152.21 & 41.8 & $\mathrm{~N}$ & 1.4 E-8 & $75-5,114$ & 1200.14 & 42.7 & INT & 4.4 E-9 \\
\hline $70-4,31$ & 1152.81 & 46.6 & $\mathrm{~N}$ ? & 5.1 E-9 & $75-6,23$ & 1200.73 & 31.5 & NOP & 9.4 E-9 \\
\hline $70-4,90$ & 1153.40 & 28.2 & $\mathrm{~N}$ ? & 5.8 E-9 & $75-6,45$ & 1200.95 & 12.0 & $\mathrm{~N} ?$ & 5.6 E-9 \\
\hline $70-4,144$ & 1153.94 & 62.1 & INT & 9.0 E-9 & $75-6,108$ & 1201.58 & 43.2 & $\mathrm{~N}$ & $2.3 \mathrm{E}-8$ \\
\hline $70-5,64$ & 1154.69 & 44.2 & $\mathrm{~N}$ & 1.7 E-8 & $76-1,27$ & 1202.27 & 56.7 & N? & $1.6 \mathrm{E}-8$ \\
\hline $70-5,88$ & 1154.88 & 47.5 & $\mathrm{~N}$ & $1.9 \mathrm{E}-8$ & $76-1,105$ & 1203.05 & 56.9 & NOP & $1.3 \mathrm{E}-8$ \\
\hline $70-5,126$ & 1155.26 & -17.9 & $\mathrm{R}$ ? & 8.0 E-9 & $76-2,97$ & 1204.47 & 31.7 & $\mathrm{~N}$ & $4.7 \mathrm{E}-8$ \\
\hline $70-6,5$ & 1155.55 & 44.2 & NOP & 3.5 E-9 & $76-3,31$ & 1205.31 & 53.8 & $\mathrm{~N}$ & 6.8 E-9 \\
\hline $70-6,42$ & 1155.92 & 43.2 & $\mathrm{~N}$ & 7.7 E-9 & $76-3,116$ & 1206.16 & 55.4 & NOP & 2.4 E- 8 \\
\hline $71-1,43$ & 1157.43 & 47.9 & $\mathrm{~N}$ & $1.3 \mathrm{E}-8$ & $76-4,11$ & 1206.61 & 33.5 & $\mathrm{~N}$ & $3.2 \mathrm{E}-8$ \\
\hline $71-1,92$ & 1157.43 & 42.0 & $\mathrm{~N}$ & $1.3 \mathrm{E}-8$ & $76-4,115$ & 1207.65 & 24.1 & $\mathrm{~N}$ & 2.1 E-8 \\
\hline $71-2,3$ & 1158.53 & 41.3 & $\mathrm{~N}$ & $1.2 \mathrm{E}-8$ & $76-5,11$ & 1208.11 & 26.2 & $\mathrm{~N}$ & $1.0 \mathrm{E}-8$ \\
\hline $71-2,96$ & 1159.46 & 40.4 & $\mathrm{~N}$ & 2.4 E-8 & $76-5,54$ & 1208.54 & 49.1 & INT & 2.9 E-9 \\
\hline $71-3,4$ & 1160.04 & 42.7 & $\mathrm{~N}$ & $1.2 \mathrm{E}-8$ & $76-5,106$ & 1209.06 & 38.3 & NOP & 8.0 E-9 \\
\hline $71-3,99$ & 1160.99 & 21.3 & NOP & $1.1 \mathrm{E}-8$ & $76-6,24$ & 1209.74 & 18.9 & $\mathrm{~N}$ & $3.2 \mathrm{E}-8$ \\
\hline $71-4,30$ & 1161.80 & 41.0 & $\mathrm{~N}$ & 8.7 E-9 & $76-6,85$ & 1210.35 & 29.3 & $\mathrm{~N}$ & $6.2 \mathrm{E}-8$ \\
\hline $71-4,120$ & 1162.52 & 21.8 & $\mathrm{~N}$ & 1.1 E-8 & $77-1,40$ & 1211.40 & 31.0 & $\mathrm{~N}$ & $8.8 \mathrm{E}-8$ \\
\hline $71-5,16$ & 1163.16 & 21.0 & NOP & 5.8 E-9 & $77-1,93$ & 1211.93 & 27.3 & $\mathrm{~N}$ & $1.8 \mathrm{E}-8$ \\
\hline $71-5,114$ & 1164.14 & 56.1 & NOP & $1.9 \mathrm{E}-8$ & $77-2,13$ & 1212.63 & 36.7 & NOP & 9.1 E-9 \\
\hline $71-6,19$ & 1164.69 & -4.1 & $\mathrm{R}$ ? & $1.2 \mathrm{E}-8$ & $77-2,83$ & 1213.33 & 36.1 & $\mathrm{~N}$ & $2.9 \mathrm{E}-8$ \\
\hline $72-1,20$ & 1166.20 & 33.3 & $\mathrm{~N}$ & 2.7 E-8 & $77-3,22$ & 1214.22 & 31.7 & $\mathrm{~N}$ & 2.2 E- 8 \\
\hline $72-1,83$ & 1166.83 & 32.9 & NOP & 4.4 E-9 & $77-3,94$ & 1214.94 & 30.9 & NOP & $1.4 \mathrm{E}-8$ \\
\hline $72-1,141$ & 1167.41 & 37.5 & INT & 5.8 E-9 & $77-4,30$ & 1215.80 & 35.1 & NOP & $6.0 \mathrm{E}-8$ \\
\hline $72-2,15$ & 1167.65 & -35.1 & $\mathrm{R}$ ? & 3.2 E-9 & $78-1,23$ & 1216.00 & 44.3 & $\mathrm{~N}$ & $3.3 \mathrm{E}-8$ \\
\hline $72-2,60$ & 1168.10 & 1.5 & REP & 2.7 E- 8 & $78-1,97$ & 1216.10 & 35.0 & $\mathrm{~N}$ & $1.1 \mathrm{E}-7$ \\
\hline $72-2,114$ & 1168.64 & -5.2 & REP & 2.1 E-8 & $78-1,127$ & 1216.27 & 25.2 & NOP & 8.0 E- 8 \\
\hline $72-3,36$ & 1169.36 & 31.3 & NOP & 3.3 E-8 & $78-2,31$ & 1216.81 & -43.7 & REP & $4.8 \mathrm{E}-9$ \\
\hline $72-3,84$ & 1169.84 & -32.4 & $\mathrm{R}$ & 3.9 E-8 & $78-2,109$ & 1217.59 & 5.7 & $\mathrm{R}$ ? & 4.9 E-9 \\
\hline $72-3,121$ & 1170.21 & -11.7 & REP & 2.4 E- 8 & $78-2,144$ & 1217.94 & 36.7 & N? & 2.4 E- 8 \\
\hline $72-4,5$ & 1170.55 & -8.8 & REP & 5.3 E-9 & $78-3,21$ & 1218.21 & -21.4 & $\mathrm{R}$ ? & $1.3 \mathrm{E}-8$ \\
\hline $72-4,59$ & 1171.09 & 22.8 & REP & 4.3 E-9 & $78-3,63$ & 1218.63 & 17.4 & INT & 1.9 E-9 \\
\hline $72-4,113$ & 1171.63 & -19.7 & REP & 8.0 E-9 & $78-3,130$ & 1219.30 & 22.3 & $\mathrm{~N}$ & 3.0 E-8 \\
\hline $72-4,146$ & 1171.96 & 32.0 & $\mathrm{~N}$ ? & 9.5 E-9 & $78-4,38$ & 1219.88 & 29.5 & $\mathrm{~N}$ & $3.0 \mathrm{E}-8$ \\
\hline $72-5,29$ & 1172.29 & 28.3 & $N$ & 2.0 E-8 & $78-4,140$ & 1220.90 & 23.4 & $\mathrm{~N}$ & $5.7 \mathrm{E}-8$ \\
\hline $72-5,71$ & 1172.71 & 34.7 & $\mathrm{~N}$ & $1.6 \mathrm{E}-8$ & $78-5,45$ & 1221.45 & 23.3 & NOP & 5.4 E-8 \\
\hline $72-5,118$ & 1173.18 & 31.5 & NOP & 7.1 E-9 & $78-5,122$ & 1222.22 & 27.4 & $\mathrm{~N}$ & $3.6 \mathrm{E}-8$ \\
\hline $72-6,35$ & 1173.85 & 12.1 & INT & 7.1 E-9 & $78-6,10$ & 1222.60 & 33.3 & NOP & $1.1 \mathrm{E}-8$ \\
\hline $72-6,77$ & 1174.27 & 24.2 & $\mathrm{~N}$ & $6.8 \mathrm{E}-8$ & $79-1,8$ & 1224.58 & 17.9 & NOP & $5.0 \mathrm{E}-8$ \\
\hline $73-1,11$ & 1175.11 & 52.0 & $\mathrm{~N}$ & $1.5 \mathrm{E}-8$ & $79-1,117$ & 1225.67 & 22.2 & $\mathrm{~N}$ & 3.0 E- 8 \\
\hline $73-1,68$ & 1175.68 & 37.4 & $\mathrm{~N}$ & $1.3 \mathrm{E}-8$ & $79-2,25$ & 1226.25 & 33.1 & $\mathrm{~N}$ & $3.0 \mathrm{E}-8$ \\
\hline $73-1,123$ & 1176.23 & 37.4 & $\mathrm{~N}$ & 3.7 E-8 & $79-2,115$ & 1227.15 & 26.0 & $\mathrm{~N}$ & $2.7 \mathrm{E}-8$ \\
\hline $73-2,20$ & 1176.70 & 59.0 & $\mathrm{~N}$ & $1.4 \mathrm{E}-8$ & $79-3,45$ & 1227.93 & 34.1 & NOP & 8.4 E-9 \\
\hline $73-2,68$ & 1177.18 & 38.7 & $\mathrm{~N}$ & 5.5 E-8 & $79-3,107$ & 1228.57 & 32.5 & NOP & $3.8 \mathrm{E}-8$ \\
\hline $73-2,136$ & 1177.86 & 40.5 & NOP & $1.4 \mathrm{E}-8$ & $79-4,52 \mathrm{~A}$ & 1229.52 & 34.9 & $\mathrm{~N}$ ? & $4.8 \mathrm{E}-8$ \\
\hline $73-3,26$ & 1178.26 & 33.9 & $\mathrm{~N}$ & $2.3 \mathrm{E}-8$ & $79-4,52 \mathrm{~B}$ & 1229.52 & 40.6 & $\mathrm{~N}$ ? & 8.5 E-8 \\
\hline $73-3,140$ & 1179.40 & 30.2 & NOP & $1.0 \mathrm{E}-8$ & $79-4,136$ & 1230.36 & 42.8 & NOP & $5.2 \mathrm{E}-8$ \\
\hline $73-4,35$ & 1179.85 & 23.9 & NOP & $1.2 \mathrm{E}-8$ & $79-5,56$ & 1231.06 & 35.0 & $\mathrm{~N}$ & $4.2 \mathrm{E}-8$ \\
\hline $73-4,109$ & 1180.59 & 40.2 & NOP & 2.7 E-8 & $79-5,137$ & 1231.87 & 33.1 & NOP & $1.7 \mathrm{E}-8$ \\
\hline $73-5,12$ & 1181.12 & 60.2 & $\mathrm{~N}$ & 7.9 E-8 & $79-6,45$ & 1232.45 & 61.0 & NOP & 8.2 E-9 \\
\hline $73-5,59$ & 1181.59 & 48.7 & $\mathrm{~N}$ & $1.7 \mathrm{E}-8$ & $80-1,17$ & 1233.67 & -43.9 & $\mathrm{R}$ & $1.1 \mathrm{E}-8$ \\
\hline $73-5,91$ & 1181.91 & 58.8 & NOP & $1.0 \mathrm{E}-8$ & $80-1,120$ & 1234.70 & 38.9 & INT & 3.9 E-9 \\
\hline $74-1,12$ & 1184.12 & 41.1 & $\mathrm{~N}$ & $1.7 \mathrm{E}-8$ & $80-2,4$ & 1235.04 & 43.6 & NOP & 4.8 E-9 \\
\hline $74-1,91$ & 1184.91 & 45.4 & NOP & $2.8 \mathrm{E}-8$ & $80-2,89$ & 1235.89 & 42.7 & $N ?$ & 6.5 E-9 \\
\hline $74-2,54$ & 1186.04 & 30.0 & $\mathrm{~N}$ & $1.7 \mathrm{E}-8$ & $80-3,14 \mathrm{~A}$ & 1236.64 & -7.6 & $\mathrm{R}$ ? & $6.2 \mathrm{E}-8$ \\
\hline $74-2,126$ & 1186.76 & 34.5 & $\mathrm{~N}$ & $3.0 \mathrm{E}-8$ & $80-3,14 \mathrm{~B}$ & 1236.64 & -45.0 & REP & $1.3 \mathrm{E}-8$ \\
\hline $74-3,9$ & 1187.09 & 37.0 & $\mathrm{~N}$ & 2.8 E-8 & $80-5,14$ & 1239.64 & -36.0 & REP & 8.8 E-9 \\
\hline $74-4,97$ & 1187.97 & 64.5 & NOP & $5.7 \mathrm{E}-9$ & $80-5,86$ & 1240.36 & 26.6 & $\mathrm{~N} ?$ & 4.5 E-9 \\
\hline $74-4,28$ & 1188.78 & 26.2 & NOP & 6.6 E-9 & $80-5,132$ & 1240.82 & 35.6 & $\mathrm{~N}$ & 1.7 E-8 \\
\hline $74-4,121$ & 1189.71 & 46.9 & $\mathrm{~N}$ & $1.7 \mathrm{E}-8$ & $81-1,51$ & 1243.01 & 30.0 & $\mathrm{~N}$ & $2.5 \mathrm{E}-8$ \\
\hline
\end{tabular}


Appendix B (continued).

\begin{tabular}{|c|c|c|c|c|c|c|c|c|c|}
\hline $\begin{array}{l}\text { Core-Section } \\
\text { (interval in } \mathrm{cm} \text { ) }\end{array}$ & $\begin{array}{l}\text { Sub-bottom } \\
\text { depth } \\
\text { (m) }\end{array}$ & Mean incl. ${ }^{a}$ & Pol. int. ${ }^{b}$ & $\begin{array}{c}\text { Mean } \\
\text { intensity } \\
\left(\mathrm{emu} / \mathrm{cm}^{3}\right)\end{array}$ & $\begin{array}{l}\text { Core-Section } \\
\text { (interval in } \mathrm{cm} \text { ) }\end{array}$ & $\begin{array}{l}\text { Sub-bottom } \\
\text { depth } \\
\text { (m) }\end{array}$ & Mean incl. ${ }^{a}$ & Pol. int. ${ }^{b}$ & $\begin{array}{c}\text { Mean } \\
\text { intensity } \\
\left(\mathrm{emu} / \mathrm{cm}^{3}\right)\end{array}$ \\
\hline $81-1,89$ & 1243.39 & 46.8 & NOP & 6.9 E-9 & $83-3,133 \mathrm{~B}$ & 1308.33 & 44.6 & INT & $7.6 \mathrm{E}-8$ \\
\hline $81-2,41$ & 1244.41 & 49.4 & NOP & $1.0 \mathrm{E}-8$ & $88-4,54$ & 1309.04 & -45.1 & $\mathrm{R}$ & $1.6 \mathrm{E}-7$ \\
\hline $81-2,128$ & 1245.28 & 43.7 & $\mathrm{~N}$ ? & 6.4 E-9 & $88-4,130$ & 1309.80 & -32.3 & $\mathrm{R}$ & 6.4 E-8 \\
\hline $81-3,124$ & 1246.74 & 41.4 & $\mathrm{~N}$ & $1.3 \mathrm{E}-8$ & $88-5,46$ & 1310.46 & -40.7 & $\mathrm{R}$ & $4.8 \mathrm{E}-8$ \\
\hline $81-4,55$ & 1247.55 & 43.9 & NOP & $1.0 \mathrm{E}-8$ & $88-5,142$ & 1311.42 & -43.0 & $\mathrm{R}$ & $1.0 \mathrm{E}-7$ \\
\hline $81-4,147$ & 1248.47 & -25.7 & REP & 5.6 E-9 & $88-6,24$ & 1311.74 & -37.0 & $\mathrm{R}$ & $1.6 \mathrm{E}-7$ \\
\hline $82-1,90$ & 1252.40 & 23.8 & $\mathrm{~N}$ ? & 3.8 E-9 & $89-1,24$ & 1313.24 & -26.1 & $\mathrm{R}$ & 5.3 E-8 \\
\hline $82-1,142$ & 1252.92 & 33.7 & NOP & 7.9 E-9 & $89-1,133$ & 1314.33 & 38.9 & $\mathrm{~N}$ & $5.5 \mathrm{E}-8$ \\
\hline $82-2,20$ & 1253.20 & 43.5 & NOP & $1.7 \mathrm{E}-8$ & $89-2,014$ & 1314.64 & 50.9 & $\mathrm{~N}$ & 5.6 E-8 \\
\hline $82-2,42$ & 1253.42 & 32.6 & NOP & 3.4 E-9 & $89-2,140$ & 1315.90 & 36.9 & $N$ & 9.2 E-8 \\
\hline $82-2,66$ & 1253.66 & 23.2 & N? & 4.3 E-9 & $89-3,43$ & 1316.43 & 35.3 & $\mathrm{~N}$ & $1.4 \mathrm{E}-7$ \\
\hline $83-1,4$ & 1260.54 & 23.4 & N? & 3.1 E-8 & $89-3,128$ & 1317.28 & 52.3 & $\mathrm{~N}$ & $7.7 \mathrm{E}-8$ \\
\hline $83-1,115$ & 1261.65 & -39.3 & $\mathrm{R}$ & $9.1 \mathrm{E}-8$ & $89-4,40$ & 1317.90 & 35.6 & $\mathrm{~N}$ & $3.4 \mathrm{E}-7$ \\
\hline $83-2,17$ & 1262.17 & -18.3 & REP & 1.1 E-8 & $89-4,109$ & 1318.59 & 31.2 & $\mathrm{~N}$ & $5.5 \mathrm{E}-7$ \\
\hline $83-2,121 \mathrm{~A}$ & 1263.21 & -11.6 & REP & 2.2 E-8 & $89-5,15$ & 1319.15 & 32.8 & $\mathrm{~N}$ & 1.6 E-7 \\
\hline $83-2,121 B$ & 1263.21 & 58.0 & INT & $4.5 \mathrm{E}-8$ & $89-5,104$ & 1320.04 & 36.0 & $\mathrm{~N}$ & $1.6 \mathrm{E}-7$ \\
\hline $83-3,15$ & 1263.65 & 43.3 & $\mathrm{~N}$ & $4.2 \mathrm{E}-8$ & $89-6,4$ & 1320.40 & 35.0 & NOP & $1.0 \mathrm{E}-7$ \\
\hline $83-3,72$ & 1264.22 & 30.9 & $\mathrm{~N}$ & $4.2 \mathrm{E}-8$ & $90-1,37$ & 1322.37 & 37.3 & $\mathrm{~N}$ & 9.3 E-8 \\
\hline $83-4,15$ & 1265.15 & 20.4 & $\mathrm{~N}$ ? & $2.8 \mathrm{E}-8$ & $90-1,102$ & 1323.02 & 39.7 & NOP & $1.1 \mathrm{E}-7$ \\
\hline $83-4,67$ & 1265.67 & 25.4 & $\mathrm{~N}$ & $7.5 \mathrm{E}-8$ & $90-2,37 \mathrm{~A}$ & 1323.87 & -40.2 & REP & 6.1 E-8 \\
\hline $83-4,110$ & 1266.10 & 36.1 & NOP & $1.5 \mathrm{E}-7$ & $90-2,37 \mathrm{~B}$ & 1323.87 & 60.4 & INT & $1.8 \mathrm{E}-7$ \\
\hline $83-5,14$ & 1266.64 & 36.5 & $\mathrm{~N}$ & $4.2 \mathrm{E}-7$ & $90-2,108$ & 1324.58 & -36.9 & $\mathrm{R}$ & $1.0 \mathrm{E}-7$ \\
\hline $83-5,98$ & 1267.45 & 27.1 & $\mathrm{~N}$ & 1.4 E-6 & $90-3,41$ & 1325.41 & -45.5 & $\mathrm{R}$ & 6.0 E-8 \\
\hline $83-5,141$ & 1267.91 & 28.4 & $\mathrm{~N}$ & 4.4 E- 6 & $90-3,97$ & 1325.97 & -35.6 & $\mathrm{R}$ & 8.5 E- 8 \\
\hline $84-1,14$ & 1268.14 & 29.2 & NOP & 9.7 E-9 & $90-4,15$ & 1326.65 & -34.2 & $\mathrm{R}$ & 6.7 E-8 \\
\hline $84-1,101$ & 1269.01 & 31.0 & $\mathrm{~N}$ & $1.8 \mathrm{E}-7$ & $90-4,118$ & 1327.68 & -45.2 & $\mathrm{R}$ & $1.4 \mathrm{E}-7$ \\
\hline $84-2,34$ & 1269.84 & -19.6 & REP & 2.7 E-8 & $90-5,38$ & 1328.38 & -42.3 & $\mathrm{R}$ & $1.1 \mathrm{E}-7$ \\
\hline $84-2,112$ & 1270.62 & -24.5 & REP & 7.2 E-8 & $90-5,117$ & 1329.17 & 36.3 & NOP & $3.5 \mathrm{E}-8$ \\
\hline $84-3,27$ & 1271.27 & -18.7 & REP & $5.8 \mathrm{E}-8$ & $91-1,26$ & 1331.26 & 42.5 & $\mathrm{~N}$ & $1.0 \mathrm{E}-7$ \\
\hline $84-3,107$ & 1272.07 & -22.5 & REP & $7.9 \mathrm{E}-8$ & $91-1,96$ & 1331.96 & 37.3 & $\mathrm{~N}$ & 2.3 E-7 \\
\hline $84-4,30$ & 1272.80 & -25.9 & REP & $1.2 \mathrm{E}-7$ & $91-2,22$ & 1332.72 & 32.3 & $\mathrm{~N}$ & $6.3 \mathrm{E}-7$ \\
\hline $84-4,104$ & 1273.54 & -34.9 & REP & $3.0 \mathrm{E}-8$ & $91-2,97$ & 1333.47 & -34.1 & $\mathbf{R}$ & 7.3 E-8 \\
\hline $84-5,23$ & 1274.23 & -28.7 & $\mathrm{R}$ & 8.6 E-8 & $91-3,08$ & 1334.08 & 45.7 & $\mathrm{~N}$ & 9.5 E-8 \\
\hline $84-5,110$ & 1275.10 & -29.3 & $\mathrm{R}$ & $1.1 \mathrm{E}-7$ & $91-3,109$ & 1335.09 & 42.6 & $\mathrm{~N}$ & 9.2 E-8 \\
\hline $84-6,32$ & 1275.82 & -32.4 & REP & $2.2 \mathrm{E}-7$ & $91-4,21$ & 1335.71 & 38.1 & $\mathrm{~N}$ & $1.2 \mathrm{E}-7$ \\
\hline $84-6,109$ & 1276.59 & -15.5 & $\mathrm{R}$ ? & $1.0 \mathrm{E}-8$ & $91-4,118$ & 1336.68 & 42.4 & $\mathrm{~N}$ & $1.0 \mathrm{E}-7$ \\
\hline $84-7,34$ & 1277.34 & 30.7 & $\mathrm{~N}$ & $2.6 \mathrm{E}-8$ & $91-5,35$ & 1337.35 & 39.9 & $\mathrm{~N}$ & $7.0 \mathrm{E}-8$ \\
\hline $85-1,13$ & 1277.40 & 36.5 & $\mathrm{~N}$ & $4.3 \mathrm{E}-8$ & $91-5,108$ & 1338.08 & 39.4 & $\mathrm{~N}$ & 6.6 E- 8 \\
\hline $85-1,107$ & 1278.07 & 44.4 & NOP & $2.3 \mathrm{E}-8$ & $91-6,31$ & 1338.81 & 41.2 & $\mathrm{~N}$ & 9.5 E-8 \\
\hline $85-2,30$ & 1278.80 & 36.0 & $\mathrm{~N}$ & $6.0 \mathrm{E}-8$ & $92-1,19$ & 1340.19 & 31.5 & $\mathrm{~N}$ & 3.1 E-7 \\
\hline $85-2,115$ & 1279.65 & 39.5 & $\mathrm{~N}$ & 7.1 E-8 & $92-1,119$ & 1341.19 & 28.3 & $\mathrm{~N}$ & 7.0 E-7 \\
\hline $85-3,21 \mathrm{~A}$ & 1280.21 & 13.1 & NOP & $4.6 \mathrm{E}-8$ & $92-2,16$ & 1341.66 & 31.2 & $\mathrm{~N}$ & 7.1 E-7 \\
\hline $85-3,21 \mathrm{~B}$ & 1280.21 & 27.2 & NOP & $9.6 \mathrm{E}-8$ & $92-2,79$ & 1342.29 & 45.4 & NOP & $1.4 \mathrm{E}-7$ \\
\hline $85-3,106$ & 1281.06 & 32.5 & $\mathrm{~N}$ & $1.0 \mathrm{E}-7$ & $92-2,143$ & 1342.93 & 34.4 & $\mathrm{~N}$ & 3.0 E-7 \\
\hline $85-4,32$ & 1281.82 & 41.0 & $\mathrm{~N}$ & 8.4 E- 8 & $92-3,40$ & 1343.40 & 35.6 & $\mathrm{~N}$ & $9.5 \mathrm{E}-7$ \\
\hline $85-4,115$ & 1282.65 & 37.9 & $\mathrm{~N}$ & $2.2 \mathrm{E}-7$ & $92-3,115$ & 1344.15 & 31.6 & $\mathrm{~N}$ & 4.4 E-7 \\
\hline $85-5,22$ & 1283.22 & 37.8 & $\mathrm{~N}$ & 6.4 E-8 & $92-4,6$ & 1344.56 & 27.0 & $\mathrm{~N}$ & 8.3 E-7 \\
\hline $85-5,91$ & 1283.91 & -30.8 & REP & $2.3 \mathrm{E}-8$ & $92-4,56 \mathrm{~A}$ & 1345.06 & 27.5 & $\mathrm{~N}$ & $1.0 \mathrm{E}-6$ \\
\hline $85-6,8$ & 1284.58 & -37.0 & $\mathrm{R}$ & 5.5 E-8 & $92-4,56 \mathrm{~B}$ & 1345.06 & 33.0 & $\mathrm{~N}$ & 2.4 E-6 \\
\hline $86-1,14$ & 1286.14 & -37.6 & REP & 8.2 E-8 & $92-4,140$ & 1345.90 & 26.4 & $\mathrm{~N}$ & $6.0 \mathrm{E}-7$ \\
\hline $86-1,112$ & 1287.12 & -51.4 & $\mathrm{R}$ & $1.9 \mathrm{E}-8$ & $92-5,34$ & 1346.34 & 27.6 & NOP & 7.5 E-7 \\
\hline $86-2,38$ & 1287.88 & -36.8 & REP & $1.2 \mathrm{E}-7$ & $92-5,89$ & 1346.89 & 40.2 & $\mathrm{~N}$ & $1.7 \mathrm{E}-7$ \\
\hline $86-2,124$ & 1288.74 & -38.9 & $\mathrm{R}$ & 8.9 E-8 & $92-5,132$ & 1347.32 & 40.6 & NOP & $6.1 \mathrm{E}-7$ \\
\hline $86-3,28$ & 1289.28 & -43.4 & $\mathrm{R}$ & $5.5 \mathrm{E}-8$ & $92-6,8$ & 1347.58 & 36.6 & NOP & 2.2 E-7 \\
\hline $86-3,114$ & 1290.14 & -28.2 & $\mathrm{R}$ & $6.1 \mathrm{E}-8$ & $92-6,56$ & 1348.06 & 20.7 & INT & $4.9 \mathrm{E}-8$ \\
\hline $86-4,34$ & 1290.89 & -31.4 & $\mathrm{R}$ & 4.4 E- 8 & $93-1,131$ & 1349.31 & 41.3 & NOP & $7.5 \mathrm{E}-8$ \\
\hline $86-5,121$ & 1291.71 & -31.4 & R & $6.9 \mathrm{E}-8$ & $93-2,16$ & 1349.66 & 37.9 & $\mathrm{~N}$ & $4.9 \mathrm{E}-7$ \\
\hline $86-5,6$ & 1292.06 & -40.4 & REP & $5.9 \mathrm{E}-8$ & $93-2,66$ & 1350.16 & 50.0 & NOP & $1.6 \mathrm{E}-8$ \\
\hline $87-1,17$ & 1295.17 & -38.7 & $\mathrm{R}$ & $1.0 \mathrm{E}-7$ & $93-2,131$ & 1350.81 & 31.9 & NOP & 4.5 E-7 \\
\hline $87-1,138$ & 1296.38 & -38.4 & $\mathrm{R}$ & $2.0 \mathrm{E}-7$ & $93-3,29$ & 1351.29 & 40.0 & NOP & 3.2 E-7 \\
\hline $87-2,52$ & 1297.02 & -35.8 & $\mathrm{R}$ & $1.1 \mathrm{E}-7$ & $93-3,127$ & 1352.27 & 33.9 & $\mathrm{~N}$ & 6.4 E-8 \\
\hline $87-2,137$ & 1297.87 & -38.2 & $\mathrm{R}$ & 9.1 E-8 & $93-4,14$ & 1352.64 & 29.4 & $\mathrm{~N}$ & 8.5 E-7 \\
\hline $87-3,34$ & 1298.34 & -34.3 & $\mathrm{R}$ & $1.5 \mathrm{E}-7$ & $93-4,47$ & 1352.97 & 28.6 & NOP & 8.0 E-7 \\
\hline $87-3,130$ & 1299.30 & -37.8 & $\mathrm{R}$ & $1.4 \mathrm{E}-7$ & $94-1,17$ & 1353.67 & 35.2 & $\mathrm{~N}$ & $5.0 \mathrm{E}-7$ \\
\hline $87-4,23$ & 1299.73 & -34.9 & $\mathrm{R}$ & 5.5 E-8 & $94-1,93$ & 1354.43 & 28.8 & $\mathrm{~N}$ & 2.1 E-6 \\
\hline $87-4,122$ & 1300.72 & -42.1 & $\mathrm{R}$ & $1.1 \mathrm{E}-7$ & $94-2,9$ & 1355.09 & 22.7 & NOP & 4.9 E- 6 \\
\hline $87-5,18$ & 1301.18 & -45.6 & $\mathrm{R}$ & $1.4 \mathrm{E}-7$ & $94-2,77$ & 1355.77 & 29.5 & NOP & 2.5 E-6 \\
\hline $87-5,136$ & 1302.36 & 25.6 & $\mathrm{~N}$ & 7.9 E-8 & $94-2,135$ & 1356.35 & 39.5 & NOP & $9.3 \mathrm{E}-7$ \\
\hline $87-6,3$ & 1302.53 & -35.4 & R & 9.4 E-8 & $94-3,46$ & 1356.96 & -28.2 & $\mathrm{R}$ & $2.2 \mathrm{E}-7$ \\
\hline $88-1,17$ & 1304.11 & -18.4 & REP & 3.4 E-8 & $94-3,124$ & 1357.74 & 20.9 & INT & 8.2 E-7 \\
\hline $88-1,07$ & 1305.07 & -34.3 & $\mathrm{R}$ & 2.1 E-7 & $94-4,7$ & 1358.07 & -31.9 & REP & 5.2 E-7 \\
\hline $88-2,16$ & 1305.66 & -42.0 & $\mathrm{R}$ & $8.7 \mathrm{E}-8$ & $94-4,77$ & 1358.77 & -38.1 & $\mathrm{R}$ & $3.3 \mathrm{E}-7$ \\
\hline $88-2,131$ & 1306.81 & -44.1 & $\mathrm{R}$ & 6.4 E-8 & $95-1,15$ & 1362.65 & -43.6 & $\mathrm{R}$ & 7.1 E-7 \\
\hline $88-3,27$ & 1307.27 & -44.8 & $\mathrm{R}$ & 8.7 E-8 & $95-1,71 \mathrm{~A}$ & 1363.21 & -17.2 & $\mathrm{R}$ & $1.3 \mathrm{E}-6$ \\
\hline $83-3,133 \mathrm{~A}$ & 1308.33 & -43.0 & $\mathrm{R}$ & $7.5 \mathrm{E}-8$ & $95-1,71 \mathrm{~B}$ & 1363.21 & -3.6 & INT & $8.8 \mathrm{E}-7$ \\
\hline
\end{tabular}


Appendix B (continued).

\begin{tabular}{|c|c|c|c|c|c|c|c|c|c|}
\hline $\begin{array}{c}\text { Core-Section } \\
\text { (interval in } \mathrm{cm} \text { ) }\end{array}$ & $\begin{array}{l}\text { Sub-bottom } \\
\text { depth } \\
\text { (m) }\end{array}$ & Mean incl. ${ }^{\mathrm{a}}$ & Pol. int. ${ }^{b}$ & $\begin{array}{c}\text { Mean } \\
\text { intensity } \\
\left(\mathrm{emu} / \mathrm{cm}^{3}\right)\end{array}$ & $\begin{array}{c}\text { Core-Section } \\
\text { (interval in cm) }\end{array}$ & $\begin{array}{l}\text { Sub-bottom } \\
\text { depth } \\
\text { (m) }\end{array}$ & Mean incl. ${ }^{a}$ & Pol. int. ${ }^{b}$ & $\begin{array}{c}\text { Mean } \\
\text { intensity } \\
\left(\mathrm{emu} / \mathrm{cm}^{3}\right)\end{array}$ \\
\hline $95-2,65$ & 1364.65 & 22.7 & $\mathrm{~N}$ ? & 7.4 E-7 & $100-1,106$ & 1402.06 & 18.4 & $\mathrm{~N}$ & $1.5 \mathrm{E}-6$ \\
\hline $95-2,120$ & 1365.20 & -37.3 & $\mathrm{R}$ & $1.1 \mathrm{E}-6$ & $100-2,38$ & 1402.88 & 23.0 & NOP & $8.0 \mathrm{E}-7$ \\
\hline $95-3,6$ & 1365.56 & 30.4 & $\mathrm{~N}$ & $1.5 \mathrm{E}-6$ & $100-3,36$ & 1404.36 & 19.3 & $\mathrm{~N}$ & $1.6 \mathrm{E}-6$ \\
\hline $95-3,73$ & 1366.23 & 42.9 & $\mathrm{~N}$ & $5.4 \mathrm{E}-8$ & $100-3,133$ & 1405.33 & 29.1 & $\mathrm{~N}$ & $1.0 \mathrm{E}-6$ \\
\hline $95-3,133$ & 1366.83 & 34.6 & NOP & $7.1 \mathrm{E}-8$ & $100-4,13$ & 1405.63 & 20.9 & $\mathrm{~N}$ & $2.4 \mathrm{E}-6$ \\
\hline $95-4,26$ & 1367.26 & 22.7 & $\mathrm{~N}$ & 7.2 E-7 & $100-4,102$ & 1406.52 & -9.9 & REP & $4.8 \mathrm{E}-7$ \\
\hline $95-4,116$ & 1368.16 & 23.2 & $\mathrm{~N}$ & $1.2 \mathrm{E}-6$ & $101-1,30$ & 1410.30 & 25.8 & $\mathrm{~N}$ & $2.0 \mathrm{E}-6$ \\
\hline $95-5,38$ & 1368.88 & 24.5 & $\mathrm{~N}$ & $4.2 \mathrm{E}-6$ & $101-2,28$ & 1411.78 & -16.2 & $\mathrm{R}$ & $5.6 \mathrm{E}-7$ \\
\hline $96-1,9$ & 1371.59 & 23.5 & $\mathrm{~N}$ & $2.9 \mathrm{E}-6$ & $101-3,42$ & 1413.42 & -0.5 & REP & $1.1 \mathrm{E}-6$ \\
\hline $96-1,106$ & 1372.56 & 23.6 & $\mathrm{~N}$ & $3.3 \mathrm{E}-6$ & $101-3,110$ & 1414.10 & -2.6 & REP & $1.8 \mathrm{E}-6$ \\
\hline $96-2,7$ & 1373.07 & 26.3 & $\mathrm{~N}$ & $1.0 \mathrm{E}-6$ & $101-4,139$ & 1415.89 & -13.8 & $\mathrm{R}$ & $2.0 \mathrm{E}-6$ \\
\hline $96-2,101$ & 1374.01 & -19.2 & $\mathrm{R}$ & $1.3 \mathrm{E}-6$ & $101-5,50$ & 1416.50 & -1.5 & REP & $6.9 \mathrm{E}-7$ \\
\hline $96-3,40$ & 1374.90 & -23.7 & REP & $1.8 \mathrm{E}-7$ & $101-5,133$ & 1417.33 & 13.3 & $\mathrm{R}$ ? & $4.0 \mathrm{E}-7$ \\
\hline $96-3,103$ & 1357.53 & -23.7 & REP & $3.5 \mathrm{E}-7$ & $102-1,39$ & 1419.39 & -10.6 & $\mathrm{R}$ & $2.1 \mathrm{E}-6$ \\
\hline $96-4,14$ & 1376.14 & -20.8 & $\mathrm{R}$ & $2.2 \mathrm{E}-6$ & $102-1,139$ & 1420.39 & -1.5 & REP & $1.8 \mathrm{E}-6$ \\
\hline $96-4,80$ & 1376.80 & -17.6 & R & $3.9 \mathrm{E}-6$ & $102-2,17$ & 1420.67 & 13.7 & INT & $6.8 \mathrm{E}-6$ \\
\hline $96-5,39$ & 1377.89 & -30.7 & REP & $6.7 \mathrm{E}-7$ & $102-2,105$ & 1421.55 & 22.4 & $\mathrm{~N}$ & $7.1 \mathrm{E}-6$ \\
\hline $97-1,20$ & 1380.70 & 10.7 & NOP & $7.4 \mathrm{E}-7$ & $102-3,19$ & 1422.19 & -1.1 & $\mathrm{R}$ ? & $1.2 \mathrm{E}-6$ \\
\hline $97-1,34$ & 1380.84 & 17.8 & NOP & $1.7 \mathrm{E}-6$ & $102-4,21$ & 1423.71 & 10.7 & NOP & $4.8 \mathrm{E}-6$ \\
\hline $98-0,2$ & 1381.02 & 31.6 & $\mathrm{~N}$ & $3.4 \mathrm{E}-6$ & $102-4,98$ & 1424.48 & -5.8 & REP & $1.3 \mathrm{E}-6$ \\
\hline $99-1,21$ & 1395.71 & 22.3 & $\mathrm{~N}$ & $2.3 \mathrm{E}-6$ & $102-5,32$ & 1425.32 & 15.7 & NOP & $1.5 \mathrm{E}-6$ \\
\hline $99-1,91$ & 1396.41 & 29.2 & $\mathrm{~N}$ & $2.1 \mathrm{E}-7$ & $102-5,123$ & 1426.23 & 6.4 & NOP & 9.7 E-6 \\
\hline $99-2,41$ & 1397.41 & 26.3 & $\mathrm{~N}$ & $1.7 \mathrm{E}-6$ & $103-1,16$ & 1428.16 & 22.6 & $\mathrm{~N}$ & $3.9 \mathrm{E}-6$ \\
\hline $99-2,119$ & 1398.19 & 14.7 & $\mathrm{~N}$ & $1.8 \mathrm{E}-6$ & $103-1,71$ & 1428.71 & -6.8 & REP & $1.2 \mathrm{E}-5$ \\
\hline $99-3,67$ & 1399.17 & 23.2 & $\mathrm{~N}$ & $2.3 \mathrm{E}-6$ & $103-1,129$ & 1429.29 & -20.4 & REP & $1.0 \mathrm{E}-7$ \\
\hline $99-4,29$ & 1400.29 & 21.2 & $\mathrm{~N}$ & $1.2 \mathrm{E}-6$ & & & & & \\
\hline
\end{tabular}

${ }_{\mathrm{b}}^{\mathrm{a}}$ Mean incl. = mean inclination of characteristic magnetization.

$\mathrm{b}$ Pol, int, = polarity interpretation: $\mathrm{N}, \mathrm{R}=$ definite normal, reversed polarity; NOP, REP = probable normal, reversed polarity, poor directional stability; N?, R? = uncertain, but possibly normal, reversed; INT $=$ intermediate or indeterminate polarity.

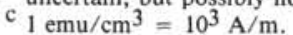

APPENDIX C

Directions of Characteristic Magnetization, DSDP Hole 603B: Early Cretaceous

\begin{tabular}{|c|c|c|c|c|c|c|c|c|c|}
\hline $\begin{array}{l}\text { Core-Section } \\
\text { (interval in } \mathrm{cm} \text { ) }\end{array}$ & Decl. $^{a}$ & Incl. ${ }^{a}$ & Pol, int. ${ }^{b}$ & $\begin{array}{c}\text { Mean }^{\mathrm{c}} \\
\text { intensity } \\
\left(\mathrm{emu} / \mathrm{cm}^{3}\right)\end{array}$ & $\begin{array}{l}\text { Core-Section } \\
\text { (interval in } \mathrm{cm} \text { ) }\end{array}$ & Decl. $^{a}$ & Incl. $^{a}$ & Pol. int. ${ }^{b}$ & $\begin{array}{c}\text { Mean }{ }^{\mathrm{c}} \\
\text { intensity } \\
\left(\mathrm{emu} / \mathrm{cm}^{3}\right)\end{array}$ \\
\hline $40-2,122$ & $338.2^{\circ}$ & $43.6^{\circ}$ & NOR & $7.39 \mathrm{E}-7$ & $45-1,91$ & 8.6 & 25.9 & NOP & 8.55 E-7 \\
\hline $40-4,100$ & 297.1 & 37.9 & NOR & $1.76 \mathrm{E}-6$ & $47-1,8$ & 232.1 & 49.8 & $\mathrm{~N}$ ?? & $5.08 \mathrm{E}-7$ \\
\hline $40-5,29$ & 14.0 & 41.5 & NOR & $3.13 \mathrm{E}-6$ & $49-1,127$ & 162.3 & -21.7 & REP & $5.49 \mathrm{E}-8$ \\
\hline $41-1,80$ & 21.6 & 28.9 & NOR & 2.81 E-5 & $49-2,135$ & 338.2 & 66.0 & NOP & $6.37 \mathrm{E}-7$ \\
\hline $41-2,70$ & 332.1 & 42.3 & NOR & 2.69 E- 5 & $49-3,51$ & 2.0 & 47.9 & NOR & $1.29 \mathrm{E}-7$ \\
\hline $41-3,16$ & 181.8 & -41.0 & REV & $3.15 \mathrm{E}-5$ & $49-3,141$ & 328.0 & 50.6 & NOR & 4.88 E- 8 \\
\hline $41-4,41$ & 33.2 & 49.1 & N?? & 3.06 E-5 & $49-4,23$ & 45.1 & 58.7 & NOR & $1.10 \mathrm{E}-7$ \\
\hline $42-1,56$ & 59.3 & 51.6 & NOR & $2.21 \mathrm{E}-7$ & $49-4,79$ & 137.1 & -31.9 & REV & $1.11 \mathrm{E}-8$ \\
\hline $42-1,86$ & 254.3 & 34.9 & NOR & $7.79 \mathrm{E}-8$ & $49-5,14$ & 304.3 & 68.4 & N?? & $3.26 \mathrm{E}-8$ \\
\hline $42-2,32$ & 13.1 & 40.3 & NOR & 5.95 E-7 & $49-5,83$ & 232.5 & -31.4 & REV & 6.57 E-8 \\
\hline $42-2,119$ & 28.5 & 33.3 & NOR & $5.25 \mathrm{E}-7$ & $50-1,122$ & 250.2 & -44.0 & REV & $2.43 \mathrm{E}-8$ \\
\hline $42-3,109$ & 14.9 & 42.9 & NOR & $2.08 \mathrm{E}-7$ & $51-1,108$ & 323.7 & -33.8 & REP & $3.02 \mathrm{E}-8$ \\
\hline $42-3,131$ & 7.0 & 40.5 & NOR & $3.28 \mathrm{E}-7$ & $51-1,128$ & 58.3 & 26.3 & NOR & 2.54 E- 8 \\
\hline $42-4,107$ & 352.2 & 39.3 & NOR & $7.09 \mathrm{E}-7$ & $51-2,18$ & 90.4 & -33.6 & REV & $1.39 \mathrm{E}-8$ \\
\hline $42-4,116$ & 359.9 & 38.6 & NOR & 4.34 E-7 & $51-2,73$ & 226.1 & -16.3 & REP & 9.46 E-9 \\
\hline $42-5,37$ & 3.3 & 25.8 & NOR & $1.54 \mathrm{E}-7$ & $51-2,123$ & 50.3 & 67.3 & NOP & 2.77 E-8 \\
\hline $42-5,101$ & 51.8 & 45.6 & NOR & $6.23 \mathrm{E}-7$ & $51-3,55$ & 118.2 & 34.8 & NOR & $4.28 \mathrm{E}-8$ \\
\hline $42-6,49$ & 21.9 & 29.7 & NOR & 2.24 E- 6 & $51-3,144$ & 189.3 & -11.2 & REV & $3.09 \mathrm{E}-8$ \\
\hline $43-1,111$ & 13.4 & 43.1 & NOR & 2.35 E-5 & $51-4,36$ & 227.5 & 0.1 & INT & 3.47 E-8 \\
\hline $43-2,66$ & 330.2 & 47.0 & NOR & 9.98 E-6 & $51-4,74$ & 133.9 & 36.9 & NOR & $1.20 \mathrm{E}-8$ \\
\hline $43-2,122$ & 325.5 & 53.2 & NOR & 2.11 E-5 & $51-4,96$ & 119.3 & 66.3 & NOP & $2.50 \mathrm{E}-8$ \\
\hline $43-3,53$ & 348.4 & 46.6 & NOR & 3.17 E-5 & $51-4,127$ & 197.7 & -7.9 & R?? & $7.48 \mathrm{E}-8$ \\
\hline $43-3,122$ & 20.4 & 43.6 & NOR & 3.00 E-5 & $51-5,6$ & 248.1 & 63.3 & NOR & 9.73 E-9 \\
\hline $43-4,13$ & 344.7 & 36.3 & NOR & 2.09 E-5 & $51-5,48$ & 254.7 & 52.5 & NOR & $1.83 \mathrm{E}-8$ \\
\hline $43-4,52$ & 15.4 & 42.9 & NOR & $2.15 \mathrm{E}-5$ & $51-6,59$ & 173.7 & 51.7 & NOR & $2.42 \mathrm{E}-8$ \\
\hline $43-5,38$ & 344.6 & 29.1 & NOR & $1.39 \mathrm{E}-5$ & $51-6,108$ & 96.4 & -54.3 & REV & $2.20 \mathrm{E}-8$ \\
\hline $43-5,113$ & 358.7 & 39.6 & NOR & $1.03 \mathrm{E}-5$ & $52-1,33$ & 190.0 & 17.8 & R?? & $9.99 \mathrm{E}-8$ \\
\hline $43-6,44$ & 11.2 & 52.0 & NOR & 2.73 E-6 & $52-1,67$ & 75.5 & 40.8 & NOR & 3.60 E-8 \\
\hline $44-1,76$ & 336.3 & 28.1 & NOR & $1.08 \mathrm{E}-7$ & $52-1,121$ & 53.4 & 39.9 & NOP & $4.75 \mathrm{E}-8$ \\
\hline $44-1,119$ & 166.5 & 53.9 & N?? & $6.93 \mathrm{E}-8$ & $52-2,10$ & 151.8 & 54.7 & INT & 7.52 E-9 \\
\hline $44-2,33$ & 95.2 & 38.4 & N?? & $2.96 \mathrm{E}-7$ & $52-2,88$ & 57.6 & 33.2 & INT & 7.57 E-9 \\
\hline $44-2,127$ & 63.2 & 16.8 & N?? & $1.80 \mathrm{E}-7$ & $52-2,125$ & 204.2 & 24.4 & NOP & $2.87 \mathrm{E}-8$ \\
\hline $44-3,45$ & 37.0 & 50.3 & NOP & $9.40 \mathrm{E}-8$ & $52-3,4$ & 297.6 & 60.7 & NOR & $2.39 \mathrm{E}-8$ \\
\hline $44-3,112$ & 7.1 & 29.3 & NOR & $2.19 \mathrm{E}-7$ & $52-3,67$ & 80.8 & 52.7 & NOR & 8.99 E- 8 \\
\hline $44-4,76$ & 349.0 & 40.4 & NOR & 1.93 E-7 & $52-3,132$ & 333.1 & 26.4 & NOR & 1.91 E-7 \\
\hline
\end{tabular}


Appendix C (continued).

\begin{tabular}{|c|c|c|c|c|c|c|c|c|c|}
\hline $\begin{array}{l}\text { Core-Section } \\
\text { (interval in } \mathrm{cm} \text { ) }\end{array}$ & Decl. $^{\mathrm{a}}$ & Incl. $^{\mathrm{a}}$ & Pol. int. ${ }^{b}$ & $\begin{array}{c}\text { Mean }{ }^{\mathrm{c}} \\
\text { intensity } \\
\left(\mathrm{emu} / \mathrm{cm}^{3}\right)\end{array}$ & $\begin{array}{l}\text { Core-Section } \\
\text { (interval in } \mathrm{cm} \text { ) }\end{array}$ & Decl. $^{a}$ & Incl. $^{a}$ & Pol. int. ${ }^{b}$ & $\begin{array}{c}\text { Mean }^{\mathrm{c}} \\
\text { intensity } \\
\left(\mathrm{emu} / \mathrm{cm}^{3}\right)\end{array}$ \\
\hline $52-4,34$ & 242.2 & 58.5 & N?? & $1.09 \mathrm{E}-8$ & $61-6,36$ & 171.0 & -28.8 & REV & 5.24 E-8 \\
\hline $52-4,100$ & 306.5 & 68.5 & NOP & 2.54 E-8 & $61-6,91$ & 182.7 & -30.4 & REV & $1.85 \mathrm{E}-8$ \\
\hline $52-4,140$ & 48.0 & 4.4 & INT & $2.49 \mathrm{E}-8$ & $62-1,41$ & 206.1 & 7.7 & REP & $1.63 \mathrm{E}-8$ \\
\hline $52-5,26$ & 227.9 & 36.2 & NNP & $6.38 \mathrm{E}-8$ & $62-1,96$ & 227.0 & -1.0 & REP & $1.04 \mathrm{E}-8$ \\
\hline $52-5,81$ & 203.5 & 83.0 & INT & $1.23 \mathrm{E}-7$ & $62-1,140$ & 225.1 & -51.9 & REV & $2.62 \mathrm{E}-8$ \\
\hline $52-5,121$ & 342.9 & 51.4 & NOR & $6.93 \mathrm{E}-8$ & $62-259$ & 331.8 & -0.6 & REV & $4.19 \mathrm{E}-8$ \\
\hline $52-6,71$ & 85.8 & 17.7 & $\mathrm{R}$ ?? & 4.50 E-8 & $62-2,102$ & 195.0 & -21.3 & REP & $1.39 \mathrm{E}-8$ \\
\hline $52-6,143$ & 350.1 & 51.0 & NOR & $4.93 \mathrm{E}-8$ & $62-3,50$ & 192.4 & -15.2 & REV & 4.84 E- 8 \\
\hline $53-1,80$ & 10.4 & 65.9 & NOP & $2.34 \mathrm{E}-8$ & $62-3,94$ & 160.3 & -36.3 & REV & $6.88 \mathrm{E}-8$ \\
\hline $53-1,139$ & 216.8 & 30.0 & N?? & 1.45 E-8 & $62-3,130$ & 222.1 & -36.2 & REV & 4.41 E- 8 \\
\hline $53-2,14$ & 186.2 & 49.3 & N?? & $2.56 \mathrm{E}-8$ & $62-4,14$ & 176.7 & -44.8 & REV & $5.38 \mathrm{E}-8$ \\
\hline $53-2,64$ & 187.2 & 54.5 & NOP & $1.11 \mathrm{E}-7$ & $62-4,61$ & 209.6 & -31.9 & REV & 5.43 E-8 \\
\hline $53-2,109$ & 302.5 & 60.8 & NOR & $1.00 \mathrm{E}-8$ & $62-4,94$ & 136.3 & -17.1 & REV & 4.42 E- 8 \\
\hline $53-3,26$ & 256.1 & 53.1 & NOR & 2.11 E-8 & $62-5,39$ & 178.3 & 57.0 & NOR & 5.91 E-8 \\
\hline $53-4,94$ & 318.9 & 78.1 & NOP & $2.12 \mathrm{E}-8$ & $62-5,78$ & 134.5 & -50.5 & REV & $3.54 \mathrm{E}-8$ \\
\hline $53-4,143$ & 256.5 & 49.2 & NOP & 8.61 E-9 & $62-5,112$ & 30.6 & 49.9 & NOR & $6.20 \mathrm{E}-8$ \\
\hline $53-5,8$ & 288.0 & 44.1 & NOR & 4.06 E-8 & $63-1,67$ & 284.9 & -34.7 & REV & 3.72 E-8 \\
\hline $53-5,83$ & 260.7 & -56.8 & REV & 9.66 E-9 & $63-1,120$ & 207.9 & -48.4 & REV & 9.21 E-8 \\
\hline $53-5,127$ & 101.2 & 42.4 & NOR & 7.70 E-8 & $63-2,13$ & 126.3 & -19.4 & REV & $1.90 \mathrm{E}-8$ \\
\hline $53-6,60$ & 86.3 & 56.8 & REP & $1.40 \mathrm{E}-8$ & $63-2,69$ & 181.7 & -26.0 & REV & $2.83 \mathrm{E}-8$ \\
\hline $54-2,8$ & 248.7 & -20.7 & REV & $2.40 \mathrm{E}-8$ & $63-2,124$ & 181.8 & -28.4 & REV & 7.41 E-8 \\
\hline $54-2,141$ & 225.5 & 15.8 & INT & $1.20 \mathrm{E}-7$ & $63-3,13$ & 112.2 & -7.9 & REV & $1.31 \mathrm{E}-8$ \\
\hline $54-3,51$ & 248.9 & -38.2 & REV & $1.13 \mathrm{E}-7$ & $63-3,68$ & 221.4 & -8.7 & REV & 3.03 E-8 \\
\hline $54-4,30$ & 143.0 & -1.5 & REP & $3.60 \mathrm{E}-8$ & $63-3,120$ & 159.9 & -25.9 & REV & $1.12 \mathrm{E}-8$ \\
\hline $54-5,16$ & 131.6 & -54.4 & REV & $4.98 \mathrm{E}-8$ & $63-4,13$ & 114.5 & 53.5 & INT & $2.29 \mathrm{E}-8$ \\
\hline $54-5,125$ & 12.6 & 61.7 & NOR & $6.45 \mathrm{E}-8$ & $63-4,67$ & 45.4 & 72.7 & NOR & 2.77 E-8 \\
\hline $55-1,38$ & 164.3 & 57.3 & NOR & $2.11 \mathrm{E}-8$ & $63-4,115$ & 341.4 & 45.0 & NOR & $6.96 \mathrm{E}-8$ \\
\hline $55-1,129$ & 293.9 & 19.0 & N?? & $1.34 \mathrm{E}-8$ & $63-5,12$ & 345.2 & 48.7 & NOR & $5.75 \mathrm{E}-8$ \\
\hline $55-3,49$ & 136.0 & 29.4 & NOP & $2.88 \mathrm{E}-8$ & $63-5,67$ & 233.5 & 40.0 & NOR & $1.79 \mathrm{E}-7$ \\
\hline $55-3,109$ & 110.7 & -27.7 & REV & 7.06 E-8 & $63-5,113$ & 163.3 & 45.3 & NOR & 7.12 E- 8 \\
\hline $55-4,55$ & 174.5 & -22.8 & REV & 2.77 E-8 & $63-6,11$ & 248.4 & 57.0 & NOR & $1.02 \mathrm{E}-7$ \\
\hline $55-5,29$ & 195.5 & -28.7 & REP & $2.27 \mathrm{E}-8$ & $63-6,65$ & 43.7 & 47.1 & NOR & 6.34 E-8 \\
\hline $55-5,114$ & 236.1 & -65.4 & REV & $3.43 \mathrm{E}-8$ & $63-6,111$ & 6.6 & 50.0 & NOR & 8.69 E- 8 \\
\hline $56-2,103$ & 11.0 & 39.4 & NOR & $1.14 \mathrm{E}-7$ & $64-1,21$ & 44.1 & 42.5 & NOR & $4.00 \mathrm{E}-8$ \\
\hline $56-3,104$ & 351.0 & 29.4 & NOR & $1.01 \mathrm{E}-7$ & $64-1,89$ & 2.4 & 43.8 & NOR & $1.22 \mathrm{E}-7$ \\
\hline $56-4,127$ & 20.9 & 43.5 & NOR & 8.13 E-8 & $64-1,117$ & 39.4 & -41.8 & REV & 2.47 E-8 \\
\hline $57-1,73$ & 337.5 & 47.1 & NOR & $1.16 \mathrm{E}-7$ & $64-2,29$ & 154.6 & -20.1 & REV & 3.74 E-8 \\
\hline $57-2,77$ & 105.3 & 21.1 & N?? & $1.58 \mathrm{E}-7$ & $64-2,76$ & 134.1 & -25.2 & REV & $1.05 \mathrm{E}-8$ \\
\hline $57-2,125$ & 74.0 & 51.0 & NOR & 7.96 E-8 & $64-2,114$ & 153.8 & 55.5 & NOR & 2.63 E-8 \\
\hline $57-5,48$ & 352.2 & 26.4 & NOR & $6.66 \mathrm{E}-8$ & $64-3,13$ & 91.8 & -33.5 & REP & $1.80 \mathrm{E}-8$ \\
\hline $57-6,141$ & 71.0 & -67.3 & R?? & 1.32 E- 6 & $64-3,62$ & 76.4 & -46.8 & REV & 3.62 E-8 \\
\hline $58-3,88$ & 2.7 & 51.2 & NOR & 7.67 E-8 & $64-3,124$ & 204.3 & -43.0 & REV & 3.03 E-8 \\
\hline $58-3,118$ & 351.7 & 39.7 & NOP & 2.97 E-8 & $64-4,34$ & 55.0 & -47.3 & REV & $1.22 \mathrm{E}-7$ \\
\hline $58-4,48$ & 347.2 & 41.0 & NOR & $1.31 \mathrm{E}-7$ & $64-4,77$ & 290.1 & -42.8 & REP & $2.60 \mathrm{E}-8$ \\
\hline $58-5,77$ & 339.5 & 57.8 & NOR & $1.56 \mathrm{E}-8$ & $64-4,113$ & 337.8 & -40.8 & REV & $5.78 \mathrm{E}-8$ \\
\hline $58-5,125$ & 318.2 & 55.9 & NOR & $4.38 \mathrm{E}-8$ & $64-5,29$ & 38.3 & -33.8 & REV & 1.34 E-8 \\
\hline $58-6,43$ & 320.6 & 69.2 & NOR & 9.01 E-9 & $64-5,81$ & 162.7 & -10.6 & REP & $1.03 \mathrm{E}-8$ \\
\hline $59-1,35$ & 355.9 & 53.9 & NOR & 3.77 E-8 & $64-5,113$ & 176.0 & -41.7 & REV & $4.53 \mathrm{E}-8$ \\
\hline $59-1,136$ & 2.4 & 52.7 & NOR & $1.23 \mathrm{E}-8$ & $64-6,12$ & 23.3 & 63.7 & N?? & $1.34 \mathrm{E}-8$ \\
\hline $59-2,11$ & 49.5 & 60.7 & NOR & 6.01 E-8 & $65-1,30$ & 67.7 & 39.9 & INT & 3.90 E-9 \\
\hline $59-2,93$ & 1.8 & 53.6 & NOR & $1.05 \mathrm{E}-7$ & $65-1,101$ & 295.7 & 63.8 & INT & 8.66 E-9 \\
\hline $59-3,9$ & 10.7 & 84.6 & NOR & $1.45 \mathrm{E}-8$ & $65-1,132$ & 250.0 & -27.5 & REP & $1.36 \mathrm{E}-8$ \\
\hline $59-3,133$ & 348.8 & 51.2 & NOR & 3.09 E-8 & $65-3,55$ & 203.0 & -24.6 & REV & $9.75 \mathrm{E}-8$ \\
\hline $59-4,2$ & 185.8 & -31.9 & $\mathrm{R}$ ?? & 5.30 E-9 & $65-3,105$ & 192.8 & -26.1 & REV & 2.95 E-8 \\
\hline $59-4,49$ & 176.1 & -34.3 & REV & 2.44 E- 8 & $65-4,17$ & 178.2 & -26.7 & REV & $1.17 \mathrm{E}-8$ \\
\hline $59-5,36$ & 171.1 & -36.6 & REV. & $2.69 \mathrm{E}-8$ & $65-4,78$ & 357.3 & 38.8 & N?? & 9.10 E-9 \\
\hline $59-5,92$ & 227.5 & -27.8 & $\mathrm{R}$ ?? & 8.78 E-9 & $65-4,138$ & 189.6 & 49.3 & INT & 9.33 E-9 \\
\hline $59-5,122$ & 330.9 & 24.5 & N?? & 4.57 E-8 & $65-5,17$ & 281.6 & -42.2 & REP & $4.18 \mathrm{E}-8$ \\
\hline $60-2,26$ & 327.1 & 21.4 & N?? & 9.39 E-9 & $65-5,88$ & 129.4 & -47.5 & REV & 7.61 E-8 \\
\hline $60-3,31$ & 141.2 & -25.9 & R?? & $1.67 \mathrm{E}-8$ & $65-5,131$ & 196.7 & -15.5 & REV & 7.39 E-9 \\
\hline $60-3,58$ & 351.2 & 38.6 & INT & 6.81 E-9 & $65-6,16$ & 121.1 & -40.7 & REV & $3.32 \mathrm{E}-8$ \\
\hline $60-4,60$ & 204.7 & -33.2 & REV & $1.42 \mathrm{E}-7$ & $65-6,43$ & 268.7 & 74.7 & $\mathrm{~N}$ ?? & $1.26 \mathrm{E}-8$ \\
\hline $60-4,108$ & 6.3 & 55.0 & NOR & 5.67 E-8 & $66-1,33$ & 326.6 & 52.0 & NOR & $4.72 \mathrm{E}-8$ \\
\hline $61-1,20$ & 102.1 & 1.8 & R?? & 3.74 E-8 & $66-1,66$ & 328.5 & 49.2 & NOR & $3.70 \mathrm{E}-8$ \\
\hline $61-1,95$ & 165.9 & -22.2 & REV & $6.90 \mathrm{E}-8$ & $66-1,118$ & 17.6 & 50.4 & NOR & $2.49 \mathrm{E}-8$ \\
\hline $61-2,4$ & 4.9 & 31.5 & NOR & $1.75 \mathrm{E}-8$ & $66-2,9$ & 329.1 & 63.6 & NOR & $3.03 \mathrm{E}-8$ \\
\hline $61-3,15$ & 242.3 & -21.7 & REV & $2.61 \mathrm{E}-8$ & $66-2,62$ & 330.5 & 48.0 & NOR & 8.95 E-8 \\
\hline $61-3,67$ & 317.6 & 61.2 & NOP & 7.35 E-9 & $66-2,117$ & 353.4 & 61.4 & NOR & $6.43 \mathrm{E}-8$ \\
\hline $61-3,125$ & 59.0 & 63.9 & NOR & $1.19 \mathrm{E}-8$ & $66-3,15$ & 9.9 & 60.3 & NOR & 3.69 E-8 \\
\hline $61-4,33$ & 224.6 & 59.2 & NOR & $2.19 \mathrm{E}-8$ & $66-3,80$ & 352.2 & 48.2 & NOR & 7.99 E-8 \\
\hline $61-4,96$ & 314.9 & 49.8 & NOR & $1.85 \mathrm{E}-8$ & $66-3,144$ & 331.9 & 58.9 & NOR & 1.46 E-8 \\
\hline $61-4,141$ & 7.6 & 66.6 & NOR & 3.04 E-8 & $66-4,56$ & 16.1 & 47.0 & NOR & $7.19 \mathrm{E}-8$ \\
\hline $61-5,9$ & 320.4 & 59.2 & INT & $1.38 \mathrm{E}-8$ & $66-4,95$ & 349.2 & 60.9 & NOR & $5.59 \mathrm{E}-8$ \\
\hline $61-5,64$ & 194.9 & 2.8 & REP & $1.20 \mathrm{E}-8$ & $66-4,128$ & 333.7 & 59.4 & NOR & 4.94 E- 8 \\
\hline $61-5,135$ & 162.8 & -25.0 & REV & $2.25 \mathrm{E}-8$ & $66-5,36$ & 32.7 & 60.4 & NOR & $9.13 \mathrm{E}-8$ \\
\hline
\end{tabular}


Appendix C (continued).

\begin{tabular}{|c|c|c|c|c|c|c|c|c|c|}
\hline $\begin{array}{l}\text { Core-Section } \\
\text { (interval in } \mathrm{cm} \text { ) }\end{array}$ & Decl. $^{a}$ & Incl. $^{a}$ & Pol. int. & $\begin{array}{c}\text { Mean }^{\mathrm{c}} \\
\text { intensity } \\
\left(\mathrm{emu} / \mathrm{cm}^{3}\right)\end{array}$ & $\begin{array}{l}\text { Core-Section } \\
\text { (interval in } \mathrm{cm} \text { ) }\end{array}$ & Decl. $^{\mathrm{a}}$ & Incl. $^{\mathrm{a}}$ & Pol. int. ${ }^{b}$ & $\begin{array}{c}\text { Mean }^{\mathrm{c}} \\
\text { intensity } \\
\left(\mathrm{emu} / \mathrm{cm}^{3}\right)\end{array}$ \\
\hline $66-5,89$ & 13.8 & 59.6 & NOR & 2.84 E-8 & $73-5,109$ & 208.6 & -40.3 & REV & $4.29 \mathrm{E}-8$ \\
\hline $66-5,139$ & 19.4 & 61.2 & NOR & $6.86 \mathrm{E}-8$ & $73-5,139$ & 193.3 & -31.4 & REP & 7.32 E-9 \\
\hline $66-6,15$ & 24.3 & 57.7 & NOR & 7.44 E-8 & $74-1,65$ & 328.7 & -14.3 & REP & 5.30 E-9 \\
\hline $66-6,37$ & 5.8 & 59.5 & NOR & 5.87 E-8 & $74-1,124$ & 48.1 & 69.3 & NOR & $4.29 \mathrm{E}-8$ \\
\hline $67-1,8$ & 30.7 & 63.0 & NOR & $7.13 \mathrm{E}-8$ & $74-2,46$ & 333.0 & 72.1 & NOR & 1.42 E-8 \\
\hline $67-1,73$ & 270.2 & 83.9 & $\mathrm{R}$ ?? & $1.42 \mathrm{E}-8$ & $74-2,101$ & 81.1 & 74.1 & NOP & $2.50 \mathrm{E}-8$ \\
\hline $67-2,79$ & 55.1 & -48.4 & REV & $3.61 \mathrm{E}-8$ & $74-2,135$ & 36.5 & 54.0 & NOP & 1.99 E-8 \\
\hline $67-2,126$ & 195.0 & -30.0 & REV & $4.10 \mathrm{E}-8$ & $74-3,29$ & 16.2 & 64.2 & NOR & $1.26 \mathrm{E}-8$ \\
\hline $67-3,11$ & 189.1 & -11.4 & REP & 1.44 E-8 & $74-3,73$ & 118.9 & 18.1 & INT & 8.47 E-9 \\
\hline $67-3,122$ & 249.3 & -29.1 & REV & 2.63 E-8 & $74-3,142$ & 37.5 & 57.9 & NOR & $2.45 \mathrm{E}-8$ \\
\hline $67-4,68$ & 126.2 & -43.7 & REV & $1.00 \mathrm{E}-7$ & $74-4,26$ & 17.7 & 68.9 & NOR & 2.12 E- 8 \\
\hline $67-4,99$ & 131.6 & -22.9 & REV & $3.04 \mathrm{E}-8$ & $74-4,88$ & 340.1 & 52.0 & NOR & $2.34 \mathrm{E}-8$ \\
\hline $67-4,142$ & 84.6 & -20.1 & REV & $2.48 \mathrm{E}-8$ & $74-4,130$ & 348.6 & 55.9 & NOR & $3.53 \mathrm{E}-8$ \\
\hline $67-5,43$ & 166.8 & -16.0 & REV & $1.13 \mathrm{E}-7$ & $74-5,21$ & 13.0 & 55.1 & NOR & $2.38 \mathrm{E}-8$ \\
\hline $67-5,121$ & 45.3 & -46.1 & REV & 1.94 E-8 & $74-5,103$ & 342.6 & 60.5 & NOR & 4.35 E- 8 \\
\hline $67-6,109$ & 133.6 & -47.0 & REP & 6.72 E-9 & $74-5,144$ & 19.1 & 64.8 & NOR & $2.58 \mathrm{E}-8$ \\
\hline $68-1,53$ & 183.0 & -29.2 & REV & 1.34 E-7 & $74-6,42$ & 7.7 & 52.6 & NOR & 5.72 E- 8 \\
\hline $68-1,113$ & 202.6 & -35.8 & REP & $1.10 \mathrm{E}-7$ & $74-6,89$ & 348.2 & 60.2 & NOR & $2.56 \mathrm{E}-8$ \\
\hline $68-2,33$ & 68.3 & -16.1 & REP & $1.63 \mathrm{E}-8$ & $74-6,126$ & 17.1 & 61.4 & NOR & $5.20 \mathrm{E}-8$ \\
\hline $68-2,108$ & 169.7 & 63.1 & INT & 5.93 E-9 & $74-7,28$ & 339.2 & 63.5 & NOR & $3.24 \mathrm{E}-8$ \\
\hline $68-3,11$ & 317.2 & -36.9 & REV & 8.18 E- 8 & $75-1,14$ & 346.0 & 61.5 & NOR & 2.34 E-8 \\
\hline $68-3,63$ & 156.9 & -43.3 & REV & $1.63 \mathrm{E}-8$ & $75-1,65$ & 350.1 & 59.8 & NOR & 5.04 E-8 \\
\hline $68-3,143$ & 197.5 & 62.6 & N?? & 1.49 E-8 & $75-1,119$ & 323.7 & 31.1 & NOR & $4.29 \mathrm{E}-8$ \\
\hline $68-4,48$ & 228.8 & -43.9 & REV & $2.71 \mathrm{E}-8$ & $75-2,22$ & 330.3 & 41.5 & NOR & $2.71 \mathrm{E}-8$ \\
\hline $68-4,105$ & 149.3 & 54.4 & INT & 2.42 E-8 & $75-2,75$ & 350.0 & 62.0 & NOR & $2.59 \mathrm{E}-8$ \\
\hline $68-4,139$ & 346.1 & 47.5 & NOR & $3.36 \mathrm{E}-8$ & $75-2,136$ & 175.4 & -39.1 & REV & $1.00 \mathrm{E}-8$ \\
\hline $68-5,75$ & 341.0 & 65.9 & NOR & $4.91 \mathrm{E}-8$ & $75-3,5$ & 355.9 & 57.8 & NOR & $1.84 \mathrm{E}-8$ \\
\hline $68-5,131$ & 312.3 & 44.7 & NOR & 2.50 E- 8 & $75-3,50$ & 206.2 & 8.4 & R?? & $1.02 \mathrm{E}-8$ \\
\hline $68-6,39$ & 52.4 & 63.0 & NOR & 2.12 E-8 & $75-3,129$ & 135.9 & 59.4 & NOP & $1.21 \mathrm{E}-8$ \\
\hline $69-1,9$ & 349.1 & 58.7 & NOR & $2.39 \mathrm{E}-8$ & $75-4,13$ & 208.2 & 82.3 & N?? & 9.31 E-9 \\
\hline $69-1,62$ & 353.6 & 49.1 & NOR & $9.82 \mathrm{E}-8$ & $75-4,49$ & 300.2 & 50.8 & NOR & $1.97 \mathrm{E}-8$ \\
\hline $69-1,121$ & 68.9 & 80.8 & INT & 8.43 E-9 & $75-4,106$ & 10.7 & 75.9 & NOP & 9.70 E-9 \\
\hline $69-2,26$ & 38.4 & 43.0 & NOR & $2.36 \mathrm{E}-8$ & $75-5,10$ & 348.5 & 67.1 & NOR & $2.67 \mathrm{E}-8$ \\
\hline $69-2,68$ & 15.5 & 52.0 & NOR & 8.92 E- 8 & $75-5,71$ & 1.0 & 48.5 & NOR & $1.71 \mathrm{E}-8$ \\
\hline $69-2,109$ & 349.3 & 63.8 & NOR & 9.25 E-8 & $76-1,7$ & 186.5 & -55.6 & REV & $2.91 \mathrm{E}-8$ \\
\hline $69-3,4$ & 52.1 & 49.0 & NOR & $2.70 \mathrm{E}-8$ & $76-1,54$ & 182.9 & -63.4 & REP & $1.77 \mathrm{E}-8$ \\
\hline $69-3,60$ & 44.3 & 77.4 & NOP & $3.18 \mathrm{E}-8$ & $76-1,113$ & 94.3 & -77.0 & REP & $1.20 \mathrm{E}-8$ \\
\hline $69-3,114$ & 349.1 & 54.6 & NOR & $4.83 \mathrm{E}-8$ & $76-2,14$ & 37.5 & 81.3 & NOR & $2.10 \mathrm{E}-8$ \\
\hline $69-4,8$ & 6.9 & 66.7 & NOR & $1.45 \mathrm{E}-8$ & $76-2,64$ & 341.1 & 66.7 & NOR & 5.51 E-8 \\
\hline $69-4,62$ & 311.9 & 38.5 & NOP & 4.41 E-9 & $76-2,116$ & 9.7 & 72.1 & NOP & $2.49 \mathrm{E}-8$ \\
\hline $69-4,113$ & 202.5 & -46.6 & REV & 1.72 E-8 & $76-3,16$ & 269.2 & 65.1 & NOR & $1.44 \mathrm{E}-8$ \\
\hline $69-5,16$ & 144.5 & -28.8 & REV & 2.46 E- 8 & $76-3,65$ & 256.9 & 71.0 & NOP & 3.36 E-8 \\
\hline $69-5,75$ & 271.9 & -23.3 & R?? & 3.68 E- 8 & $76-3,116$ & 347.0 & 72.1 & NOP & 1.71 E-8 \\
\hline $69-5,126$ & 67.4 & 50.6 & NOR & 9.92 E-8 & $76-4,16$ & 19.2 & 82.9 & NOP & 8.76 E-9 \\
\hline $69-6,21$ & 50.6 & 54.0 & NOR & $6.98 \mathrm{E}-8$ & $76-4,62$ & 323.3 & 71.7 & NOR & $2.71 \mathrm{E}-8$ \\
\hline $69-6,74$ & 264.0 & 48.1 & NOR & $6.20 \mathrm{E}-8$ & $76-4,114$ & 219.1 & 85.0 & N?? & $1.59 \mathrm{E}-8$ \\
\hline $69-6,135$ & 341.3 & 53.6 & NOR & 6.55 E-8 & $76-5,13$ & 321.9 & 72.2 & NOR & $1.58 \mathrm{E}-8$ \\
\hline $69-7,31$ & 11.3 & 62.8 & NOR & 6.32 E- 8 & $76-5,77$ & 49.7 & 72.4 & NOR & $1.38 \mathrm{E}-8$ \\
\hline $70-1,23$ & 117.4 & 75.6 & NOR & 4.73 E-8 & $77-1,20$ & 346.4 & 79.1 & NOR & 2.30 E- 8 \\
\hline $70-1,69$ & 45.6 & 59.0 & NOR & 4.96 E-8 & $77-1,86$ & 66.1 & 79.0 & NOR & 1.44 E-8 \\
\hline $70-1,120$ & 58.3 & 2.9 & INT & 4.96 E-8 & $77-1,140$ & 311.5 & 66.5 & NOR & 9.65 E-9 \\
\hline $70-2,46$ & 95.5 & 52.7 & NOP & $4.70 \mathrm{E}-8$ & $77-2,39$ & 303.3 & 69.5 & NOR & $1.05 \mathrm{E}-8$ \\
\hline $70-2,78$ & 252.7 & -31.6 & REP & 4.68 E-9 & $77-2,86$ & 315.1 & 69.5 & NOR & $1.12 \mathrm{E}-8$ \\
\hline $70-3,33$ & 253.2 & 63.1 & NOR & 8.79 E-9 & $7-72,133$ & 3.3 & 64.7 & NOR & 9.00 E-9 \\
\hline $70-3,79$ & 8.2 & 55.7 & NOR & 8.19 E-8 & $77-3,26$ & 73.3 & 63.6 & NOR & 1.55 E-8 \\
\hline $70-3,130$ & 349.7 & 59.2 & NOP & $2.86 \mathrm{E}-8$ & $77-3,91$ & 36.5 & 82.8 & NOP & $1.08 \mathrm{E}-8$ \\
\hline $70-4,32$ & 26.6 & 43.7 & NOR & $3.13 \mathrm{E}-8$ & $77-3,130$ & 9-1 & -0.4 & $\mathrm{R}$ ?? & $1.20 \mathrm{E}-8$ \\
\hline $70-4,114$ & 356.0 & 51.1 & NOR & $6.97 \mathrm{E}-8$ & $77-4,131$ & 355.2 & 69.0 & NOR & 1.35 E-8 \\
\hline $70-5,50$ & 343.7 & 53.3 & NOR & 4.64 E-8 & $77-4,132$ & 339.2 & 42.3 & NOP & 6.19 E-9 \\
\hline $70-5,129$ & 153.0 & 40.4 & NOR & $1.50 \mathrm{E}-8$ & $77-5,24$ & 34.1 & 61.0 & NOR & 9.77 E-9 \\
\hline $71-2,15$ & 184.8 & -9.7 & REP & $1.24 \mathrm{E}-8$ & $77-5,72$ & 166.8 & 59.1 & N?? & 7.45 E-9 \\
\hline $71-4,19$ & 339.7 & 67.8 & NOR & $2.38 \mathrm{E}-8$ & $77-5,116$ & 322.5 & 63.8 & NOR & 9.72 E-9 \\
\hline $71-4,130$ & 341.6 & 63.8 & NOR & $3.00 \mathrm{E}-8$ & $77-6,22$ & 87.0 & 83.6 & INT & $1.51 \mathrm{E}-8$ \\
\hline $71-5,43$ & 350.0 & 60.9 & NOR & 2.47 E-8 & $77-6,55$ & 144.0 & 76.6 & NOP & 8.19 E-9 \\
\hline $71-5,99$ & 309.5 & 50.6 & NOR & 2.55 E-8 & $77-6,127$ & 274.4 & 63.9 & NOR & $1.22 \mathrm{E}-8$ \\
\hline $71-6,49$ & 32.2 & 57.8 & NOP & $3.40 \mathrm{E}-8$ & $77-7,25$ & 347.6 & 77.4 & NOP & 6.63 E-9 \\
\hline $71-6,103$ & 340.6 & 58.1 & NOR & 4.97 E-8 & $77-7,45$ & 7.7 & 59.8 & NOR & 6.85 E-9 \\
\hline $73-1,24$ & 137.0 & 67.2 & NOP & 9.88 E-9 & $78-1,18$ & 352.9 & 3.1 & INT & 3.40 E-9 \\
\hline $73-1,84$ & 186.3 & 9.6 & INT & $1.59 \mathrm{E}-8$ & $78-1,87$ & 49.3 & 45.1 & NOR & 8.18 E-9 \\
\hline $73-1,144$ & 161.8 & -34.3 & REV & $1.93 \mathrm{E}-8$ & $78-1,122$ & 35.3 & 64.8 & NOR & 9.28 E-9 \\
\hline $73-2,36$ & 343.4 & -22.7 & INT & 5.75 E-9 & $78-2,14$ & 327.7 & 68.8 & NOP & 1.75 E-8 \\
\hline $73-2,125$ & 163.9 & 26.4 & N?? & $1.36 \mathrm{E}-8$ & $78-2,67$ & 293.9 & 13.2 & N?? & 2.46 E- 8 \\
\hline $73-3,45$ & 144.6 & -17.1 & REV & $2.35 \mathrm{E}-8$ & $78-2,120$ & 295.6 & 56.4 & NOR & $1.17 \mathrm{E}-8$ \\
\hline $73-3,111$ & 179.1 & -18.5 & REV & 7.35 E-9 & $78-3,15$ & 20.6 & 39.7 & NOR & $1.34 \mathrm{E}-8$ \\
\hline $73-4,103$ & 225.5 & -77.6 & INT & 5.31 E-9 & $78-3,76$ & 343.0 & 63.4 & NOR & $1.61 \mathrm{E}-8$ \\
\hline $73-5,29$ & 195.4 & -42.6 & REV & $1.20 \mathrm{E}-8$ & $78-3,120$ & 94.2 & 63.2 & NOR & $1.52 \mathrm{E}-8$ \\
\hline
\end{tabular}


Appendix C (continued).

\begin{tabular}{|c|c|c|c|c|c|c|c|c|c|}
\hline $\begin{array}{l}\text { Core-Section } \\
\text { (interval in } \mathrm{cm} \text { ) }\end{array}$ & Decl. $^{a}$ & Incl. $^{a}$ & Pol. int. ${ }^{b}$ & $\begin{array}{c}\text { Mean }{ }^{\mathrm{c}} \\
\text { intensity } \\
\left(\mathrm{emu} / \mathrm{cm}^{3}\right)\end{array}$ & $\begin{array}{l}\text { Core-Section } \\
\text { (interval in } \mathrm{cm} \text { ) }\end{array}$ & Decl. $^{a}$ & Incl. $^{a}$ & Pol. int. ${ }^{b}$ & $\begin{array}{c}\text { Mean }^{\mathrm{c}} \\
\text { intensity } \\
\left(\mathrm{emu} / \mathrm{cm}^{3}\right)\end{array}$ \\
\hline $78-4,25$ & 322.8 & 70.4 & NOP & 6.92 E-9 & $80-5,131$ & 160.4 & 28.3 & $\mathrm{R}$ ?? & 6.33 E-9 \\
\hline $78-4,42$ & 34.3 & 61.2 & NOP & 9.28 E-9 & $80-6,15$ & 253.4 & 36.2 & INT & 6.22 E-9 \\
\hline $78-4,85$ & 344.2 & 33.9 & NOP & $1.24 \mathrm{E}-8$ & $80-6,45$ & 250.6 & -15.7 & REP & $1.46 \mathrm{E}-8$ \\
\hline $79-1,13$ & 39.7 & 64.4 & NOR & 2.55 E-8 & $81-1,11$ & 96.6 & -37.3 & REV & 8.82 E-9 \\
\hline $79-1,58$ & 41.7 & 72.4 & NOP & 8.10 E-9 & $81-1,73$ & 316.2 & 59.3 & NOR & $2.33 \mathrm{E}-8$ \\
\hline $79-1,123$ & 231.3 & 26.2 & INT & 4.95 E-9 & $81-1,121$ & 66.9 & 53.0 & NOR & $3.58 \mathrm{E}-8$ \\
\hline $79-2,31$ & 353.8 & 64.3 & NOR & $1.16 \mathrm{E}-8$ & $81-2,10$ & 121.0 & 86.7 & N?? & 8.72 E- 8 \\
\hline $79-2,76$ & 162.2 & 25.2 & INT & 7.14 E-9 & $81-2,75$ & 355.4 & 45.6 & N?? & $5.25 \mathrm{E}-8$ \\
\hline $79-2,121$ & 326.0 & 5.7 & INT & $1.01 \mathrm{E}-8$ & $81-2,120$ & 257.9 & 78.2 & R?? & $2.72 \mathrm{E}-8$ \\
\hline $79-3,25$ & 300.4 & 66.0 & NOP & 4.93 E-9 & $81-3,12$ & 122.3 & 57.4 & NOR & 5.33 E-8 \\
\hline $79-3,75$ & 158.3 & 4.9 & INT & 1.46 E-8 & $81-3,76$ & 14.6 & 43.1 & NOR & 4.27 E-8 \\
\hline $79-3,128$ & 13.8 & 18.1 & INT & $1.61 \mathrm{E}-8$ & $81-3,114$ & 6.3 & 59.4 & NOR & $6.71 \mathrm{E}-8$ \\
\hline $79-4,27$ & 195.2 & 61.2 & INT & 8.83 E-9 & $81-4,12$ & 197.3 & 69.8 & NOR & $4.33 \mathrm{E}-8$ \\
\hline $79-4,75$ & 222.9 & 21.6 & INT & $1.07 \mathrm{E}-8$ & $81-4,77$ & 0.5 & 45.1 & NOP & $9.41 \mathrm{E}-8$ \\
\hline $79-4,122$ & 89.3 & 7.8 & INT & 8.76 E-9 & $81-4,125$ & 18.1 & 53.7 & NOR & $9.20 \mathrm{E}-8$ \\
\hline $79-5,27$ & 300.1 & 49.1 & NOP & 5.03 E-9 & $81-5,7$ & 10.5 & 52.4 & NOR & $6.66 \mathrm{E}-8$ \\
\hline $79-5,76$ & 24.1 & 52.8 & NOP & $1.15 \mathrm{E}-8$ & $81-5,76$ & 48.4 & 51.6 & NOR & $1.46 \mathrm{E}-7$ \\
\hline $79-5,120$ & 50.8 & 57.3 & NOP & 5.62 E-9 & $81-5,121$ & 340.0 & 57.9 & NOR & $1.38 \mathrm{E}-7$ \\
\hline $79-6,27$ & 128.7 & 56.9 & N?? & 5.50 E-9 & $81-6,22$ & 97.6 & 61.6 & NOP & 8.21 E-8 \\
\hline $79-6,70$ & 177.8 & 58.4 & N?? & 6.69 E-9 & $81-6,45$ & 51.4 & 50.3 & NOR & $2.09 \mathrm{E}-7$ \\
\hline $79-6,126$ & 1.3 & 80.9 & N?? & $1.23 \mathrm{E}-8$ & $82-1,19$ & 359.1 & 65.2 & NOR & $2.69 \mathrm{E}-8$ \\
\hline $80-1,24$ & 40.6 & 40.8 & NOP & $1.20 \mathrm{E}-8$ & $82-1,70$ & 349.5 & 62.2 & NOR & $5.09 \mathrm{E}-8$ \\
\hline $80-1,68$ & 246.3 & -22.2 & REP & $1.37 \mathrm{E}-8$ & $82-1,125$ & 350.9 & 45.7 & NOR & 9.97 E-8 \\
\hline $80-1,142$ & 171.0 & 60.7 & N?? & 9.29 E-9 & $82-2,19$ & 352.5 & 53.6 & NOR & $1.11 \mathrm{E}-7$ \\
\hline $80-2,22$ & 143.3 & 42.8 & $\mathrm{R}$ ?? & $1.83 \mathrm{E}-8$ & $82-2,61$ & 352.7 & 60.6 & NOR & 8.65 E-8 \\
\hline $80-2,65$ & 304.5 & 61.9 & NOR & $1.90 \mathrm{E}-8$ & $82-2,125$ & 232.9 & -37.9 & REV & $3.32 \mathrm{E}-8$ \\
\hline $80-2,138$ & 320.1 & 56.3 & NOR & 1.67 E-8 & $82-3,12$ & 349.3 & 51.7 & NOR & $1.33 \mathrm{E}-7$ \\
\hline $80-3,9$ & 247.7 & 25.1 & INT & $1.96 \mathrm{E}-8$ & $82-3,64$ & 343.4 & 61.0 & NOR & 5.17 E-8 \\
\hline $80-3,86$ & 101.1 & 36.8 & INT & 3.74 E-8 & $82-3,122$ & 10.7 & 56.4 & NOR & 7.66 E-8 \\
\hline $80-3,125$ & 19.5 & 44.6 & NOR & 2.03 E-8 & $82-4,5$ & 350.7 & 47.9 & NOR & $6.20 \mathrm{E}-8$ \\
\hline $80-4,17$ & 268.4 & -17.5 & REP & 2.98 E-8 & $82-4,66$ & 148.6 & 17.4 & REP & $2.28 \mathrm{E}-8$ \\
\hline $80-4,60$ & 111.0 & -16.5 & REV & $1.55 \mathrm{E}-8$ & $82-4,129$ & 173.3 & -11.5 & REV & 1.47 E-8 \\
\hline $80-4,117$ & 183.8 & -6.2 & REP & 8.05 E-9 & $82-5,22$ & 172.3 & -26.0 & REV & $2.40 \mathrm{E}-8$ \\
\hline $80-5,7$ & 338.8 & 77.1 & INT & 1.07 E-8 & $82-5,90$ & 221.5 & -35.5 & REP & $2.32 \mathrm{E}-8$ \\
\hline $80-5,64$ & 231.3 & -17.5 & $\mathrm{R}$ ?? & $1.98 \mathrm{E}-8$ & & & & & \\
\hline
\end{tabular}

${ }^{\text {a }}$ Decl. = declination of characteristic magnetization. Not all samples are oriented, however. Incl. = inclination of characteristic magnetization. Directions are before correcting for the deviation of Hole 603B from vertical.

${ }^{\mathrm{b}}$ Pol. int. = polarity interpretation: NOR, REV = definite normal, reversed polarity, NOP, REP = probable normal, reversed polarity, poor di-

rectional stability; N??, R?? = uncertain, but possibly normal, reversed polarity; INT = intermediate or indeterminate polarity.

c $1 \mathrm{emu} / \mathrm{cm}^{3}=10^{3} \mathrm{~A} / \mathrm{m}$. 